UNIVERSIDADE DE BRASÍLIA- UNB

Faculdade de Economia, Administração e Contabilidade - FACE

Departamento de Economia

Mestrado em Economia do Setor Público - MESP

VIRGÍLIO DE MATOS SANTOS CASTELO BRANCO

ANÁLISE DE IMPACTO REGULATÓRIO DOS REQUISITOS DE PROJETO DE AERÓDROMOS NO BRASIL: UMA ANÁLISE ECONÔMICA E APLICAÇÃO AO CASO DO AEROPORTO DE CONGONHAS 


\section{ANÁLISE DE IMPACTO REGULATÓRIO DOS REQUISITOS DE PROJETO DE AERÓDROMOS NO BRASIL: UMA ANÁLISE ECONÔMICA E APLICAÇÃO AO CASO DO AEROPORTO DE CONGONHAS}

Dissertação de Mestrado apresentada ao Departamento de Economia da Universidade de Brasília, como parte dos requisitos necessários à obtenção do título de Mestre em Economia do Setor Público.

Orientador: Prof. Dr. César Costa Alves de Mattos 


\section{BRASÍLIA-DF}

Brasília-DF, 28 de setembro de 2016.

Ficha Catalográfica

Castelo Branco, V. M. S

Análise de Impacto Regulatório dos Requisitos de Projeto de Aeródromos no Brasil: Uma Análise Econômica e Aplicação ao Caso do Aeroporto de Congonhas

Orientador: Prof. Dr. César Costa Alves de Mattos

Brasília: UnB, 2016. 96 p.

Dissertação (mestrado) - Universidade de Brasília.

Faculdade de Economia, Administração e Contabilidade.

Mestrado em Economia do Setor Público.

1. Análise de Impacto Regulatório; 2. Análise de Custo-Benefício; 3. Valor Estatístico da Vida; 4. Infraestrutura Aeroportuária; 5. Aeroporto de Congonhas

\section{REFERÊNCIA BIBLIOGRÁFICA}

CASTELO BRANCO, Virgílio de Matos Santos. Análise de Impacto Regulatório dos Requisitos de Projeto de Aeródromos no Brasil: Uma Análise Econômica e Aplicação ao Caso do Aeroporto de Congonhas. Dissertação de Mestrado em Economia do Setor Público, Programa Mestrado em Economia do Setor Público, Universidade de Brasília, Brasília, DF, 2016. 


\section{VIRGÍLIO DE MATOS SANTOS CASTELO BRANCO}

\section{ANÁLISE DE IMPACTO REGULATÓRIO DOS REQUISITOS DE PROJETO DE AERÓDROMOS NO BRASIL: UMA ANÁLISE ECONÔMICA E APLICAÇÃO AO CASO DO AEROPORTO DE CONGONHAS}

Esta Dissertação foi julgada adequada para obtenção do Título de "Mestre em Economia do Setor Público", e aprovada em sua forma final pelo Programa Mestrado em Economia do Setor Público.

Brasília, DF. 28 de setembro de 2016.

Prof. Dr. Vander Mendes Lucas,

Coordenador do Curso

\section{Banca Examinadora:}

Prof. Dr. César Costa Alves de Mattos, Orientador - MESP/UnB

Prof. Dr. Vander Mendes Lucas, Membro Interno - MESP/UnB

Dr. Daniel Rodrigues Aldigueri, Membro Externo - Agência Nacional de Aviação Civil

Prof. Dr. Rafael Terra de Menezes, Membro Suplente - MESP/UnB 
Dedico este trabalho de Dissertação de Mestrado à minha família, que sempre semeou e cultivou em mim a importância da educação para o desenvolvimento pessoal, profissional e humano. 


\section{AGRADECIMENTOS}

À Agência Nacional de Aviação Civil, por proporcionar o desenvolvimento profissional e acadêmico de seus servidores.

Ao ex-Diretor Presidente da Agência Nacional de Aviação Civil, Marcelo Pacheco dos Guaranys, aos seus Assessores, em especial Camilo Antônio de Paula Baldy, à Diretoria Colegiada da ANAC e ao Superintendente de Infraestrutura Aeroportuária Fabio Faizi Rahnemay Rabbani, por acreditarem da importância desta e de outras iniciativas de capacitação para a Agência, sem os quais este projeto não teria sido possível.

Aos caros amigos Marcelo Bálbio Moraes e Indio Artiaga do Brasil Rabelo, por todo o companheirismo demonstrado ao longo do curso.

A todos os colegas da $8^{a}$ turma do Mestrado em Economia do Setor Público da UnB, que elevaram o nível do Mestrado, seja pelas fantásticas discussões e conversas sobre temas afetos à economia brasileira, seja mostrando a capacidade intelectual e dedicação que os servidores públicos podem apresentar.

Aos professores do MESP, que compartilharam conosco seus conhecimentos acadêmicos e experiências no Setor Público.

Ao Prof. Dr. César Costa Alves de Mattos, Consultor Legislativo da Câmara dos Deputados, pela precisa orientação para o desenvolvimento desta dissertação.

Ao amigo Dr. Manuel Ayres Jr., pelo seu contínuo trabalho na promoção de uma Aviação Civil mais segura e pelo apoio na elaboração deste trabalho.

Aos colegas e amigos da Agência Nacional de Aviação Civil, em especial da Superintendência de Infraestrutura Aeroportuária, pelo afinco com que trabalham em prol da segurança da Aviação Civil Brasileira.

À minha noiva, Teresa Gardenia Pereira Braga, pelo carinho, companheirismo e compreensão, fundamentais para o êxito deste e de outros projetos em minha vida.

À minha família, base da minha formação pessoal e profissional, que transmitiu a importância da educação na formação do caráter humano.

A Deus de amor, por todas as graças, bem como pelas dificuldades que são postas em nossas vidas junto com a força e determinação necessárias para enfrentá-las, sem as quais não sairíamos do lugar. 
"Educação é uma descoberta progressiva de nossa própria ignorância."

Voltaire 


\title{
RESUMO
}

\section{Análise de Impacto Regulatório dos Requisitos de Projeto de Aeródromos no Brasil: Uma Análise Econômica e Aplicação ao Caso do Aeroporto de Congonhas}

\author{
Autor: Virgílio de Matos Santos Castelo Branco
}

Orientador: Prof. Dr. César Costa Alves de Mattos

\section{Programa de Mestrado em Economia do Setor Público}

\section{Brasília, Setembro de 2016.}

Este trabalho visa a avaliar economicamente a necessidade de adequação das Infraestruturas Aeroportuárias Brasileiras aos requisitos técnicos de Projeto de Aeródromos desenvolvidos pela Organização de Aviação Civil Internacional (OACI) e estabelecidos no Brasil pela Agência Nacional de Aviação Civil (ANAC). Para isso, foi realizada uma revisão bibliográfica sobre Análise de Impacto Regulatório, em especial da Análise de CustoBenefício, metodologia que se mostrou a mais apropriada para avaliar se a adequação das infraestruturas resultaria à sociedade benefícios suficientes para justificar os custos que seriam impostos. Na sequência, realizou-se uma revisão bibliográfica sobre o Valor da Vida Humana, que se concluiu ser o valor ótimo que a sociedade estaria disposta a pagar para a redução dos riscos à vida, cujo estabelecimento se faz necessário para constituição dos corretos incentivos para se evitar que as mortes ocorram. Com base na revisão bibliográfica, calculou-se o Valor Estatístico da Vida (VSL) para o passageiro da Aviação Civil Brasileira como 5,1 milhões de reais para o final de 2015, bem como os valores de 4,1 e 8,0 milhões de reais para a condução de análises de sensibilidade. A metodologia proposta foi aplicada ao Estudo de Caso da adequação do Aeroporto de Congonhas aos requisitos técnicos contidos do Regulamento Brasileiro de Aviação Civil - RBAC 154. Estimou-se que o risco de excursões laterais (veeroff) no Aeroporto de Congonhas é 3,2 x 10 $0^{-7}$, o que através de uma curva nula de crescimento de suas operações leva a um acidente esperado a cada 17 anos. A Análise de Custo-Benefício da adequação do aeroporto com a construção de uma Pista de Pouso e Decolagem central mostrou que os benefícios esperados da adequação superam os custos a serem incorridos, com uma Relação de Benefício-Custo entre 3,4 a 7,9. Concluiu-se que a manutenção da infraestrutura em não-conformidade às normas técnicas com o nível de operação atual existente no aeroporto não é a solução ótima para o bem-estar social, devendo ser estudadas outras possíveis alternativas para a adequação da Infraestrutura de Congonhas. O Estudo de Caso demonstrou que é exequível e apropriada a condução de uma Análise de Custo-Benefício no processo de tomada de decisão da Agência de intervir em um Aeroporto e determinar a adequação de sua infraestrutura ou de isentá-lo do cumprimento de requisitos normativos através de uma análise econômica robusta que leva à maximização do bem-estar social.

Palavras chaves: Análise de Impacto Regulatório, Análise de Custo-Benefício, Valor Estatístico da Vida, Infraestrutura Aeroportuária, Aeroporto de Congonhas. 


\section{ABSTRACT \\ Regulatory Impact Analysis of the Aerodrome Design Requirements in Brazil: An Economic Analysis and A Case Study of Congonhas Airport}

Author: Virgílio de Matos Santos de Matos Santos Castelo Branco

Supervisor: Prof. Dr. César Costa Alves de Mattos

Master Program in Public Economics

\section{Brasília, September of 2016.}

This work aims to economically assess the need to adapt the Brazilian Airport Infrastructure to the technical requirements for Aerodromes Design developed by the International Civil Aviation Organization (ICAO) and established in Brazil by the Civil Aviation Authority (ANAC). For this, a literature review on Regulatory Impact Analysis was carried out, in particular the Cost-Benefit Analysis, methodology that was shown the most appropriate to assess whether the adequation of the infrastructure would result to society sufficient benefits to justify the costs that would be imposed. Following, it was carried out a literature review on the Value of Life that concluded to be the optimal value that society is willing to pay to reduce the risk to life, which is necessary for the establishment of the correct incentives to prevent deaths. Through this literature review, the Value of Statistical Life (VSL) for the Brazilian Civil Aviation passenger was calculated as 5.1 million brazilian reals for the end of 2015, as well as the values of 4.1 and 8.0 million brazilian reals to conduct sensitivity analysis. The proposed methodology was applied to the case study of the adequation of Congonhas Airport to the technical requirements of the Brazilian Civil Aviation Regulation RBAC 154. It was estimated that the risk of veer-off at Congonhas Airport is 3,2 x $10^{-7}$, which through a zero growth curve of airport operations leads to an expected accident every 17 years. The Cost-Benefit Analysis of the airport adequation with the construction of a new Central Runway shows that the expected benefits outweigh the costs that would be incurred with a benefit-cost ratio between 3.4 to 7.9. It was concluded that the maintenance of infrastructure in non-compliance with technical standards and the current operation level at the airport is not the optimal solution for the social welfare, and other possible alternatives should be studied for the adequation of Infrastructure. Through the case study, it was shown that is feasible and suitable to conduct a Cost-Benefit Analysis in the Agency's decision-making process to intervene in an Airport and determine the adequation of its infrastructure or exempt the compliance with regulatory requirements through a robust economic analysis that leads to the maximization of social welfare.

Key words: Regulatory Impact Analysis, Cost-Benefit Analysis, Value of Statistical Life, Airport Infrastructure, Congonhas Airport. 


\section{LISTA DE FIGURAS}

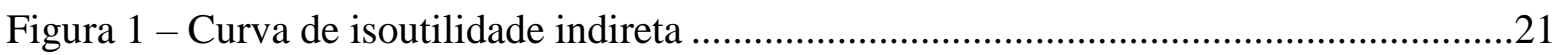

Figura 2 - Processo de transferência do VSL em três etapas ..............................................29

Figura 3 - Fotografia Aérea do Aeroporto de Congonhas ...................................................32

Figura 4 - Pátio principal do Aeroporto de Congonhas antes e depois da expansão de 2003

Figura 5 - Croqui de aproximação com procedimento de aproximação perdida e obstáculos

Figura 6 - Ábaco utilizado para estimar o risco de acidente durante o sobrevoo para aeroporto do código de referência de aeródromo $4 \mathrm{C}$ e aproximação precisão categoria I.....40 Figura 7 - Modelo de Probabilidade de excursão lateral em duas etapas

Figura 8 - Distribuição dos riscos das operações de decolagem do Aeroporto de Congonhas

Figura 9 - Distribuição dos riscos das operações de pouso do Aeroporto de Congonhas .....49

Figura 10 - Pista de Pouso e Decolagem Central proposta para o Aeroporto de Congonhas55

Figura 11 - Custos esperados Cenário Atual e Cenário Adequação da Infraestrutura. 60

Figura 12 - Fluxo de Caixa descontado da adequação da infraestrutura em contrapartida ao cenário atual

Figura 13 - Fluxo de Caixa descontado acumulado da adequação da infraestrutura em contrapartida ao cenário atual.

Figura 14 - Custos Diretos esperados Cenário Atual e Cenário Adequação da Infraestrutura

Figura 15 - Fluxo de Caixa descontado da adequação da infraestrutura em contrapartida ao cenário atual (ACB Parcial)

Figura 16 - Fluxo de Caixa descontado acumulado da adequação da infraestrutura em contrapartida ao cenário atual (ACB Parcial). 


\section{LISTA DE TABELAS}

Tabela 1 - Aeroportos mais antigos do Brasil com operação regular.... 3

Tabela 2 - Histórico de emendas do Anexo 14 à Convenção de Chicago ................................3

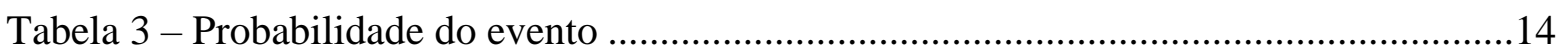

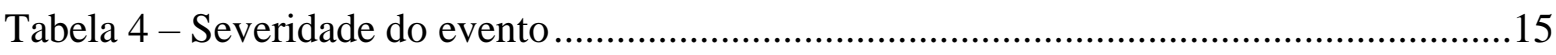

Tabela 5 - Transferência do VSL do passageiro dos EUA para o Brasil ...............................30

Tabela 6 - Transferência do VSL do passageiro da Europa para o Brasil .............................30

Tabela 7 - VSL do Passageiro Regular da Aviação Civil Brasileira .....................................31

Tabela 8 - Separação entre as Pistas de Táxi paralelas e a Pista de Pouso Principal.............34

Tabela 9 - Incidentes e acidentes aeronáuticos em Congonhas com excursão de pista..........35

Tabela 10 - Risco de colisão no sobrevoo para a Pista 17R/35L do Aeroporto de Congonhas

Tabela 11 - Coeficientes das variáveis independentes da regressão logística de probabilidade de excursão lateral

Tabela 12 - Definição das variáveis do modelo de probabilidade de excursão lateral 43

Tabela 13 - Coeficientes do modelo de probabilidade de localização.

Tabela 14 - Ajuste das aeronaves não constantes do Apêndice F do ACRP 51

Tabela 15 - Probabilidade de excursões laterais para o Aeroporto de Congonhas. 48

Tabela 16 - Probabilidade de acidente no Aeroporto de Congonhas associado à separação das Pistas de Táxi paralelas .48

Tabela 17 - Tempo esperado para um acidente associado à separação entre a pista de pouso e decolagem e as pistas de táxi paralelas no Aeroporto de Congonhas.

Tabela 18 - Aeronave mais utilizada pelas empresas aéreas de transporte regular de passageiros em Congonhas

Tabela 19 - Danos às aeronaves e mortes por severidade do acidente aeronáutico...............51

Tabela 20 - Preço das aeronaves novas..........................................................................52

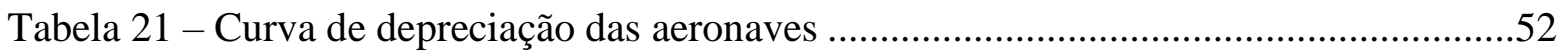

Tabela 22 - Idade média da frota das aeronaves das empresas de transporte regular de passageiros

Tabela 23 - Fatias de Mercado das empresas de transporte regular de passageiros no Aeroporto de Congonhas 
Tabela 24 - Custo Direto do acidente aeronáutico catastrófico no Aeroporto de Congonhas

Tabela 25 - Custo esperado para um acidente aeronáutico catastrófico em Congonhas .......55

Tabela 26 - Custo dos sistemas de pista estimados para as Concessões Aeroportuárias.......56

Tabela 27 - Probabilidade de acidente no Aeroporto de Congonhas associada à separação

das Pistas de Táxi paralelas com a adequação da infraestrutura

Tabela 28 - Tempo esperado para um acidente associado à separação entre a pista de pouso e decolagem e as pistas de táxi paralelas em Congonhas com a adequação da infraestrutura

Tabela 29 - Probabilidade de acidente durante a fase de obras no Aeroporto de Congonhas associado à separação das Pistas de Táxi paralelas 


\section{LISTA DE QUADROS}

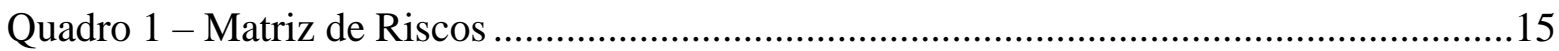

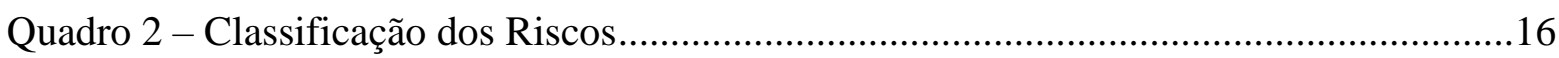

Quadro 3 - Análise de Sensibilidade da ACB ................................................................62

Quadro 4 - Análise de Sensibilidade da ACB Parcial............................................................65 


\section{LISTA DE ABREVIATURAS}

ACB Análise de Custo-Benefício

ACE Analise de Custo-Efetividade

ACRP Airport Cooperative Research Program

ADG Aerodrome Design Group

AIR Análise de Impacto Regulatório

AMD Análise Multicritério à Decisão

ANAC Agência Nacional de Aviação Civil

AR

Análise de Risco

BIMTRA Banco de Informações de Movimento de Tráfego Aéreo

CACI Convenção de Aviação Civil Internacional

CENIPA Centro de Investigação e Prevenção de Acidentes Aeronáuticos

CRM Collision Risk Model

EASA European Aviation Safety Agency

EMAS Engineered Material Arresting System

Eurocontrol European Organization for the Safety of Air Navigation

EVTEA Estudo de Viabilidade Técnica, Econômica e Ambiental

FAA Federal Aviation Admisntration

Hotran Horário de Transporte

ILS Sistema de Aproximação por Instrumento

INCC Índice Nacional da Construção Civil

IPCA Índice Nacional de Preços ao Consumidor Amplo

LDVO Landing veer-off

ME Modelagem de Escolha

METAR Meteorological Aerodrome Report

OACI Organização de Aviação Civil Internacional

OCDE Organização para a Cooperação e Desenvolvimento Econômico

PD Preferências Declaradas

PPD Pista de Pouso e Decolagem

PPP Paridade do Poder de Compra

PR Preferências Reveladas 
RBAC Regulamento Brasileiro de Aviação Civil

RESA Áreas de Segurança de Fim de Pista

SARPs Standards and Recommended Practices

TIR Taxa Interna de Retorno

TLS Target Level of Safety

TMS Taxa Marginal de Substituição

TOVO Takeoff veer-off

VC Valoração Contingenciada

VPL Valor Presente Líquido

VSI Value of Statistical Injury

VSL Value of Statistical Life

WTA Willingness to Accept

WTP Willingness to Pay 


\section{SUMÁRIO}

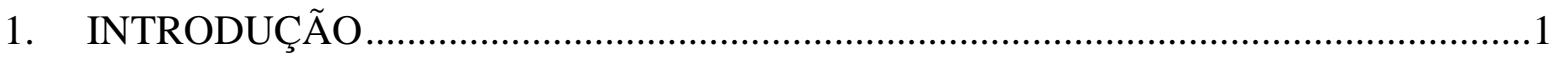

1.1. Evolução das Normas Técnicas e da Infraestrutura Aeroportuária Brasileira ...........2

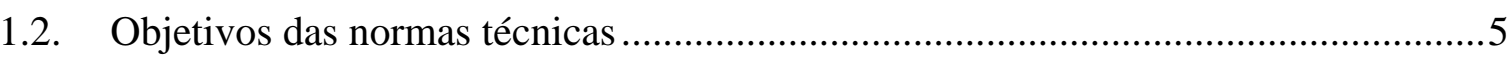

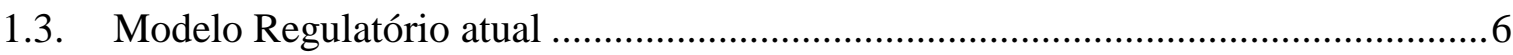

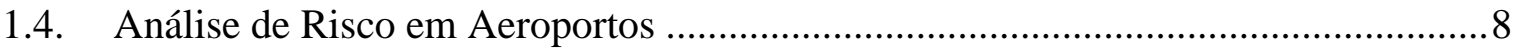

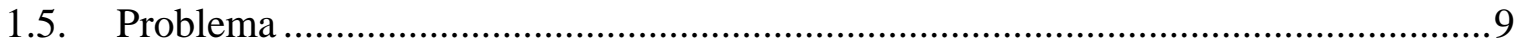

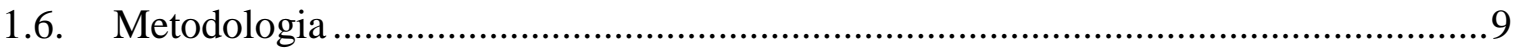

2. ANÁLISE DE IMPACTO REGULATÓRIO ............................................................ 10

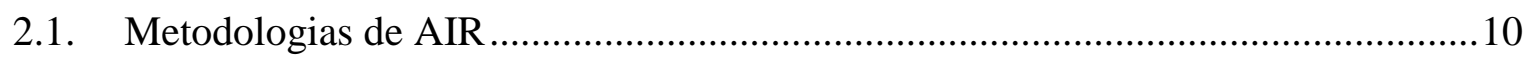

2.1.1. Análise de Custo-Benefício ..........................................................................11

2.1.2. Analise de Custo-Efetividade .................................................................... 12

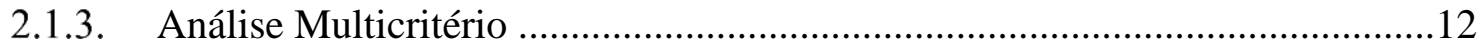

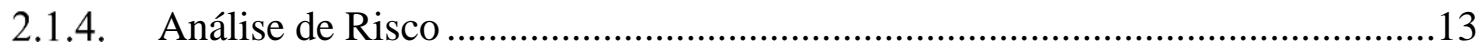

2.2. Utilização de AIR na Aviação Civil ......................................................................

2.2.1. AIR na Organização de Aviação Civil Internacional ......................................16

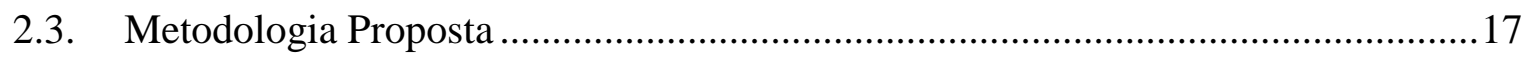

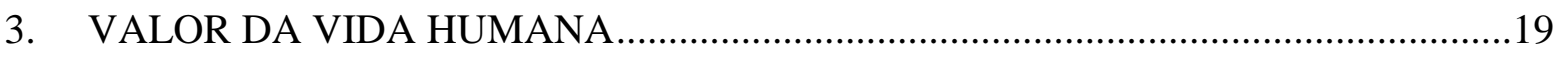

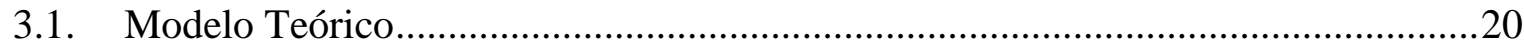

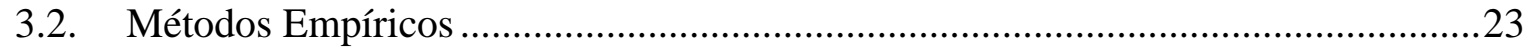

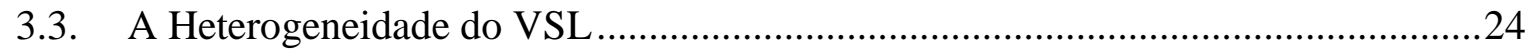

3.3.1. Resultados dos trabalhos de Preferências Reveladas .....................................24

3.3.2. Resultados dos trabalhos de Preferências Declaradas ......................................25

3.4. Organização para a Cooperação e Desenvolvimento Econômico ............................26

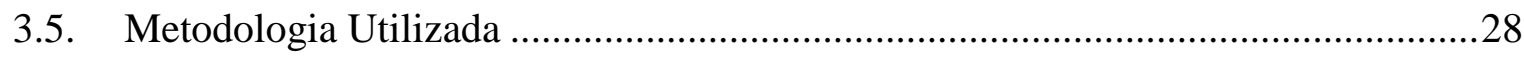

4. ANÁLISE DE CUSTO-BENEFÍCIO DA ADEQUAÇÃO DO AEROPORTO DE

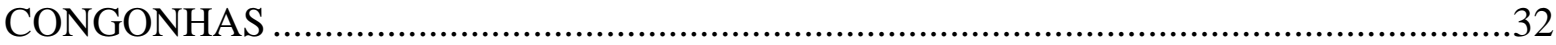

4.1. Principais incidentes e acidentes no Aeroporto de Congonhas e suas

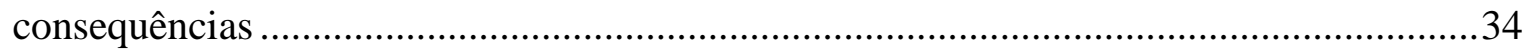

4.2. Quantificação do risco operacional com a infraestrutura existente .........................37

4.2.1. Modelo para o risco de acidente durante o sobrevoo ......................................38

4.2.2. Modelo para o risco de acidente devido a excursões laterais (veer-off) ............41 
4.2.3. Risco total associados às pistas de táxi paralelas ...........................................48

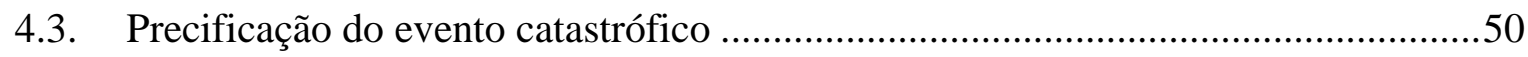

4.3.1. Custos Diretos do Acidente Aeronáutico ........................................................51

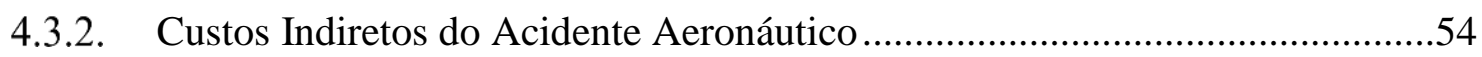

4.3.1. Custos Total do Acidente Aeronáutico..............................................................55

4.4. Estimativa do custo para adequação do aeroporto aos requisitos de projeto ............55

4.5. Quantificação do risco operacional com a adequação da infraestrutura aos

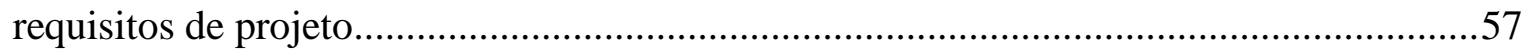

4.6. Análise de custo-benefício da adequação da infraestrutura.....................................58

4.6.1. Análise de Custo-Benefício .............................................................................59

4.6.1. Análise de Custo-Benefício Parcial ................................................................63

4.6.2. Conclusões do Estudo de Caso ........................................................................66

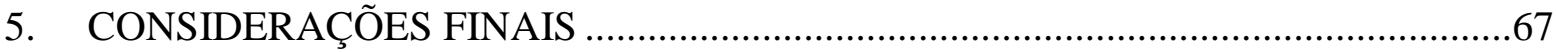

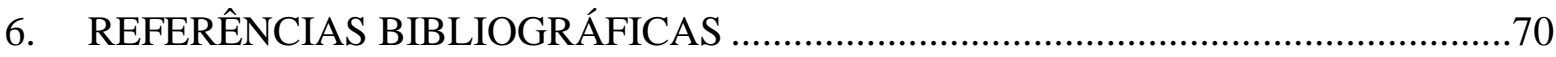

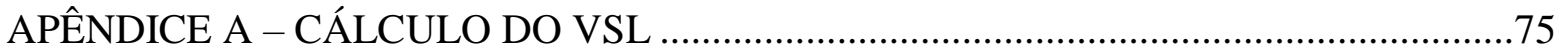

APÊNDICE B - FLUXO DE CAIXA MARGINAL DA ANÁLISE DE CUSTO-

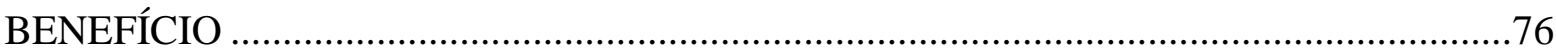




\section{INTRODUÇÃO}

A Infraestrutura Aeroportuária Brasileira enfrenta dois grandes desafios: a expansão da sua capacidade e a garantia da segurança dos passageiros. Enquanto o primeiro tema possui grande repercussão em diversos segmentos da sociedade, o segundo só ganha destaque quando da ocorrência de um acidente aeronáutico. Todavia, são necessários esforços e investimentos para elevar o nível de segurança operacional de alguns aeroportos brasileiros.

A Aviação Civil possui, no Brasil e no mundo, elevados índices de segurança, muito em parte devido ao setor ser fortemente regulamentado e padronizado.

Com a rápida expansão do Transporte Aéreo na primeira metade do século XIX, ao final da Segunda Guerra Mundial, a comunidade internacional identificou a necessidade do desenvolvimento de normas, princípios e padrões para regular o setor visando à garantia da segurança e à compatibilidade das operações entre os países. Representantes de 52 nações, incluindo o Brasil, reuniram-se em dezembro de 1944 na Conferência Internacional de Aviação Civil em Chicago para elaborar a Convenção de Aviação Civil Internacional (CACI), conhecida também como Convenção de Chicago. A CACI criou a Organização de Aviação Civil Internacional (OACI), agência especializada das Nações Unidas responsável pela promoção do desenvolvimento seguro e ordenado da aviação civil mundial por meio do estabelecimento de normas e regulamentos necessários para a segurança, eficiência e regularidade das operações, bem como para a proteção ambiental da aviação (ANAC, 2016).

Atualmente a OACI trabalha com 191 Estados Contratantes da Convenção de Chicago e grupos da indústria para o estabelecimento consensual das SARPs (Standards and Recommended Practices), conjunto de padrões, recomendações e práticas recomendadas que regem o setor da Aviação Civil Internacional (OACI, 2016).

A CACI, da qual o Brasil é signatário, estabelece que:

\section{ARTIGO 37}

Adoção de normas e processos internacionais

Os Estados Contratantes se comprometem a colaborar a fim de lograr a maior uniformidade possível em regulamentos, padrões, normas e organização relacionadas com as aeronaves, pessoal, aerovias e serviços auxiliares, em todos os casos em que a uniformidade facilite e melhore a navegação aérea.

Para este fim, a Organização Internacional de Aviação Civil adotará e emendará, oportunamente, segundo a necessidade, as normas internacionais e as práticas e processos relativos aos pontos seguintes: 
(a) Sistema de comunicação e auxílio à navegação aérea, inclusive as marcações terrestres;

(b) Características de aeroportos e áreas de pouso;

(c) Regras de tráfego e métodos de controle de tráfego aéreo;

(d) Licenças para o pessoal de voo e mecânicos;

(e) Navegabilidade das aeronaves;

(f) Registro e matrícula de aeronaves;

(g) Coleta e troca de dados meteorológicos;

(h) Livros de bordo;

(i) Mapas e cartas;

(j) Formalidades de alfândega e de imigração; e

(k) Aeronaves em perigo e investigação de acidentes.

Assim como todas as sugestões relacionadas com a segurança, regularidade e eficiência de navegação aérea que oportunamente forem necessárias (Brasil, 1946).

Para o cumprimento do Artigo 37 da CACI, a OACI publicou e tornou efetivo 19 Anexos à Convenção de Chicago, estabelecendo as SARPS das quais os Estados Contratantes se comprometem a seguir para diversas áreas da Aviação Civil Internacional.

\subsection{Evolução das Normas Técnicas e da Infraestrutura Aeroportuária Brasileira}

O regulamento da OACI que versa sobre as normas técnicas de Aeroportos e Aeródromos é o Anexo 14 à CACI, cuja primeira edição se tornou efetiva em 01 de novembro de 1951.

Desde a primeira edição desse regulamento, um dos desafios enfrentados pela OACI no que tange a implementação das SARPs foi a dificuldade de adequação dos aeroportos que já estavam construídos às normas internacionais. Assim, o Anexo 14, $1^{\text {a }}$ edição, possuía basicamente recomendações aos Estados Contratantes (OACI, 1951).

O primeiro aeroporto construído no Brasil que continua em operação é o Aeroporto de Campo de Marte, inaugurado em 1920. Todavia, esse aeroporto não é utilizado para aviação regular, ficando restrito às operações de aeronaves de menor porte. A partir de então, vários aeroportos foram construídos no Brasil durante o desenvolvimento inicial da aviação civil, quando não existia nenhuma norma técnica de Projeto de Aeroportos.

Os terminais aeroportuários brasileiros mais antigos que continuam com operações regulares são apresentados na Tabela 1. 
Tabela 1 - Aeroportos mais antigos do Brasil com operação regular

\begin{tabular}{cc}
\hline Aeroporto & Ano de Inauguração \\
\hline Aeroporto de Salvador & 1925 \\
Aeroporto de Florianópolis & 1927 \\
Aeroporto de Fortaleza & 1930 \\
Aeroporto de Belo Horizonte (Pampulha) & 1933 \\
Aeroporto de Congonhas & 1936 \\
Aeroporto Santos Dumont & 1936 \\
Aeroporto de Porto Alegre & 1940 \\
Aeroporto de Vitória & 1946 \\
Aeroporto de Curitiba & 1946 \\
\hline
\end{tabular}

Fonte: Infraero, $\overline{2016}$

Com a evolução da Aviação Civil, em especial da Indústria Aeronáutica, houve um grande desenvolvimento tecnológico no setor, o que fez com que a OACI constantemente atualizasse as SARPs referentes aos requisitos técnicos de aeródromos, como pode ser visto na Tabela 2.

Tabela 2 - Histórico de emendas do Anexo 14 à Convenção de Chicago

\begin{tabular}{|c|c|}
\hline Documento & Data de Efetivação \\
\hline Anexo $14,1^{a}$ edição & $01 / 11 / 1951$ \\
\hline Anexo $14,2^{\mathrm{a}}$ edição & $01 / 09 / 1953$ \\
\hline Anexo $14,3^{a}$ edição & $01 / 12 / 1958$ \\
\hline Anexo $14,4^{\mathrm{a}}$ edição & 01/11/1964 \\
\hline Anexo $14,5^{a}$ edição & 18/09/1969 \\
\hline Anexo $14,6^{a}$ edição & 06/01/1972 \\
\hline Anexo $14,7^{a}$ edição & $30 / 12 / 1976$ \\
\hline Anexo $14,8^{a}$ edição & 24/11/1983 \\
\hline Anexo 14, Volume I (Aeródromos) $1^{\mathrm{a}}$ edição & $15 / 11 / 1990$ \\
\hline Anexo 14, Volume I (Aeródromos) $2^{\mathrm{a}}$ edição & 09/11/1995 \\
\hline Anexo 14, Volume I (Aeródromos) $3^{\mathrm{a}}$ edição & 04/11/1999 \\
\hline Anexo 14, Volume I (Aeródromos) $4^{\text {a edição }}$ & $25 / 11 / 2004$ \\
\hline Anexo 14, Volume I (Aeródromos) $5^{\mathrm{a}}$ edição & $19 / 11 / 2009$ \\
\hline Anexo 14, Volume I (Aeródromos) $6^{\mathrm{a}}$ edição & $14 / 11 / 2013$ \\
\hline
\end{tabular}


As primeiras edições do Anexo 14 classificavam as Pistas de Pouso e Decolagem de acordo com os seus comprimentos (dimensão longitudinal) e esta classificação determinava os requisitos técnicos que os aeroportos deveriam seguir.

A partir da $8^{\text {a }}$ edição do Anexo 14, a OACI implementou a classificação atual das Pistas de Pouso e Decolagem denominada Código de Referência de Aeródromo que é baseada na aeronave crítica (aeronave mais exigente em termos geométricos ou de performance de pouso e decolagem). Dessa forma, com base na aeronave crítica que um aeroporto deseja operar são estabelecidos os requisitos para os quais sua infraestrutura deve estar dimensionada (OACI, 1983).

Outra alteração significativa do Anexo 14 foi a recomendação das instalações das Áreas de Segurança de Fim de Pista (RESA - Runway End Safety Areas) a partir da sua $7^{\text {a }}$ edição, o que mostra a preocupação da OACI com a segurança das operações de pouso e decolagem devido ao crescimento das ocorrências de excursões de fim de pista (OACI, 1976).

Com a publicação do Anexo 14, Volume I (Aeródromos), $3^{\text {a }}$ edição, a OACI transformou essa recomendação em padrão (standard) para os aeroportos em que operavam as aeronaves de médio e de grande porte, ou seja, quaisquer aeródromos da letra do código de referência 3 ou 4 ou aeródromos de aproximação por instrumento da letra do código de referência 1 ou 2 (OACI, 1999).

Assim, devido à evolução das normas técnicas do setor de infraestrutura aeroportuária e ao fato de grande parte dos investimentos neste setor se constituírem de custos afundados (sunk cost), houve um descompasso entre a infraestrutura instalada nos aeroportos e os requisitos técnicos preconizados pela $\mathrm{OACI}$, dos quais o Estado Brasileiro comprometeu-se a seguir como signatário da Convenção de Chicago.

Cabe ressaltar que a CACI estabelece que:

ARTIGO 38 (Diferenças entre as normas e processos internacionais)

Se um Estado se vê impossibilitado de cumprir em todos os seus detalhes certas normas ou processos internacionais, ou de fazer que seus próprios regulamentos e práticas concordem por completo com as normas e processos internacionais que tenham sido objeto de emendas, ou se o Estado considerar necessário adotar regulamentos e práticas diferentes em algum ponto dos estabelecidos por normas internacionais, informará imediatamente a Organização Internacional de Aviação Civil das diferenças existentes entre suas próprias práticas e as internacionais. Em caso de emendas a estas últimas, o Estado que não fizer estas alterações nos seus regulamentos ou práticas deverá informar o Conselho dentro do período de 60 dias a contar da data em que for adotada a emenda às normas internacionais, ou indicará o que fará a 
esse respeito. Em tal caso o Conselho notificará imediatamente a todos os demais Estados a diferença existente entre as normas internacionais e as normas correspondentes no Estado em apreço (Brasil, 1946).

Desta forma, apesar dos Estados Contratantes se comprometerem pelo Artigo 37 da CACI a lograr a maior uniformidade possível aos regulamentos, padrões e normas estabelecidos pela Organização de Aviação Civil Internacional, os Estados possuem autonomia para divergir dos requisitos internacionais e estabelecer as suas próprias regulações, desde que notifiquem a OACI e consequentemente a comunidade internacional das diferentes práticas adotadas dentro do Estado.

Através da Portaria n 398/GM5, de 4 de junho de 1999, que dispõe sobre a aplicação do Anexo 14 à Convenção de Aviação Civil Internacional no Território Nacional, o Brasil aprovou a utilização integral do Anexo 14 em território nacional (Brasil, 1999).

\subsection{Objetivos das normas técnicas}

A regulação técnica da Aviação Civil, em especial das Infraestruturas Aeroportuárias, é uma Regulação de Comando e Controle fortemente baseada em compliance às normas técnicas internacionais.

Um dos objetivos desta grande padronização da Aviação Civil Internacional é a garantia da interoperabilidade das operações, visto que um voo internacional decola e pousa em países distintos, e caso as infraestruturas dos aeroportos não fossem semelhantes, o risco de acidentes devido à fatores humanos seria aumentado. Assim, é requerida a padronização da Infraestrutura Aeroportuária, principalmente dos Auxílios Visuais à Navegação, que são um conjunto de sinalizações horizontais, luminosas e verticais que devem ser instaladas nos Aeroportos para auxiliar os pilotos durante as operações de pouso, movimentação em solo e decolagem.

Todavia, nem todos os requisitos técnicos estabelecidos pelo Anexo 14 são motivados para a compatibilidade entre os aeroportos e a garantia da interoperabilidade. Muitos desses, principalmente os denominados "Características Físicas", são requisitos geométricos para o projeto (layout) do aeroporto que se constituem em defesas para o caso em que alguma aeronave eventualmente saia da pista de pouso e decolagem, mitigando então os riscos inerentes às operações das aeronaves nos aeródromos. 


\subsection{Modelo Regulatório atual}

Em 2009, após a criação da Agência Nacional de Aviação Civil, foi publicado o Regulamento Brasileiro de Aviação Civil RBAC 154 - Projeto de Aeródromos, que internaliza os requisitos de projeto de aeródromos do Anexo 14 no Brasil (ANAC, 2009).

O RBAC 154 é quase em sua totalidade baseado no Anexo 14, com pequenas diferenças pontuais em alguns requisitos técnicos. Porém, uma diferença significativa trazida pelo RBAC 154 é o fato de que todas as recomendações contidas no Anexo 14 foram internalizadas no Brasil como padrão (standard), o que enrijeceu o regulamento brasileiro. No entanto, o RBAC 154 estabelece que:

\section{5 - Normas}

(d) (...) Em geral, a menos que a ANAC julgue necessário e defina um prazo específico, as instalações aeroportuárias existentes não precisam ser imediatamente modificadas em acordo com as novas exigências, até que a instalação seja substituída ou melhorada para acomodar aeronaves que possuem maiores exigências (ANAC, 2009).

Assim, para os novos aeroportos construídos e abertos ao tráfego aéreo após a publicação do RBAC 154 em 2009 é exigida a adequação total da infraestrutura aeroportuária a todas as normas e práticas recomendadas do Anexo 14 da OACI. O mesmo se aplica aos aeroportos já construídos e abertos ao tráfego aéreo até 2009 e que depois desta data venham requerer operações de aeronaves que demandem uma maior infraestrutura.

Todavia, não ficou claro se a ANAC demandaria a adequação dos aeroportos já construídos e abertos ao tráfego aéreo até 2009 que não viessem a ser expandidos para acomodação de operações de aeronaves mais exigentes.

A ANAC (2014) publicou, então, a Decisão n 134, de 17 de setembro de 2014, que fixa a interpretação a respeito da aplicabilidade de dispositivos do RBAC 154, dispondo que:

Art. $1^{\circ}$ Fixar a interpretação do parágrafo 154.5 (d) do Regulamento Brasileiro da Aviação Civil no 154, para esclarecer que os requisitos previstos no regulamento aplicam-se aos seguintes casos:

I - instalações aeroportuárias não existentes em 12 de maio de 2009; e

II - instalações aeroportuárias existentes em 12 de maio de 2009:

\section{(...)}

b) que forem substituídas ou melhoradas após esta data para acomodar aeronaves que possuam maiores exigências;

c) quando for determinado pela ANAC em processos de certificação operacional de aeroportos ou em programas específicos de adequação de infraestruturas às regras do $\operatorname{RBAC~} n^{\circ} 154$; ou 
d) em hipóteses comprovadamente excepcionais, quando a ANAC, diante do elevado risco operacional identificado, julgar necessário e definir um prazo específico.

(...)

Art. $2^{\circ}$ Exceções à aplicação do $\mathrm{RBAC} \mathrm{n}^{\circ} 154$ podem ser admitidas:

(...)

II - no processo de certificação operacional de aeroporto, quando a adoção de Procedimentos Especiais for autorizada pela ANAC, por meio da Superintendência de Infraestrutura Aeroportuária, em conjunto com o Departamento de Controle do Espaço Aéreo - DECEA, quando couber, desde que seja garantido nível de segurança operacional equivalente ao que seria assegurado pelas normas vigentes, observado o disposto na seção 139.501 do RBAC nº 139 (ANAC, 2014).

Dessa forma, a ANAC estabeleceu que, mesmo para as infraestruturas aeroportuárias existentes antes da publicação do RBAC 154 que não forem substituídas ou melhoradas para acomodar aeronaves que possuam maiores exigências, ainda assim é necessária a adequação das infraestruturas às normas contidas no RBAC 154, com exceção na hipótese do Operador do Aeródromo comprovar que mantém um nível equivalente de segurança operacional com a adoção de Procedimentos Especiais no processo de Certificação Operacional de Aeroportos.

O Processo de Certificação Operacional é uma exigência da OACI aos Estados contratantes, de acordo com o Anexo 14, que dispõe que:

Os Estados devem certificar os aeródromos utilizados para as operações internacionais em conformidade com as especificações contidas neste Anexo, bem como em outras especificações relevantes da OACI através de um modelo regulatório apropriado. A intenção dessas especificações é assegurar o estabelecimento de um regime regulatório em que a conformidade com as especificações contidas neste Anexo possa ser efetivamente garantida (OACI, 2013, Tradução própria).

No Brasil, o processo de Certificação Operacional de Aeroportos é regido pelo Regulamento Brasileiro de Aviação Civil - RBAC 139. Este processo, diferentemente do previsto pela OACI, era obrigatório apenas aos aeroportos que operavam mais de 1 milhão de passageiros, e não exclusivamente aos aeroportos de operações internacionais.

A ANAC estabeleceu, através do RBAC 139, Emenda 05, de 15 de dezembro de 2015, que estabelece:

139.1 Aplicabilidade

(a) Este Regulamento é de cumprimento obrigatório pelo operador de aeródromo que atua em aeródromo civil público brasileiro, compartilhado ou não, que processa ou pretende processar:

(1) operações domésticas ou de bandeira, regidas pelo RBAC 121; 
(2) operações suplementares, regidas pelo RBAC 121, quando houver regularidade; ou

(3) operações de empresas estrangeiras que têm por objetivo o transporte aéreo civil público no Brasil, regidas pelo RBAC 129.

139.601 Disposições transitórias e finais

(a) Operadores de aeródromos classificados, na data de emissão da Emenda 05 deste Regulamento, como Classe I, II ou III segundo o RBAC 153, Emenda 00, ficam dispensados de serem detentores de Certificado Operacional de Aeroporto, até que requeiram:

(1) aumento de frequências da aeronave crítica; ou

(2) operações mais exigentes (ANAC, 2015).

Assim, a ANAC recentemente ampliou a obrigatoriedade da obtenção do Certificado Operacional de Aeroportos a todos os Operadores de Aeródromos que operam aeroportos com voos regulares (operações domésticas ou de bandeira, operações suplementares com regularidade, ou operações internacionais com objetivo o transporte aéreo público no Brasil), dispensando apenas os aeroportos que operam menos do que 1 milhão de passageiros, desde que não aumentem a frequência de operações da aeronave crítica ou não solicitem a operação de aeronaves mais exigentes.

Deste modo, qualquer aeroporto que opere voos regulares, para permitir o seu desenvolvimento (aumento de frequências da aeronave crítica ou aumento do porte das aeronaves) deverá obter a sua certificação de acordo com o RBAC 139, comprovando então a conformidade aos requisitos de Projeto de Aeródromos contidos no RBAC 154 ou o Operador de Aeródromo demonstrando que mantém um nível de segurança operacional equivalente àquele que seria obtido pela conformidade aos requisitos técnicos vigentes.

\subsection{Análise de Risco em Aeroportos}

A Análise de Risco nos Aeroportos é, portanto, uma ferramenta que os Operadores de Aeródromos utilizam para avaliar os riscos das operações e demonstrar para a Agência que mantêm um nível aceitável de segurança operacional.

A OACI (2015) estabeleceu no DOC 9981, intitulado Procedures for Air Navigation Services - Aerodromes (PANS-Aerodromes), uma metodologia para a Análise de Risco nos Aeroportos (Safety Assessments for Aerodromes).

Diversas ferramentas estatísticas foram desenvolvidas pela indústria e academia para se avaliar os riscos em termos de probabilidade de ocorrência dos eventos catastróficos em aeroportos como a ocorrência de excursões de fim de pista (overrun), excursões laterais (veer- 
off) e pousos antes da pista de pouso e decolagem (undershoot), que são os tipos de acidentes que podem acontecer durante a operação de pouso e decolagem das aeronaves motivados pela deficiência da infraestrutura às normas técnicas "Características Físicas" constantes dos requisitos de Projeto de Aeródromo. Dentre as ferramentas desenvolvidas, destacam-se os trabalhos desenvolvidos pelo ACRP (Airport Cooperative Research Program) do National Academies of Sciences, Engineering, and Medicine.

\subsection{Problema}

O modelo regulatório estabelecido pela ANAC, que exige a adequação dos aeroportos já construídos aos requisitos de projeto de aeródromos ou a comprovação de que o aeroporto mantém um nível de segurança operacional segundo parâmetros internacionais, é a solução ótima do ponto de vista de bem-estar social para o Estado Brasileiro? Ou outras variáveis deveriam ser consideradas sistemicamente para uma tomada de decisão da Agência quanto a adequação destes aeroportos?

\subsection{Metodologia}

Para responder à questão proposta, realizou-se uma revisão bibliográfica de Análise de Impacto Regulatório e Valor da Vida Humana. Os resultados da revisão bibliográfica foram aplicados então ao Estudo de Caso da análise de custo-benefício da adequação do Aeroporto de Congonhas aos requisitos regulamentares. 


\section{ANÁLISE DE IMPACTO REGULATÓRIO}

Políticas que reduzem riscos de mortalidade deveriam ser submetidas a requisitos econômicos para se assegurar a sua eficácia da mesma forma que qualquer outro gasto público (VISCUSI, 1994).

Todavia, o modelo regulatório de avaliação da segurança das infraestruturas aeroportuárias, conforme apresentado no Capítulo 1, não possui nenhum mecanismo para avaliar economicamente a adequação das infraestruturas aeroportuárias existentes aos requisitos técnicos. Assim, é necessária uma discussão maior sobre as consequências dessa regulação e sua efetividade.

A discussão da qualidade e eficácia regulatória já é antiga. De acordo com Hahn e Litan (2003), quem cunhou o termo Análise de Impacto Regulatório - AIR foi Ronald Reagan em 1981.

Desde a criação da AIR, esta ferramenta tem um papel fundamental na proposição de novas regulações e na avaliação de regulações existentes em diversos países, sendo que quase todos os países membros da OCDE (Organização para a Cooperação e Desenvolvimento Econômico) já a utilizam amplamente na avaliação de seus processos regulatórios. Muito dos países que a utilizam estão empreendendo esforços no processo de revisão de suas metodologias de AIR, visto que ainda há espaço para melhoria (OCDE, 2009a).

Segundo Gaetani e Albuquerque (2009):

A análise de impacto regulatório é instrumento formal que permite a explicitação dos problemas regulatórios, das opções disponíveis de política e das consequências das decisões regulatórias, em cada caso concreto, mediante a utilização de dados empíricos. Trata-se, portanto, de ferramenta que tem o condão de conferir estrutura, consistência, rigor e transparência à revisão regulatória e vem sendo amplamente utilizada no contexto internacional em programas de melhoria regulatória.

Ramos (2009) afirmou que "mais do que um método, a AIR é um processo para a tomada de decisões regulatórias, baseado em exame sistêmico e consistente de impactos potenciais derivados da regulação governamental”.

\subsection{Metodologias de AIR}

Diversas metodologias analíticas para se avaliar os impactos de uma regulação foram desenvolvidas na literatura e são utilizadas em vários casos reais, tanto para análise de um novo 
marco regulatório (ex ante), como para a avaliação da eficácia de regulações já implementadas (ex post). Neste trabalho serão destacadas quatro metodologias:

- Análise de Custo-Benefício - ACB;

- Análise de Custo-Efetividade - ACE;

- Análise Multicritério à Decisão - AMD (ou apenas Análise Multicritério);

- Análise de Risco - AR.

\subsubsection{Análise de Custo-Benefício}

A Análise de Custo-Benefício (ACB) pode ser considerada tanto como uma abordagem para orientar a tomada de decisão dos agentes públicos, como também uma metodologia específica para a condução de uma AIR. A rigor, é possível considerar que todas as metodologias de AIR seguem os princípios gerais da ACB, ou seja, o objetivo geral da condução de uma AIR é tentar garantir que as regulações são apenas propostas (ou mantidas) quando os seus benefícios são superiores aos custos incorridos pela sociedade (OCDE, 2008).

Adicionalmente, a OCDE (2008) ainda indica que existe um risco real que se a AIR não for utilizada, os custos sociais impostos pela regulação serão consideravelmente superiores aos benefícios. Isto pois, os grupos, ou a parcela da população, que auferirão os benefícios e não incorrerão em custos (ou que lograrão mais benefícios do que custos) irão frequentemente realizar um intenso lobby para a regulação ser estabelecida. Do outro lado, os grupos que suportarão os custos eventualmente não possuem uma real ciência de sua extensão, e muitas vezes não são organizados suficientemente para realizar um lobby contra a proposição da regulação.

Para a utilização da $\mathrm{ACB}$, os principais (maiores e mais prováveis) benefícios e custos devem ser identificados e estimados. Caso não seja possível a estimação de todos os benefícios e custos, uma Análise de Custo-Benefício Parcial pode ser realizada e ainda ser de grande valia para o processo de tomada de decisão, visto que reduz a extensão das análises qualitativas e, portanto, mais subjetivas, que venham a ser necessárias para a conclusão da análise.

A mensuração dos benefícios normalmente é mais complexa do que a estimativa dos custos, visto que estes são normalmente calculados através de um processo em duas etapas: a elaboração de uma Análise de Risco e o valuation dos benefícios. Ambas as tarefas são difíceis, mas possivelmente a mais complexa é a valoração dos benefícios quando estes são "não- 
comercializáveis" (non-market items), como o valor da vida humana e o valor de se salvar espécies de animais em extinção (Broder e Morrall III, 1997).

Durante muito tempo houve grande relutância na condução de Análises de CustoBenefício para a Regulação de Segurança, de Saúde Pública e de Meio-Ambiente devido ao fato da dificuldade de se mensurar os bens não-comercializáveis, em especial o Valor da Vida Humana. Todavia, após o desenvolvimento deste tema, com o estabelecimento de conceitos mais adequados e métodos científicos para o cálculo desses valores, a ACB ganhou um importante papel no processo legislativo e regulatório de questões afetas a esses temas, permitindo a ilustração dos tradeoffs que são inerentes à elaboração de Políticas Públicas e levando à elaboração de leis e regulações mais transparentes e alinhadas com as prioridades estabelecidas pela sociedade (ARROW et. al., 1996).

O Capítulo 3 apresenta uma revisão bibliográfica sobre o Valor da Vida Humana bem como o cálculo deste valor para o passageiro do transporte regular da Aviação Civil Brasileira.

\subsubsection{Analise de Custo-Efetividade}

Segundo a OCDE (2008), quando não é factível a utilização da ACB, a Análise de Custo-Efetividade (ACE) é normalmente utilizada como base para a AIR. Enquanto a ACB identifica e quantifica os custos e benefícios de uma regulação, a ACE avalia múltiplas soluções em que se espera alcançar o benefício esperado, se resumindo então à quantificação dos custos e à escolha da solução ótima que incorre no menor custo para alcançar o objetivo estabelecido.

Assim a utilização do ACE é mais simples, demandando menos expertise e recursos para a sua condução. Todavia, a utilização da Análise de Custo-Efetividade não garante que a regulação deve ser estabelecida do ponto de vista de bem-estar social, respondendo apenas à questão de que se a regulação necessita ser implementada, qual seria a melhor alternativa para a sociedade (OCDE, 2008).

\subsubsection{Análise Multicritério}

A Análise Multicritério (AMD) constitui um processo de identificação dos objetivos de uma política e estabelecimento de critérios e pesos para se mensurar a sua importância. Através destes critérios e pesos, várias opções de regulação podem ser avaliadas e ranqueadas visando ao estabelecimento da regulação ótima para se alcançar os objetivos pretendidos pela política (OCDE, 2008). 
Desta forma, a AMD normalmente consiste em uma alternativa à condução de ACB ou ACE, visto a sua simplicidade e transparência. Quando não é possível estimar uma parcela significativa dos custos, ou quando não se consegue monetizar benefícios importantes da política, a elaboração de uma Análise Multicritério é recomendada. Todavia, a utilização apenas da AMD, além de também não garantir que a regulação deve ser implantada, não mensura objetivamente os custos, podendo levar à escolha de soluções muito onerosas para a sociedade.

Nem sempre a utilização da AMD é uma alternativa à elaboração de uma Análise de Custo-Benefício. Alguns objetivos de uma política não são capturados por uma $\mathrm{ACB}$, como por exemplo, efeitos de distribuição de renda entre a população, que são anulados pela soma dos benefícios e custos. Nestes casos, pode ser fundamental a condução de uma Análise Multicritério, levando a ACB a um objetivo secundário no processo de escolha entre as alternativas (OCDE, 2009).

\subsubsection{Análise de Risco}

Um elemento chave da análise de qualquer regulação que proponha reduzir riscos à saúde, à segurança e ao meio ambiente é a estimativa do risco alvo da política e de suas consequências. Assim, a metodologia de Análise de Risco (AR) avalia apenas um dos aspectos dos benefícios objetivados pela política que é a redução da magnitude do risco, sem a sua monetarização como ocorre na ACB e sem a quantificação dos custos necessária para a ACB e a ACE (VISCUSI, 1997).

Para a utilização da Análise de Risco como metodologia para AIR é necessário o estabelecimento de limites bem definidos (Acceptable Risk Threshold) entre riscos aceitáveis e riscos não-aceitáveis. Caso não seja estabelecido o limite de risco ou não se tenha claramente definido como os vários níveis de risco serão julgados, o resultado inevitável é um julgamento subjetivo ou inconsistente das regulações (OCDE, 2009b).

Todavia, mesmo com o estabelecimento dos critérios de aceitabilidade bem definidos, os resultados do AIR pela Análise de Risco e pela Análise de Custo-Benefício podem ser contraditórios, dado que a ACB adota uma visão puramente utilitarista do risco, requerendo que a redução do risco seja sempre buscada quando os benefícios esperados superam os custos, independentemente se o risco inicial (ex ante) era avaliado como inaceitável ou aceitável. Ainda pode ocorrer a contradição de se determinar a redução do risco mesmo sabendo que serão incorridos pela sociedade custos superiores aos benefícios estimados pela implementação da regulação (OCDE, 2009b). 


\subsection{Utilização de AIR na Aviação Civil}

Ao se avaliar as metodologias de AIR previstas na literatura, pode-se entender que o Modelo Regulatório da ANAC para os requisitos de Projeto de Aeroportos, que isenta a adequação dos aeroportos já construídos anteriormente à data de publicação do RBAC 154 que comprovarem possuir um nível aceitável de segurança operacional, é baseado na realização de uma AIR através da utilização da metodologia de Análise de Risco.

A OACI já estabeleceu várias orientações para os Estados Contratantes sobre o Processo de Análise e Gerenciamento de Risco, dentre os quais se destacam o Anexo 19, Safety Management (OACI, 2013a); o DOC 9859, Safety Management Manual (OACI, 2013b); e o DOC 9981, PANS-Aerodromes (OACI, 2015). Esses documentos estabelecem uma metodologia para a identificação de perigos e critérios para avaliar o risco de um determinado perigo na Aviação Civil.

O risco é definido pela OACI como uma variável bidimensional composta por Probabilidade e Severidade. A probabilidade é definida pela taxa esperada de recorrência do evento, enquanto a severidade é estimada pela consequência mais crível do evento (most credible outcome) e não com pior consequência possível (worst case scenario).

A Probabilidade e a Severidade de um evento são classificadas de acordo com as Tabela 3 e Tabela 4.

Tabela 3 - Probabilidade do evento

\begin{tabular}{clc}
\hline Classificação & Significado & Valor \\
\hline Frequente & Provável que ocorra muitas vezes (ocorre frequentemente) & 5 \\
\hline Ocasional & Provável que ocorra algumas vezes (ocorre com pouca frequência) & 4 \\
\hline Remoto & Improvável que ocorra, mas possível (ocorre raramente) & 3 \\
\hline Improvável & Bastante improvável que ocorra & 2 \\
\hline Muito improvável & Quase inconcebível que o evento ocorra & 1 \\
\hline Fonte: OACI, 2015 (Tradução própria).
\end{tabular}


Tabela 4 - Severidade do evento

\begin{tabular}{|c|c|c|}
\hline Classificação & Significado & Valor \\
\hline Catastrófico & $\begin{array}{l}\text { - Destruição de equipamento } \\
\text { - Múltiplas mortes }\end{array}$ & $\mathrm{A}$ \\
\hline Crítico & $\begin{array}{l}\text { - Uma redução importante das margens de segurança operacional, } \\
\text { dano físico ou uma carga de trabalho tal que os operadores não } \\
\text { podem desempenhar suas tarefas de forma precisa e completa } \\
\text { - Lesões sérias } \\
\text { - Grave dano ao equipamento }\end{array}$ & $\mathrm{B}$ \\
\hline Significativo & $\begin{array}{l}\text { - Uma redução significativa das margens de segurança operacional, } \\
\text { uma redução na habilidade do operador em responder a condições } \\
\text { operacionais adversas como resultado do aumento da carga de } \\
\text { trabalho ou como resultado de condições que impedem sua } \\
\text { eficiência } \\
\text { - Incidente sério } \\
\text { - Lesões às pessoas }\end{array}$ & $\mathrm{C}$ \\
\hline Pequeno & $\begin{array}{l}\text { - Interferência } \\
\text { - Limitações operacionais } \\
\text { - Utilização de procedimentos de emergência } \\
\text { - Incidentes menores }\end{array}$ & $\mathrm{D}$ \\
\hline Insignificante & - Consequências leves & $\mathrm{E}$ \\
\hline
\end{tabular}

Fonte: OACI, 2015 (Tradução própria).

Uma vez definida a Probabilidade e Severidade do risco, o risco é classificado como Aceitável, Aceitável com Mitigação ou Inaceitável através da Matriz de Riscos, contida no Quadro 1, e da Classificação dos Riscos, contida na Quadro 2.

Quadro 1 - Matriz de Riscos

\begin{tabular}{|c|c|c|c|c|c|c|}
\hline \multirow{2}{*}{\multicolumn{2}{|c|}{$\begin{array}{c}\text { Probabilidade do } \\
\text { risco }\end{array}$}} & \multicolumn{5}{|c|}{ Severidade do risco } \\
\hline & & $\begin{array}{c}\text { Catastrófico } \\
\text { A }\end{array}$ & $\begin{array}{c}\text { Crítico } \\
\text { B }\end{array}$ & $\begin{array}{c}\text { Significativo } \\
\mathrm{C}\end{array}$ & $\begin{array}{c}\text { Pequeno } \\
\text { D }\end{array}$ & $\begin{array}{c}\text { Insignificante } \\
\text { E }\end{array}$ \\
\hline Frequente & 5 & $5 \mathrm{~A}$ & $5 \mathrm{~B}$ & $5 \mathrm{C}$ & $5 \mathrm{D}$ & $5 \mathrm{E}$ \\
\hline Ocasional & 4 & $4 \mathrm{~A}$ & $4 \mathrm{~B}$ & $4 \mathrm{C}$ & $4 \mathrm{D}$ & $4 \mathrm{E}$ \\
\hline Remoto & 3 & $3 \mathrm{~A}$ & $3 \mathrm{~B}$ & $3 \mathrm{C}$ & $3 \mathrm{D}$ & $3 \mathrm{E}$ \\
\hline Improvável & 2 & $2 \mathrm{~A}$ & $2 \mathrm{~B}$ & $2 \mathrm{C}$ & $2 \mathrm{D}$ & $2 \mathrm{E}$ \\
\hline $\begin{array}{c}\text { Muito } \\
\text { Improvável }\end{array}$ & 1 & $1 \mathrm{~A}$ & $1 \mathrm{~B}$ & $1 \mathrm{C}$ & $1 \mathrm{D}$ & $1 \mathrm{E}$ \\
\hline
\end{tabular}

Fonte: OACI, 2015 (Tradução própria). 
Quadro 2 - Classificação dos Riscos

\begin{tabular}{|c|c|c|}
\hline Gerenciamento do risco & $\begin{array}{c}\text { Índice de avaliação } \\
\text { do risco }\end{array}$ & Critério sugerido \\
\hline Região intolerável & $\begin{array}{l}5 \mathrm{~A}, 5 \mathrm{~B}, 5 \mathrm{C} \\
4 \mathrm{~A}, 4 \mathrm{~B}, 3 \mathrm{~A}\end{array}$ & Inaceitável sob as circunstâncias existentes \\
\hline \multirow{2}{*}{$\begin{array}{l}\text { Região tolerável } \\
\text { Região aceitável }\end{array}$} & $\begin{array}{l}5 \mathrm{D}, 5 \mathrm{E}, 4 \mathrm{C}, 4 \mathrm{D} \\
4 \mathrm{E}, 3 \mathrm{~B}, 3 \mathrm{C}, 3 \mathrm{D} \\
2 \mathrm{~A}, 2 \mathrm{~B}, 2 \mathrm{C}, 1 \mathrm{~A}\end{array}$ & Aceitável com mitigação do risco \\
\hline & $\begin{array}{c}3 \mathrm{E}, 2 \mathrm{D}, 2 \mathrm{E} \\
1 \mathrm{~B}, 1 \mathrm{C}, 1 \mathrm{D}, 1 \mathrm{E}\end{array}$ & Aceitável \\
\hline
\end{tabular}

Fonte: OACI, 2015 (Tradução própria).

Assim, a OACI prevê um processo sistemático para a identificação, avaliação e gerenciamento dos riscos da Aviação Civil, o que reduz de forma significativa a subjetividade deste processo. Todavia, não existe o estabelecimento de limites bem definidos entre riscos (probabilidades) aceitáveis e inaceitáveis para cada severidade. Por exemplo, ao se avaliar o perigo de uma aeronave sair da Pista de Pouso e Decolagem através de uma excursão de fim de pista (overrrun), a consequência mais crível determinada pela Tabela 4 é classificada como Catastrófica, já que seria esperada a destruição de equipamento ou múltiplas mortes (ou até mesmo ambos). Para essa Severidade, não existe o estabelecimento de um limite bem definido para riscos (probabilidades) aceitáveis e inaceitáveis (Acceptable Risk Threshold).

No Brasil, a IAC 154-1001, que estabelece o Termo de Referência de Estudo Aeronáutico, sugere alguns limites de risco normalmente utilizados internacionalmente para infraestrutura aeroportuária como sendo aceitáveis $\left(1,0 \times 10^{-7}\right)$, porém esse nível não é estabelecido como requisito regulatório, sendo apenas sugestão para ser utilizado pelos Operadores de Aeródromos (DAC, 2004).

\subsubsection{AIR na Organização de Aviação Civil Internacional}

A ausência de uma Análise de Impacto Regulatório mais objetiva na Aviação Civil com a avaliação de custos e benefícios das novas normas e recomendações (SARPs) por parte da OACI é discutida em vários países e até mesmo na própria Organização de Aviação Civil Internacional.

Na $37^{\mathrm{a}}$ Assembleia da OACI, o Estado Neozelandês apresentou o paper (A37-WP/114) intitulado "Making New Standards And Recommended Practices: Impact Assessment", no qual o representante deste país afirmou que o processo de desenvolvimento de novas SARPs não identifica e estima sistematicamente o impacto para os Estados e para a Indústria das novas 
regras estabelecidas pela OACI. Assim, os custos da identificação dos impactos são transferidos da OACI, fórum no qual as políticas são decididas, para os Estados, muitos dos quais possuem envolvimento limitado na elaboração das normas internacionais (Nova Zelândia, 2010).

No mesmo documento, a Nova Zelândia expõe que para se preservar a autoridade das SARPs da OACI no Sistema de Aviação Civil, o processo de elaboração dos novos requisitos deve possuir uma argumentação sólida, com maiores explicações e justificativa das suas escolhas regulatórias, da mesma forma que acontece na elaboração de Projetos de Lei nos Poderes Legislativos de vários Estados Contratantes.

Apesar desta discussão muito pertinente, tendo a OACI determinado na HLSC 2010 (High-level Safety Conference) que a organização deve estabelecer uma metodologia para AIR a ser usada nos seus futuros requisitos técnicos, isto não exime os países de realizarem as suas próprias AIR para adoção das novas normas propostas pela OACI, e até mesmo das normas existentes, dada a Soberania dos Estados em declarar diferenças às normas internacionais, de acordo com a previsão disposta pelo Artigo 38 da CACI.

\subsection{Metodologia Proposta}

O propósito primordial de obter uma avaliação dos méritos de políticas regulatórias é assegurar que estas tenham uma sólida base econômica e social. Desta forma, é possível responder à seguinte pergunta: A sociedade está obtendo benefícios suficientes derivados de tais políticas para justificar os custos que estão sendo impostos? Uma vez que estes custos não são incorridos pelos entes públicos e sim suportados por terceiros, os tomadores de decisão muitas vezes os menosprezam, diferentemente do que fariam se estivessem lidando com despesas públicas. Adicionalmente, é importante realizar uma correta estimativa dos benefícios esperados pela política. Grande parte das controvérsias a respeito da utilização da Análise de Custo-Benefício deriva de errôneos cálculos de benefícios através de metodologias que não refletem a disposição da sociedade a pagar pelos resultados esperados das políticas (VISCUSI, 1997).

Desta forma, é notório que a utilização de AIR com uma forte base econômica pode ajudar a responder o Problema estabelecido no Capítulo 1. Dentre as metodologias apresentadas neste capítulo, a Análise de Custo-Benefício se mostrou apropriada para avaliar a adequação dos Aeroportos já construídos aos requisitos de Projeto de Aeródromos estabelecidos pelo RBAC 154, em especial aos requisitos cujos propósitos seriam prover margens de segurança para as operações em situações de contingência (como Faixa de Pista, Distância entre Pista de 
Pouso e Decolagem e Pista de Táxi, e Área de Segurança de fim de Pista - RESA). O mesmo não se aplica aos requisitos que visam à garantia da interoperabilidade, em especial os auxílios visuais à navegação, devido a sua intrínseca necessidade de padronização.

Assim, entende-se que pode ser mais apropriada a utilização da Análise de CustoBenefício para a tomada de decisão da Agência em determinar a adequação de um aeroporto, em substituição ao modelo atual que considera apenas a análise dos riscos. Cabe ressaltar que uma vez valorados os bens não-comercializáveis, em especial o Valor da Vida Humana, a dificuldade de cálculo dos benefícios reside justamente na Análise de Risco já demandada pela ANAC aos Operadores de Aeródromo. Dessa forma, para a elaboração da ACB, os Operadores de Aeródromo necessitariam estimar adicionalmente os custos para adequação dos aeroportos aos requisitos regulamentares, processo do qual os operadores já estão amplamente familiarizados, visto que também são responsáveis pelas construções e expansões dos aeroportos que operam.

Para a utilização da ACB como metodologia de AIR na análise da adequação dos aeroportos aos requisitos de Projeto de Aeródromos no Brasil, foi elaborado o Capítulo 3, em que se apresenta uma revisão bibliográfica do Valor da Vida Humana, bem como calcula-se esse valor para os passageiros da Aviação Civil Brasileira. No Capítulo 4 aplicou-se a metodologia proposta para análise da adequação do Aeroporto de Congonhas. 


\section{VALOR DA VIDA HUMANA}

Discussões sobre o valor de uma vida humana e dos riscos à vida estão entre as mais sensíveis e controversas na economia. Todavia, grande parte das controvérsias deve-se à incompreensão dos principais conceitos que o tema abrange (VISCUSI, 2005).

Segundo Dublin e Lotka (1930), no trabalho intitulado "The money value of a man”, a valoração da vida humana (value upon men) iniciou-se com Sir William Petty no século XVII, tendo sido abordada também por Adam Smith no século XVIII. Porém, o primeiro a utilizar uma abordagem científica ao problema foi Farr (1853), que propôs o cálculo do valor da vida de agricultores baseado em seus fluxos de rendimentos e gastos futuros.

Esse conceito foi utilizado por diversos outros autores, inclusive Dublin e Lotka (1930), que afirmaram que a morte de um homem provoca duas perdas às famílias: a afetiva e a econômica. A primeira seria irreparável, porém certo grau de proteção pode ser provido à segunda. Assim, este primeiro conceito do valor da vida humana foi proposto e utilizado no contexto da reparação às famílias devido a uma morte prematura. Segundo Viscusi et. al. (1992), esse conceito do valor da vida é normalmente utilizado em tribunais, pois reflete a perda financeira da família devido a morte de seu provedor.

Todavia, a utilização desse conceito ao valor da vida humana no contexto de políticas públicas e regulação não é razoável, pois através desta abordagem, pessoas que vivem de transferências, como os beneficiários de programas sociais e os idosos, teriam um valor da vida negativo. Assim, esse conceito praticamente deixou de ser utilizado em trabalhos econômicos, ficando restrito apenas ao cálculo da compensação judicial às famílias.

De acordo com Viscusi (2005), existem dois principais conceitos econômicos para o valor da vida humana: o valor ótimo do ponto de vista dos seguros e o valor necessário para dissuasão (deterrence). Ambos os conceitos endereçam questões diferentes e são pertinentes à promoção de distintos objetivos econômicos.

O princípio básico para o valor ótimo da vida no contexto de seguros é a transferência de renda do estado pré-acidente para o pós-acidente até que a utilidade marginal em ambos os estados se iguale. Todavia, no estado pós-acidente, depois de uma fatalidade ou doença incapacitante, a curva de utilidade é alterada, reduzindo a utilidade e a utilidade marginal para cada nível de renda e fazendo com que um menor nível de renda seja ótimo para o segurado. Dessa forma, é esperado no contexto dos seguros um valor da vida menor. Para o contexto da dissuasão (deterrence), o valor da vida humana é aquele que estabelece os corretos incentivos 
para se evitar que o acidente aconteça. No caso de consequências à saúde, como fatalidades ou incapacitações, o valor ótimo para a dissuasão é superior ao valor calculado para compensação (VISCUSI, 2005).

Segundo Viscusi (2005), a medida econômica do valor ótimo da vida humana para a dissuasão (deterrence) é o tradeoff entre dinheiro e risco considerando riscos muito pequenos de morte. Drèze (1962) propôs inicialmente esse conceito, que ficou amplamente conhecido após o trabalho de Thomas Schelling intitulado "The Life You Save May Be Your Own". Schelling (1968) afirmou que existe uma distinção entre uma vida identificada (individual life) e uma vida não identificada (statistical life): enquanto não faz sentido discutir sobre o valor em salvar uma vida identificada, pois não há como afastar os sentimentos pessoais da análise, as políticas de saúde e de segurança que abordam a morte de forma estatística não precisam evocar tais sentimentos, podendo ser avaliadas da mesma forma que a população avalia se compra ou não alguma commodity. Schelling apresentou também o termo Value of Statistical Life - VSL para o valor da vida humana não identificada (statistical life).

Desde os trabalhos de Drèze e Schelling, o cálculo do VSL tem sido realizado na literatura com base no conceito de disposição a pagar (willingness to pay - WTP) devido a uma pequena redução do risco de morte $(\Delta R)$ através da equação (1).

$$
V S L=\frac{W T P}{\Delta R}
$$

O VSL é atualmente calculado por meio de processos de inferência através de dois modelos que veremos em mais detalhes na sequência: as Preferências Reveladas (PR) e as Preferências Declaradas (PD). Existem ainda diversos modelos teóricos que permitem a análise conceitual e a confirmação teórica de algumas das inferências obtidas nos modelos empíricos.

\subsection{Modelo Teórico}

O modelo teórico que será apresentado neste trabalho corresponde ao primeiro modelo proposto por Drèze (1962), que é utilizado em diversos estudos na literatura de VSL.

Seja a utilidade indireta $V$ de um indivíduo definida pela utilidade de sua sobrevivência $u$ e pela utilidade no caso de seu falecimento (legado à família) $v$ em função de sua riqueza $w$ a probabilidade de sua sobrevivência $p$.

$$
V \equiv p u(w)+(1-p) v(w)
$$


Adotemos as hipóteses de que $u$ e $v$ são duas vezes diferenciáveis, crescentes e quasecôncavas, ou seja:

$$
u^{\prime} \geq 0, v^{\prime} \geq 0, u^{\prime \prime} \leq 0 \text { e } v^{\prime \prime} \leq 0
$$

Assumamos também que a utilidade e utilidade marginal de um indivíduo vivo são maiores do que as do indivíduo falecido.

$$
u>v \text { e } u^{\prime}>v^{\prime}
$$

Através dessas hipóteses é possível desenhar uma curva de indiferença da utilidade indireta em função de $(w, p)$ apresentada na Figura 1.

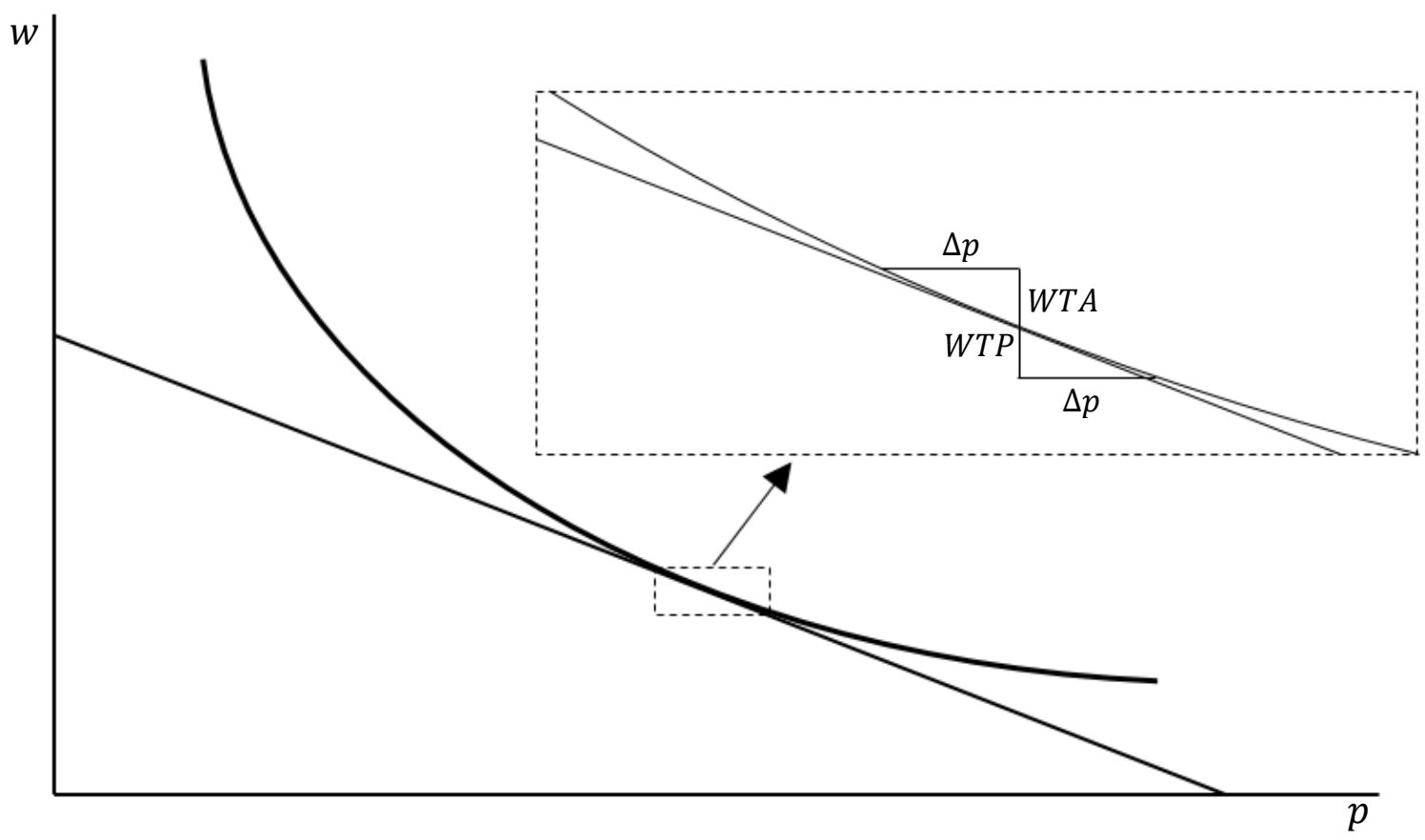

Figura 1 - Curva de isoutilidade indireta

A disposição a pagar WTP e a disposição a aceitar WTA para o aumento da probabilidade de sobrevivência (redução do risco de morte) $\Delta p \equiv \varepsilon$ denotadas por $\operatorname{WTP}(\varepsilon)$ e $W T A(\varepsilon)$ são dadas pelas equações (5) e (6), respectivamente:

$$
\begin{aligned}
& (p+\varepsilon) u(w-W T P(\varepsilon))+(1-p-\varepsilon) v(w-W T P(\varepsilon))=V \\
& (p-\varepsilon) u(w+W T A(\varepsilon))+(1-p+\varepsilon) v(w+W T A(\varepsilon))=V
\end{aligned}
$$

Todavia, utilizando o conceito de Schelling de que o VSL é obtido por pequenas, ou infinitesimais reduções de risco, tem-se que o VSL é igual a Taxa Marginal de Substituição (TMS) entre a riqueza e a probabilidade de sobrevivência. 


$$
\begin{gathered}
V S L=\lim _{\varepsilon \rightarrow 0} \frac{W T P(\varepsilon)}{\varepsilon}=\lim _{\varepsilon \rightarrow 0} \frac{W T A(\varepsilon)}{\varepsilon} \\
V S L \equiv T M S=\frac{-d w}{d p}=\frac{u(w)-v(w)}{p u^{\prime}(w)+(1-p) v^{\prime}(w)}=\frac{u(w)-v(w)}{p\left(u^{\prime}(w)-v^{\prime}(w)\right)+v^{\prime}(w)}
\end{gathered}
$$

Ao se alterar apenas o risco inicial de um indivíduo $(p)$, tem-se:

$$
\frac{\partial V S L}{\partial p} \equiv \frac{v^{\prime}(w)-u^{\prime}(w)}{\left[p\left(u^{\prime}(w)-v^{\prime}(w)\right)+v^{\prime}(w)\right]^{2}}
$$

Como $u^{\prime}>v^{\prime}$ por hipótese, tem-se que:

$$
\frac{\partial V S L}{\partial p}<0
$$

Assim, o modelo teórico apresentado mostra através das equações (8) e (10) que o VSL é sempre positivo e decrescente com a probabilidade inicial de sobrevivência, ou seja, crescente com a probabilidade inicial de morte. Esse efeito foi descoberto por Pratt e Zeckhayser (1996), que o denominou de Dead-Anyway Effect. A sua intuição é que indivíduos com grande chance de morte ( $p$ pequenos) possivelmente não vão comprometer sua riqueza em gastos com a redução da probabilidade de morte, pois estes já se considerariam "mortos de qualquer maneira", ou seja, iriam utilizar a sua riqueza para consumo ou para sucessão.

A influência da renda inicial w do indivíduo pode ser expressa pela equação (11).

$$
\begin{aligned}
\frac{\partial V S L}{\partial w} \equiv \frac{\left(u^{\prime}(w)-v^{\prime}(w)\right) *\left[p u^{\prime}(w)+(1-p) v^{\prime}(w)\right]}{\left[p\left(u^{\prime}(w)-v^{\prime}(w)\right)+v^{\prime}(w)\right]^{2}} \\
-\frac{(u(w)-v(w))\left[p u^{\prime \prime}(w)+(1-p) v^{\prime \prime}(w)\right]}{\left[p\left(u^{\prime}(w)-v^{\prime}(w)\right)+v^{\prime}(w)\right]^{2}}
\end{aligned}
$$

Pelas hipóteses, tem-se que:

$$
\begin{aligned}
u^{\prime}>v^{\prime} & \rightarrow\left(u^{\prime}(w)-v^{\prime}(w)\right)>0 \\
u^{\prime}>v^{\prime} \geq 0 & \rightarrow\left[p u^{\prime}(w)+(1-p) v^{\prime}(w)\right]>0 \\
u>v & \rightarrow(u(w)-v(w))>0 \\
u^{\prime \prime} \leq 0 \text { e } v^{\prime \prime} \leq 0 & \rightarrow(-1)\left[p u^{\prime \prime}(w)+(1-p) v^{\prime \prime}(w)\right]>0
\end{aligned}
$$


Resultando, portanto, em:

$$
\frac{\partial V S L}{\partial w}>0
$$

Assim obtém-se que o VSL calculado pelo WTP para indivíduos mais ricos é superior ao VSL de indivíduos de menor riqueza.

\subsection{Métodos Empíricos}

Existe uma vasta gama de trabalhos empíricos para o cálculo do VSL que segue dois principais métodos: Preferências Reveladas (PR) e Preferências Declaradas (PD).

O método das Preferências Reveladas foi desenvolvido para inferir o VSL que os indivíduos atribuem às suas vidas através de uma redução pequena do risco ao qual elas estão submetidas. As pessoas, mesmo sem perceber, tomam decisões diariamente que envolvem o tradeoff entre dinheiro e risco. Os estudos de PR normalmente focam nas decisões tomadas por indivíduos no mercado de trabalho (salário hedônico), no mercado de consumo (carros com ou sem airbag, uso ou não de capacetes por motociclistas) e no mercado habitacional (bairro/poluição).

O método das Preferências Declaradas consiste em perguntar aos indivíduos o montante que estariam dispostos a pagar WTP (ou a aceitar WTA) para a compensação de uma pequena redução (aumento) no risco ao qual elas estão submetidas. Este método pode ser dividido em duas principais abordagens. A Valoração Contingenciada (VC) é o método direto de entrevista, no qual os indivíduos são questionados sobre qual seria a sua disposição a pagar por um programa público que reduziria o risco de morte da população, ou uma escolha discreta com a simulação de um referendo em que seriam questionados se estariam dispostos ou não a pagar um valor pré-estipulado para a implementação do programa. Outra abordagem, denominada Modelagem de Escolha (ME), consiste em pedir para os indivíduos escolherem entre uma série de opções de custos e riscos à saúde com diferentes características.

Durante muito tempo, o método de cálculo do valor da vida humana pelas PR era considerado o mais confiável, visto que se baseava no comportamento real das pessoas nos mercados, ao contrário de escolhas hipotéticas. Isto pois, no método das PD, os valores declarados pelas pessoas podem ser consideravelmente diferentes daqueles que elas, de fato, pagariam (ou aceitariam) quando confrontadas a uma situação real (OCDE, 2010). 
Todavia, segundo Hammitt e Graham (1999), os estudos de VSL baseados em PR são bastante influenciados pela percepção dos riscos pelos indivíduos, que pode ser muito diferente dos riscos reais aos quais estão submetidos, levando então a valores inconsistentes de WTP e VSL.

Com o avanço dos estudos que utilizam o método das PD e a obtenção de resultados econométricos mais consistentes, observaram-se resultados consideravelmente diferentes, principalmente no tocante ao efeito da renda e da idade do indivíduo na sua disposição a pagar pela redução de risco e, consequentemente, em seu VSL. Os estudos que utilizam os salários hedônicos eram os mais relevantes dentre os de Preferências Reveladas. Esses estudos não possuíam uma variação muito grande nos riscos de mortalidade aos quais os trabalhadores estavam submetidos, e também não possuíam uma variação que cobrisse todo o espectro de renda e de idade da população, sendo, portanto, mais específicos e menos apropriados para avaliar riscos de mortalidade de programas de transporte, ambientais e de saúde, que afetam a população em geral (OCDE, 2010).

\subsection{A Heterogeneidade do VSL}

Segundo Viscusi (2010), o Valor Estatístico da Vida (VSL) não é uma constante. Os tradeoffs entre dinheiro e risco variam de acordo com populações e se alteram com o tempo em virtude da mudança de características econômicas e populacionais. Grande parte dos estudos recentes sobre a heterogeneidade do VSL é motivada pela evolução das estimativas de riscos de morte que permitem a construção de variáveis de risco mais precisas para se medir os riscos que os trabalhadores estão submetidos, levando a resultados econométricos do VSL mais consistentes.

\subsubsection{Resultados dos trabalhos de Preferências Reveladas}

Viscusi e Aldy (2003) realizaram uma extensa revisão da literatura de trabalhos que estimavam o VSL através das Preferências Reveladas, incluindo mais de 30 trabalhos baseados em salários hedônicos do mercado de trabalho norte-americano, 11 estudos do mercado de consumo e mercado habitacional dos Estados Unidos, além de 20 trabalhos de salários hedônicos fora dos Estados Unidos. Foram realizadas várias meta-análises utilizando ferramentas econométricas que confirmam o resultado do efeito renda no Valor Estatístico da Vida mostrado anteriormente no modelo teórico. As meta-analises, todavia, apresentaram que para valores pequenos de risco, o "dead-anyway effect" não pode ser verificado, sendo que o 
VSL reduz com o aumento do risco do cenário base $\frac{\partial V S L}{\partial r}<0$, com a redução cada vez menor com o aumento do risco $\frac{\partial^{2} V S L}{\partial r^{2}}>0$.

Viscusi e Aldy (2003) apresentaram que a elasticidade renda do VSL (em termos de WTP para a redução dos riscos) é em torno de 0,5 a 0,6. Ou seja, os autores mostraram que a aproximação constante da equação (17) pode ser feita para se transferir VSL ao longo do tempo devido à alteração da renda, ou entre países com rendas diferentes (à Paridade do Poder de Compra - PPP) com as demais características constantes.

$$
V S L_{B}=V S L_{A}\left(\frac{Y_{B}}{Y_{A}}\right)^{b}
$$

Onde $V S L_{A}$ é o valor estatístico da vida já estimado em algum estudo anterior, $Y_{A}$ é a renda per capita da população afetada no estudo anterior, $Y_{B}$ é a renda da população per capita que se deseja calcular o $V S L_{B}$ e $b \in[0,5,0,6]$.

Viscusi e Aldy (2003) mostraram que a idade da população afetada possui um considerável efeito no VSL, visto que as análises econométricas demonstraram uma redução do VSL em função da idade, apesar de estudos anteriores, como o de Rosen (1986), mostrarem uma curva do VSL em função da idade da forma de um "U-invertido".

\subsubsection{Resultados dos trabalhos de Preferências Declaradas}

Segundo Viscusi (2010), novos trabalhos que utilizaram as Preferências Declaradas mostraram que o efeito da renda sobre o VSL para a população em geral é maior do que o efeito estimado pelos estudos anteriores de Preferências Reveladas. As novas estimativas para a elasticidade renda do VSL mostram valores do $b$ próximos a 1.0, que segundo o autor são consistentes com modelos teóricos que correlacionam o VSL com o Coeficiente de Aversão Relativa ao Risco (CRRA), apesar da relação entre VSL e a aversão ao risco ser mais complexa do que se pensava antigamente.

Viscusi (2010) afirmou também que os novos estudos de PD mostraram que a influência da idade no VSL não é monotônica. Como as crianças e os idosos estão fora do mercado de trabalho, os estudos de salários hedônicos não avaliavam o VSL para essa parcela da população. Os trabalhos de PD mostram que apesar de o VSL apresentar uma forma de "U-invertido" para a população adulta, o VSL estimado para as crianças é alto, em grande parte devido às preocupações altruístas dos pais em relação aos filhos. 
Lindhjem et. al. (2011) conduziu uma meta-análise dos trabalhos que calcularam o valor estatístico da vida VSL através dos métodos das Preferências Declaradas. A análise econométrica de Lindhjem apresentou a elasticidade renda do VSL $b$ entre 0,7 e 0,9.

\subsection{Organização para a Cooperação e Desenvolvimento Econômico}

A OCDE (2011) publicou o trabalho intitulado Valuing Mortality Risk Reductions In Regulatory Analysis of Environmental, Health and Transport Policies, que além de realizar uma extensa revisão da literatura, propõe metodologias para o estabelecimento do VSL para as políticas de transporte, saúde e meio ambiente baseadas nos valores do VSL já calculados em outros estudos, sejam estes dos mesmos países ou de países diferentes.

São apresentados dois principais métodos:

1. Transferência de Valores Unitários

a. Transferência Unitária Simples;

b. Transferência Unitária com ajuste de renda;

c. Transferência Unitária para grupos distintos de idade.

2. Função de Transferência

a. Função de Transferência de Benefícios;

b. Meta-análise.

O método da Transferência Unitária Simples consiste em utilizar um valor já previamente calculado em outro estudo (ou uma média dos valores de diversos estudos). Essa abordagem presume que o aumento da utilidade (ou do bem-estar social) de uma redução do risco ao qual um indivíduo médio está submetido será igual entre os estudos. Todavia, este método deve ser utilizado com cautela, em especial para a transferência entre países, já que a hipótese do aumento da utilidade do indivíduo médio ser igual é forte, pois ela pode variar devido às características socioeconômicas dos países e devido à magnitude do risco em análise, que pode ser diferente entre as populações.

Caso a transferência seja realizada entre países com diferentes níveis de renda e custos de vida, a Transferência Unitária Simples deve ser descartada. Uma alternativa é a Transferência Unitária com o ajuste de renda, que consiste em utilizar a equação (17). A OCDE sugere a utilização da elasticidade renda do VSL de $0,8(b=0,8)$ calculada por Lindhjem et. al. (2011), bem como a realização de uma análise de sensibilidade. Para a transferência entre 
países, caso o estudo não seja de um grupo da população muito particular, envolvendo uma parcela significativa da população dos países em questão, a relação entre os PIB per capita dos países calculada através da Paridade do Poder de Compra (PPP) pode ser uma boa proxy para a relação entre as rendas das populações afetadas pela política.

Uma vez transferido o VSL, as taxas de câmbio oficiais entre os países não devem ser utilizadas, visto que não refletem a diferença dos poderes de compra, sendo bastante voláteis à alteração de fatores políticos e macroeconômicos. Assim, os valores transferidos devem ser convertidos às moedas locais através das taxas de câmbio ajustadas a PPP.

A OCDE preconiza também que os ajustes de idade sejam feitos caso apenas as populações afetadas pela política sejam muito particulares (ex.: transferência de VSL de um indivíduo médio para um grupo de idosos ou adolescentes), visto os resultados contraditórios que trabalhos acadêmicos apresentaram quanto ao efeito da idade no VSL, e o fato da diferenciação de idade no VSL ser reconhecidamente uma exceção, e não a regra, na análise de políticas públicas.

Os valores de VSL devem ser atualizados no tempo. Na ausência de evidência empírica para um índice de preços mais adequado, os VSL devem ser atualizados pelos índices de preços ao consumidor. A mesma elasticidade renda do VSL utilizada para transferências entre países deve ser utilizada também para a transferência no tempo dos valores de VSL na hipótese de alteração da renda real média da população afetada (ou da alteração real do PIB per capita) ao logo do tempo.

A utilização de Função de Transferência tem conceitual e teoricamente mais apelo do que a Transferência de Valores Unitários, visto que um conjunto maior de informações é efetivamente considerado. Todavia, segundo OCDE (2011) estudos evidenciam que as Funções de Transferência não apresentam, em geral, resultados melhores em termos de erros do que as Transferências de Valores Unitários.

A OCDE sugere, portanto, que a Transferência de Valores Unitários com ajuste de renda é recomendada para a transferência de valores entre países, visto a sua praticidade e transparência, principalmente para estudos em que a população afetada não seja muito particular e que a ordem de grandeza dos riscos envolvidos seja semelhante. 


\subsection{Metodologia Utilizada}

Através da revisão da literatura acadêmica e dos Organismos Internacionais, optou-se pela adoção do método da Transferência de Valores Unitários com ajuste de renda para o cálculo do Valor Estatístico da Vida para o passageiro de transporte regular da Aviação Civil Brasileira.

A partir de uma pesquisa dos valores de VSL declarados pelas Autoridades de Aviação Civil para o transporte regular de passageiros, identificaram-se duas Autoridades que utilizam há algum tempo o VSL obtido através da metodologia da Disposição à Pagar (WTP): As Agências norte-americana FAA (Federal Aviation Administration) e europeia EASA (European Aviation Safety Agency).

A FAA (2015) sugere que as análises conduzidas em 2015 utilizem o valor de 9,4 milhões de dólares para o VSL (calculados para o final de 2014). A EASA e o Eurocontrol, agências europeias de Aviação Civil, utilizam o valor de 2 milhões de euros preconizado pela Comissão Europeia (2009) como input padrão para as Análises de Custo-Benefício.

Como os dois valores de VSL preconizados pelas agências internacionais citadas são específicos para o transporte regular de passageiros, a ordem de grandeza dos riscos aos quais os indivíduos estão submetidos é a mesma para o presente estudo, não sendo necessário nenhum ajuste quanto ao risco.

Não foi utilizado nenhum ajuste quanto à idade, visto que o perfil do passageiro do transporte regular não apresenta uma característica de idade particular que justificasse um ajuste específico.

Para a Transferência de Valores Unitários com ajuste de renda do VSL do passageiro de transporte regular dos Estados Unidos (ano 2015) e da Europa (ano 2009) para o Brasil (ano 2016, calculado para o final de 2015), foi utilizada a transferência em 3 etapas, conforme apresentado na Figura 2. 


\section{1 - Transferência do VSL no Espaço (País A -> Brasil)}

Transferência do VSL do País A, ano X, para o Brasil, ano X, utilizando o ajuste de renda através da relação entre os PIBs per capita à PPP e a elasticidade renda VSL de 0,8 , com análises de sensibilidade para os valores de 0,4 e 1,0 .

\section{2 - Conversão do valor do VSL do Brasil a reais}

Conversão do valor do VSL transferido do país A, ano X, moeda local, para o Brasil, ano $\mathrm{X}$, Real, utilizando a taxa de câmbio ajustada à PPP.

\section{3 - Transferência do VSL do Brasil no Tempo}

Transferência do VSL do Brasil, ano X, para o Brasil, ano Y, utilizando como correção monetária o ICPA, os PIBs per capita a preços constantes e a elasticidade renda VSL de 0,8, com análises de sensibilidade para os valores de 0,4 e 1,0.

Figura 2 - Processo de transferência do VSL em três etapas

A equação de transferência utilizada na etapa 1 é apresentada em (18). Adotou-se a elasticidade renda do VSL de $b$ de 0,8, conforme recomendado pela OCDE (2011), bem como, para as análises de sensibilidade, o valor de 0,4 preconizado pela OCDE (2011) e o valor de 1,0 sugerido por Viscusi (2010).

$$
V S L_{\text {Brasil,ano x }}=V S L_{\text {País A,anox }}\left(\frac{Y_{\text {Brasil,ano } x}}{Y_{\text {País A,anox } x}}\right)^{b}
$$

A equação de transferência do VSL no Brasil ao longo do tempo utilizada na etapa 3 é apresentada em (19). As transferências devem ser feitas com os mesmos valores da elasticidade renda do VSL utilizados na etapa 1.

$$
V S L_{\text {Brasil,ano y }}=V S L_{\text {Brasil,ano } x}\left(\frac{Y_{\text {Brasil,ano } y}}{Y_{\text {Brasil,ano } x}}\right)^{b}
$$


Através da base Stat do OCDE, foram obtidos os valores do PIB per capita à PPP do Brasil, Estados Unidos e Europa, as taxas de câmbio à PPP para o consumo privado do real em função do euro e do real em função do dólar, e o PIB per capita nominal do Brasil. Os valores do IPCA foram obtidos do IBGE. Todos os valores utilizados para o cálculo do VSL estão apresentados no Apêndice A.

Os resultados parciais e finais da transferência do VSL do passageiro de transporte regular dos EUA para o Brasil podem ser visualizados na Tabela 5 e da transferência do VSL do passageiro de transporte regular da Europa para o Brasil na Tabela 6.

Tabela 5 - Transferência do VSL do passageiro dos EUA para o Brasil

\begin{tabular}{ccccc}
\hline Transferência VSL EUA & Moeda & $\mathbf{2 0 1 4}$ & $\mathbf{2 0 1 5}$ \\
\hline Valor Americano & Dólar (milhões) & 9,400 & \\
\hline \multirow{2}{*}{ Etapa 1 } & Cenário 1 (b=0,4) & Dólar (milhões) & 5,844 & \\
& Cenário 2 (b=0,8) & Dólar (milhões) & $\mathbf{3 , 6 3 4}$ & \\
& Cenário 3 (b=1,0) & Dólar (milhões) & 2,865 & \\
Etapa 2 & Cenário 1 (b=0,4) & Reais (milhões) & 10,964 & \\
& Cenário 2 (b=0,8) & Reais (milhões) & $\mathbf{6 , 8 1 7}$ & \\
& Cenário 3 (b=1,0) & Reais (milhões) & 5,375 & \\
Etapa 3 & Cenário 1 (b=0,4) & Reais (milhões) & & 11,795 \\
& Cenário 2 (b=0,8) & Reais (milhões) & & $\mathbf{7 , 1 2 8}$ \\
& Cenário 3 (b=1,0) & Reais (milhões) & & 5,541 \\
\hline
\end{tabular}

Tabela 6 - Transferência do VSL do passageiro da Europa para o Brasil

\begin{tabular}{|c|c|c|c|c|c|c|c|c|c|}
\hline \multicolumn{2}{|c|}{ Transferência VSL Europa } & Moeda & 2009 & 2010 & 2011 & 2012 & 2013 & 2014 & 2015 \\
\hline \multicolumn{2}{|r|}{ Valor Europeu } & Euro (milhões) & 2,000 & & & & & & \\
\hline \multirow{3}{*}{ Etapa 1} & Cenário $1(\mathrm{~b}=0,4)$ & Euro (milhões) & 1,400 & & & & & & \\
\hline & Cenário $2(b=0,8)$ & Euro (milhões) & 0,979 & & & & & & \\
\hline & Cenário 3 (b=1,0) & Euro (milhões) & 0,819 & & & & & & \\
\hline \multirow{3}{*}{ Etapa 2} & Cenário $1(\mathrm{~b}=0,4)$ & Reais (milhões) & 2,711 & & & & & & \\
\hline & Cenário $2(b=0,8)$ & Reais (milhões) & 1,897 & & & & & & \\
\hline & Cenário $3(b=1,0)$ & Reais (milhões) & 1,587 & & & & & & \\
\hline \multirow{3}{*}{ Etapa 3} & Cenário $1(\mathrm{~b}=0,4)$ & Reais (milhões) & & 2,988 & 3,224 & 3,450 & 3,705 & 3,940 & 4,238 \\
\hline & Cenário $2(b=0,8)$ & Reais (milhões) & & 2,177 & 2,378 & 2,574 & 2,803 & 2,978 & 3,114 \\
\hline & Cenário $3(b=1,0)$ & Reais (milhões) & & 1,857 & 2,042 & 2,223 & 2,438 & 2,589 & 2,669 \\
\hline
\end{tabular}


Por fim, foram calculadas as médias dos valores estatísticos da vida transferidos pelo VSL da Europa e dos Estados Unidos. Os resultados são apresentados na Tabela 7.

Tabela 7 - VSL do Passageiro Regular da Aviação Civil Brasileira

\begin{tabular}{cccc}
\hline Cenários & $\begin{array}{c}\text { VSL Brasil } \\
\text { Estimado por VSL Europa } \\
\text { (milhões de reais) }\end{array}$ & $\begin{array}{c}\text { VSL Brasil } \\
\text { Estimado por VSL EUA } \\
\text { (milhões de reais) }\end{array}$ & $\begin{array}{c}\text { VSL Brasil } \\
\text { (milhões de reais) }\end{array}$ \\
\hline Cenário 1 $(\mathrm{b}=0,4)$ & 4,238 & 11,795 & 8,016 \\
Cenário 2 $(\mathbf{b}=\mathbf{0 , 8})$ & $\mathbf{3 , 1 1 4}$ & $\mathbf{7 , 1 2 8}$ & $\mathbf{5 , 1 2 1}$ \\
Cenário 3 $(\mathrm{b}=1,0)$ & 2,669 & 5,541 & 4,105 \\
\hline
\end{tabular}

Assim, o Valor Estatístico da Vida (VSL) estimado para o passageiro de transporte regular da Aviação Civil Brasileira para o ano de 2016 (calculado para o final de 2015) foi de 5,1 milhões de reais, avaliado no cenário da elasticidade renda do VSL de 0,8 proposta por Lindhjem et. al. (2011) e OCDE (2011).

Sugere-se, adicionalmente, a realização de análises de sensibilidade com os VSL de 4,1 milhões de reais (elasticidade renda do VSL 1,0) e 8,0 milhões de reais (elasticidade renda do VSL 0,4).

Caso esses valores venham a ser utilizados em anos posteriores a 2016, a etapa 3 (Transferência do VSL do Brasil no Tempo) deve ser utilizada para a atualização monetária do valor ora calculado e incorporação no VSL de futuras alterações no PIB per capita real. 


\section{ANÁLISE DE CUSTO-BENEFÍCIO DA ADEQUAÇÃO DO AEROPORTO DE CONGONHAS}

A utilização da metodologia de Análise de Custo-Benefício (ACB) para a Análise de Impacto Regulatório (AIR) da adequação de um aeroporto aos requisitos de projeto preconizados pelo Regulamento Brasileiro de Aviação Civil - RBAC 154 enseja vários estudos que visam a quantificar as variáveis que integram os custos e benefícios oriundos da adequação proposta em comparação a outros cenários.

Escolheu-se para análise de caso a adequação do Aeroporto de São Paulo/Congonhas. A Infraestrutura atual do aeroporto pode ser visualizada na Figura 3.

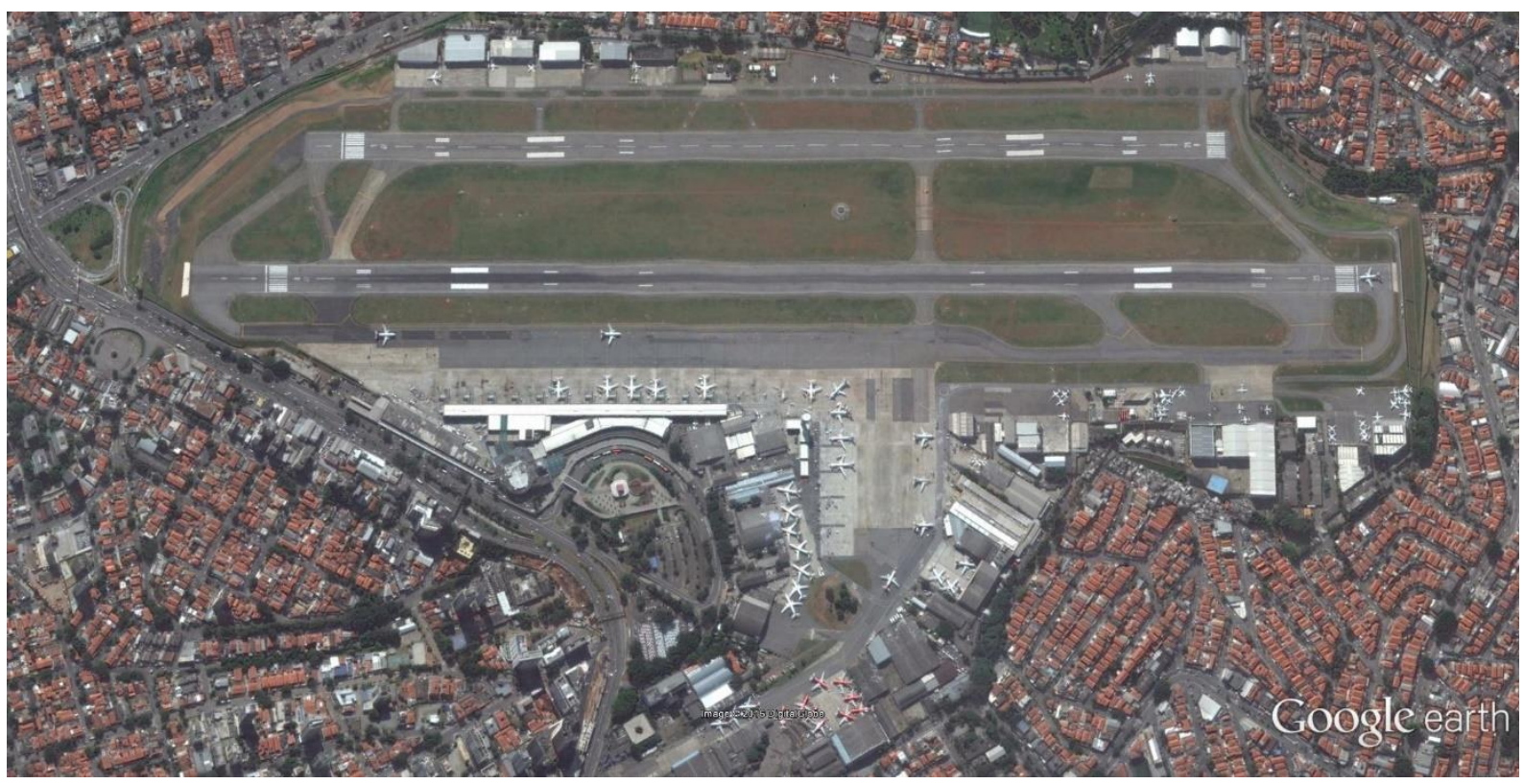

Figura 3 - Fotografia Aérea do Aeroporto de Congonhas

Fonte: Google Earth

De acordo com Infraero (2016), o Aeroporto de Congonhas foi inaugurado no ano de 1936 na região da Vila Congonhas, Distrito de Campo Belo. O projeto da Pista de Pouso e Decolagem, hoje denominada 17R/35L, data da década de 1940, tendo a obra sido concluída no final da década de 1950. Durante a sua execução, o aeroporto operou com uma pista provisória, que mais tarde foi transformada na Pista de Pouso e Decolagem hoje denominada 17L/35R. O Terminal de Passageiros de Congonhas teve a sua última expansão iniciada no ano 2003, onde a Infraero construiu um conector acoplado ao antigo terminal com 12 pontes de embarque para atender às novas áreas de embarque e desembarque. Como consequência da expansão do terminal de passageiros, o aeroporto aumentou o número de pontes de embarque 
e o espaço disponível para o embarque e desembarque de passageiros, melhorando o nível de serviço do terminal de passageiros e aumentando sua capacidade operacional.

Apesar da elevação do nível de serviço alcançado após a expansão, o novo conector avançou sobre o pátio principal do aeroporto, restringindo ainda mais a Área de Movimento do Aeroporto, definida como "parte do aeródromo a ser utilizada para decolagem, pouso e táxi de aeronaves, consistindo na soma da área de manobras e do pátio de aeronaves" (ANAC, 2009).

Como consequência, o espaço existente entre a Pista de Pouso e Decolagem 17R/35L e as pistas de táxi paralelas e posições de estacionamento de aeronaves foi reduzido, como pode ser observado na Figura 4. Dessa forma, a infraestrutura, que já não se conformava às normas preconizadas pela Organização de Aviação Civil Internacional e adotadas no Brasil, se afastou ainda mais dos requisitos técnicos de projeto de aeródromos.

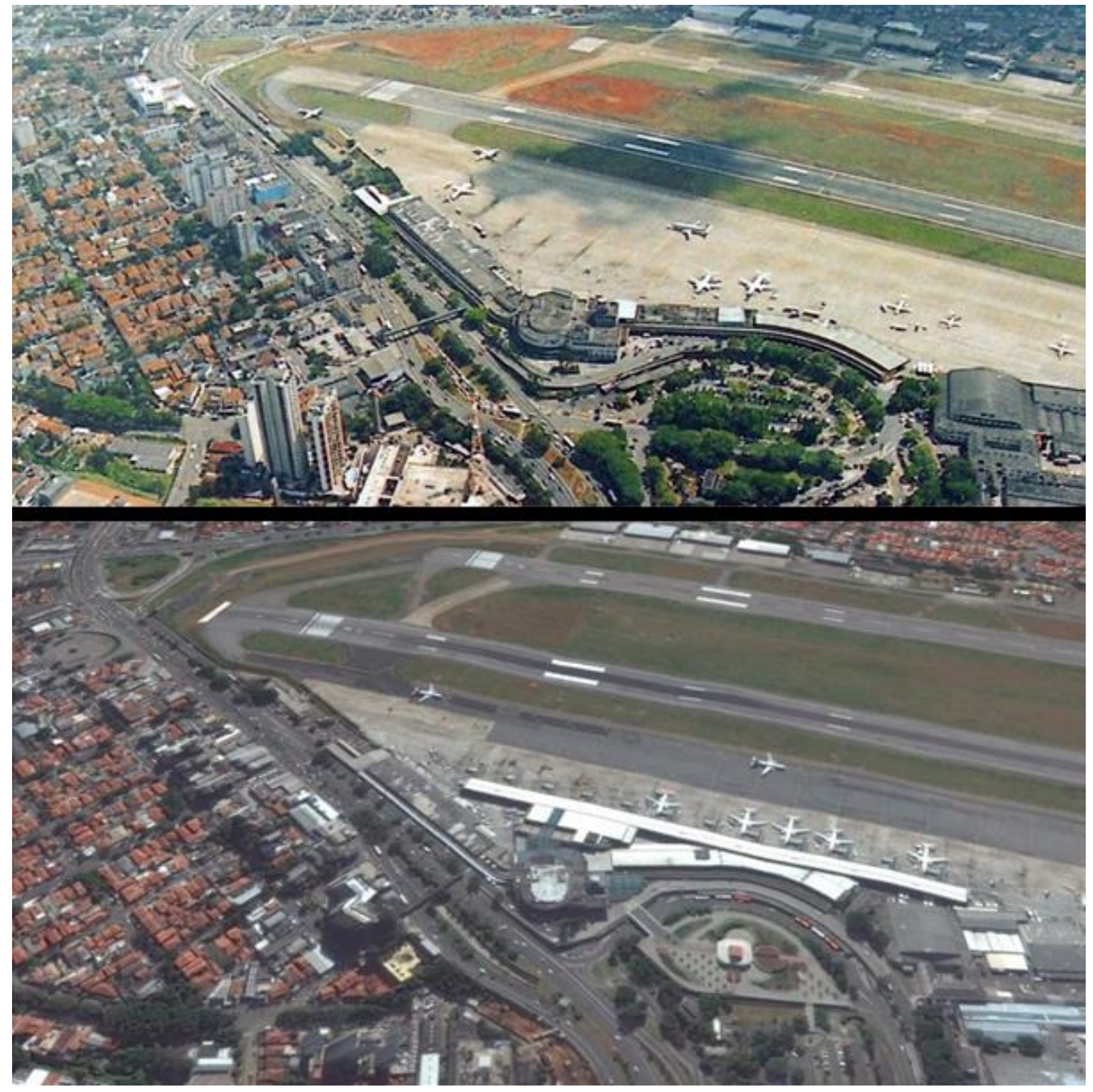

Figura 4 - Pátio principal do Aeroporto de Congonhas antes e depois da expansão de 2003

Fonte: Veja São Paulo e Google Earth 
As principais não conformidades do Aeroporto de Congonhas aos requisitos técnicos de Projeto de Aeródromos preconizados no Brasil pelo Regulamento Brasileiro de Projeto de Aeródromo - RBAC 154 se resumem à:

1. Separação entre a Pista de Pouso e Decolagem 17R/35L à Pistas de Táxi E, M e N e L, conforme Tabela 8;

2. Ausência das Área de Segurança de Fim de Pista (RESA - Runway End Safety Areas).

Tabela 8 - Separação entre as Pistas de Táxi paralelas e a Pista de Pouso Principal

\begin{tabular}{lcccc}
\hline Separação à PPD 17R/35L & TWY E & TWY M & TWY N & TWY L \\
\hline Infraestrutura Atual & $84 \mathrm{~m}$ & $92 \mathrm{~m}$ & $134 \mathrm{~m}$ & $123 \mathrm{~m}$ \\
Requisito de Projeto & $168 \mathrm{~m}$ & $168 \mathrm{~m}$ & $168 \mathrm{~m}$ & $168 \mathrm{~m}$ \\
Violação & $50 \%$ & $45 \%$ & $20 \%$ & $27 \%$ \\
\hline
\end{tabular}

\subsection{Principais incidentes e acidentes no Aeroporto de Congonhas e suas consequências}

Um acidente aeronáutico é definido no Brasil pela NSCA 3-13 como:

Toda ocorrência aeronáutica relacionada à operação de uma aeronave tripulada, havida entre o momento em que uma pessoa nela embarca com a intenção de realizar um voo até o momento em que todas as pessoas tenham dela desembarcado ou, no caso de uma aeronave não tripulada, toda ocorrência havida entre o momento que a aeronave está pronta para se movimentar, com a intenção de voo, até a sua inércia total pelo término do voo, e seu sistema de propulsão tenha sido desligado e, durante os quais, pelo menos uma das situações abaixo ocorra:

a) uma pessoa sofra lesão grave ou venha a falecer como resultado de: - estar na aeronave; - ter contato direto com qualquer parte da aeronave, incluindo aquelas que dela tenham se desprendido; ou - ser submetida à exposição direta do sopro de hélice, de rotor ou de escapamento de jato, ou às suas consequências.

b) a aeronave sofra dano ou falha estrutural que: - afete a resistência estrutural, o seu desempenho ou as suas características de voo; ou - normalmente exija a realização de grande reparo ou a substituição do componente afetado.

c) a aeronave seja considerada desaparecida ou esteja em local inacessível (COMAER, 2013).

A norma supracitada estabelece também o incidente aeronáutico como:

Ocorrência aeronáutica relacionada à operação da aeronave tripulada, havida entre o momento em que uma pessoa nela embarca com a intenção de realizar um voo, até o momento em que todas as pessoas tenham dela desembarcado, que não chegue a se caracterizar como um acidente aeronáutico, mas que afete ou possa afetar a segurança da operação (COMAER, 2013).

A Aeroporto de Congonhas apresenta um considerável histórico recente de incidentes e acidentes aeronáuticos. Foram pesquisados no banco de dados da ANAC e do CENIPA as 
ocorrências em Congonhas de saída de pista por excursão lateral (veer-off) ou por excursão de fim de pista (overrun), que estão apresentadas na Tabela 9.

Tabela 9 - Incidentes e acidentes aeronáuticos em Congonhas com excursão de pista

\begin{tabular}{|c|c|c|}
\hline Data & Classificação & Descrição \\
\hline 04/01/2003 & Incidente & $\begin{array}{l}\text { Aeronave Cessna } 525 \text { CitationJet realizou uma excursão de fim de pista, } \\
\text { precipitou-se no barranco da pista de táxi, ultrapassando a murada do } \\
\text { aeroporto e ferindo pedestre. A aeronave sofreu danos graves, mas seus } \\
\text { ocupantes saíram todos ilesos. }{ }^{1}\end{array}$ \\
\hline $22 / 03 / 2006$ & $\begin{array}{l}\text { Incidente } \\
\text { grave }\end{array}$ & $\begin{array}{l}\text { A aeronave Boeing } 737-400 \text { da empresa BRA, após o pouso na pista } \\
\text { molhada, saiu da pista e parou na borda do desnível existente entre o } \\
\text { sítio aeroportuário e a avenida Washington Luís. }^{2}\end{array}$ \\
\hline 06/10/2006 & Incidente & $\begin{array}{l}\text { A aeronave B } 737-300 \text { da Gol, após o pouso, fez uma excursão lateral de } \\
\text { pista, vindo parar sobre a área gramada próxima à TWY "A". }{ }^{3}\end{array}$ \\
\hline 16/07/2007 & Acidente & $\begin{array}{l}\text { A aeronave ATR } 42-300 \text { da Pantanal, após tocar o solo, deslocou-se para } \\
\text { a esquerda invadindo a área gramada. A aeronave teve danos no trem de } \\
\text { pouso de nariz e na parte inferior da fuselagem. }{ }^{4}\end{array}$ \\
\hline \multirow[t]{3}{*}{$17 / 07 / 2007$} & Acidente & $\begin{array}{l}\text { A Aeronave A320 TAM, voo 3054, durante o pouso perdeu a reta para a } \\
\text { esquerda, vindo a sair da pista lateralmente e a cruzar a Avenida } \\
\text { Washington Luís, colidindo com um prédio no qual funcionava o serviço } \\
\text { expresso de cargas (TAM Express) do próprio operador e um posto de } \\
\text { combustíveis. }\end{array}$ \\
\hline & & $\begin{array}{l}\text { Havia um total de } 187 \text { pessoas a bordo da aeronave, sendo seis tripulantes } \\
\text { ativos e } 181 \text { passageiros (incluindo cinco tripulantes extras e duas crianças } \\
\text { de colo). Todos os passageiros a bordo faleceram. Além dessas, outras } \\
\text { doze pessoas que se encontravam no edifício da TAM Express também } \\
\text { pereceram em decorrência deste acidente. }\end{array}$ \\
\hline & & $\begin{array}{l}\text { A aeronave ficou totalmente destruída como consequência do impacto e } \\
\text { do grande incêndio, que perdurou por muitas horas. O posto de } \\
\text { combustíveis sofreu danos severos na área de sua loja de conveniências e } \\
\text { em alguns veículos lá estacionados. O edifício da TAM Express sofreu } \\
\text { dados estruturais que determinaram sua posterior demolição. }{ }^{5}\end{array}$ \\
\hline 03/09/2008 & Acidente & $\begin{array}{l}\text { Aeronave Beechcraft C } 90 \mathrm{~A} \text { ultrapassou os limites da pista, chocando-se } \\
\text { contra a mureta de proteção, parando sobre o talude lateral do perímetro } \\
\text { do aeroporto, junto à via pública. }{ }^{6}\end{array}$ \\
\hline $11 / 11 / 2012$ & Acidente & $\begin{array}{l}\text { Durante o procedimento de pouso, a aeronave Cessna } 525 \mathrm{~B} \text { Citation } \mathrm{CJ} 3 \\
\text { ultrapassou o final da pista } 35 \mathrm{R} \text { rompendo a cerca operacional e parando } \\
\text { próximo à cerca patrimonial junto à Av. dos Bandeirantes. }{ }^{7}\end{array}$ \\
\hline
\end{tabular}

Esses acidentes despertaram uma preocupação da sociedade e da mídia com relação à segurança apresentada pelo aeroporto. Em especial, após o acidente do voo da TAM 3054 em

\footnotetext{
${ }^{1}$ Fonte: Base de Ocorrências ANAC

${ }^{2}$ Fonte: Base de Ocorrências ANAC e Relatório Final A - No 005/CENIPA/2008.

${ }^{3}$ Fonte: Base de Ocorrências ANAC

${ }^{4}$ Fonte: Base de Ocorrências ANAC e Relatório Final A - No 005/CENIPA/2008.

${ }^{5}$ Fonte: Base de Ocorrências ANAC e Relatório Final A - N ${ }^{\circ}$ 67/CENIPA/2009.

${ }^{6}$ Fonte: Base de Ocorrências ANAC e Relatório Final A - 063/CENIPA/2013

${ }^{7}$ Fonte: Base de Ocorrências ANAC
} 
17 de julho de 2007, em que o avião Airbus A320 ultrapassou o final da Pista de Pouso e Decolagem 35L, colidindo com o prédio da própria empresa TAM e resultando na morte de 199 pessoas, a segurança operacional no Aeroporto de Congonhas ganhou a mídia, com grande repercussão nacional e internacional.

Após este acidente, diversas ações foram tomadas para se elevar o nível de Segurança Operacional no Aeroporto de Congonhas. Dentre elas, destaca-se a redução do comprimento disponível para pousos e decolagens no aeroporto, criando-se então um incremento de segurança no final da pista, já que o comprimento de pista existente é maior do que aquele utilizado para o despacho das aeronaves. Dessa fora, estar-se-ia mitigando o risco relacionado à ausência das Áreas de Segurança de Fim de Pista (RESA).

Outra medida implementada foi a publicação da IAC 121-1013, referente a Procedimentos e Requisitos Técnico-Operacionais Complementares para Operação no Aeroporto de Congonhas, que impõe regras adicionais às empresas aéreas e aos pilotos que operam em Congonhas, além de proibir o transporte regular de passageiros na Pista de Pouso e Decolagem Auxiliar (17L/35R), que possui um menor comprimento e menor margem de segurança operacional (ANAC, 2008).

A principal deficiência da infraestrutura no que tange à Segurança Operacional que não foi mitigada é a separação entre a Pista de Pouso e Decolagem Principal e as Pistas de Táxi paralelas.

Diversos estudos para a adequação do Aeroporto de Congonhas aos requisitos técnicos brasileiros foram elaborados com propostas, por exemplo, da construção de uma nova pista de pouso e decolagem central, paralela às pistas existentes. (RABBANI e MOSER, 2010).

Todavia, as soluções de projeto estudadas são demasiadamente onerosas, não se sabendo se, de fato, os riscos operacionais decorrentes das deficiências da infraestrutura justificariam a sua implantação.

Este capítulo pretende, portanto, utilizar a metodologia de Análise de Custo-Benefício para avaliar a solução que maximiza o bem-estar social da adequação do Aeroporto de Congonhas aos requisitos técnicos de segurança operacional.

Para isso, foram elaborados os seguintes estudos:

1. Quantificação do risco operacional com a infraestrutura existente;

2. Precificação do evento catastrófico; 
3. Estimativa do custo para adequação do aeroporto aos requisitos de projeto;

4. Quantificação do risco operacional com a adequação da infraestrutura aos requisitos de projeto;

5. Análise de custo-benefício da adequação da infraestrutura.

\subsection{Quantificação do risco operacional com a infraestrutura existente}

A IAC 154-1001, Termo de Referência Para Estudo Aeronáutico, estabelece que:

2.1.3 Com relação às características físicas do aeródromo descritas no Anexo 14 da OACI, podem-se identificar recomendações de distâncias e dimensões, entre outras, para as seguintes situações específicas:

(...)b) A largura da faixa de pista ao longo da pista de pouso, que tem por finalidade mitigar os danos às aeronaves que porventura saiam da área pavimentada, ou proteger aeronaves sobrevoando essa faixa durante as decolagens, pousos e decolagens abortadas ou interrompidas, ou em colisões com obstáculos nas saídas laterais durante as operações (DAC, 2004).

Assim, a análise do risco da não-conformidade proveniente da separação entre a pista de pouso e decolagem e as pistas de taxi enseja a quantificação de dois riscos:

- risco de acidente no caso de um desvio lateral da aeronave durante o sobrevoo, ou seja, na fase em que a aeronave ainda não está em contato com a pista de pouso e decolagem, podendo efetuar um procedimento de arremetida;

- risco de acidente no caso de que a aeronave, ao pousar na pista de pouso e decolagem, realizar uma excursão lateral (veer-off), podendo colidir com as aeronaves ou veículos de solo que venham estar nas pistas de táxi paralelas.

Diversas metodologias foram desenvolvidas para quantificar o risco operacional dos Aeroportos. Para o risco específico associado à separação entre a pista de pouso e decolagem e as pistas de táxis paralelas destacam-se os trabalhos de Eddowes et. al. (2001), que foi um dos primeiros estudos que visou a quantificação dos riscos de acidentes durante o pouso e decolagem de aeronaves com o intuito da proposição de novos requisitos de projetos de aeródromos, e Hall et. al. (2011), trabalho intitulado ACRP Report 51: Risk Assessment Method to Support Modification of Airfield Separation Standards, que aprofundou o trabalho de Eddowes permitindo a análise do risco específica para um aeroporto considerando as suas características de infraestrutura, meteorologia e operações. 
O ACRP 51 estabelece que:

A probabilidade da colisão entre aeronaves associada à separação entre as pistas de pouso e decolagem e as pistas de táxi ou objetos depende se a operação é a de pouso ou de decolagem. Para os pousos existem dois tipos de risco que podem ser avaliados:

- Risco durante a aproximação final quando uma aeronave está na fase de sobrevoo e uma combinação de grandes desvios verticais e laterais em relação à trajetória de aproximação prevista pode levar à colisão com objetos fixos ou móveis na área de movimento do aeródromo (i.e., uma aeronave taxiando em uma pista de táxi paralela).

- Risco de uma aeronave perder o controle direcional depois do toque e realizar uma excursão lateral, colidindo com objetos fixos ou móveis na área de movimento do aeródromo.

Esses dois tipos de risco podem ser combinados para prover o risco total para os pousos (Hall et. al. 2011, Tradução própria).

O mesmo documento estabelece que durante uma decolagem os riscos devem ser avaliados apenas para o caso do veer-off, pois no caso de um piloto rejeitar o procedimento de decolagem não há a etapa do sobrevoo como existe no caso do procedimento de aproximação perdida.

Como o ACRP 51 fornece um modelo de análise que avalia os dois riscos provenientes da separação entre a pista de pouso e decolagem e as pistas de taxi, entende-se que esse trabalho atende ao pré-requisito contido na IAC 154-1001. Assim, escolheu-se a metodologia preconizada pelo ACRP 51 para a quantificação do risco de acidente oriundo da proximidade entre as Pistas de Táxi paralelas e a Pista de Pouso e Decolagem 17R/35L.

\subsubsection{Modelo para o risco de acidente durante o sobrevoo}

A Organização de Aviação Civil Internacional - OACI, em conjunto com a FAA (Federal Aviation Adiminstration, autoridade de aviação civil norte-americana), desenvolveu um software denominado CRM, Collision Risk Model, para estimar a probabilidade de colisão de uma aeronave com obstáculos em uma aproximação ILS (Sistema de Aproximação por Instrumento) e em uma eventual aproximação perdida. O CRM constitui a principal ferramenta para estimar a probabilidade de ocorrência de uma colisão durante a fase do sobrevoo. A Figura 5 apresenta um croqui de um procedimento de aproximação perdida na presença de aeronaves na pista de táxi paralela que são consideradas como obstáculos quando a separação entre esta pista de táxi e a pista de pouso e decolagem é inferior aos requisitos técnicos. 


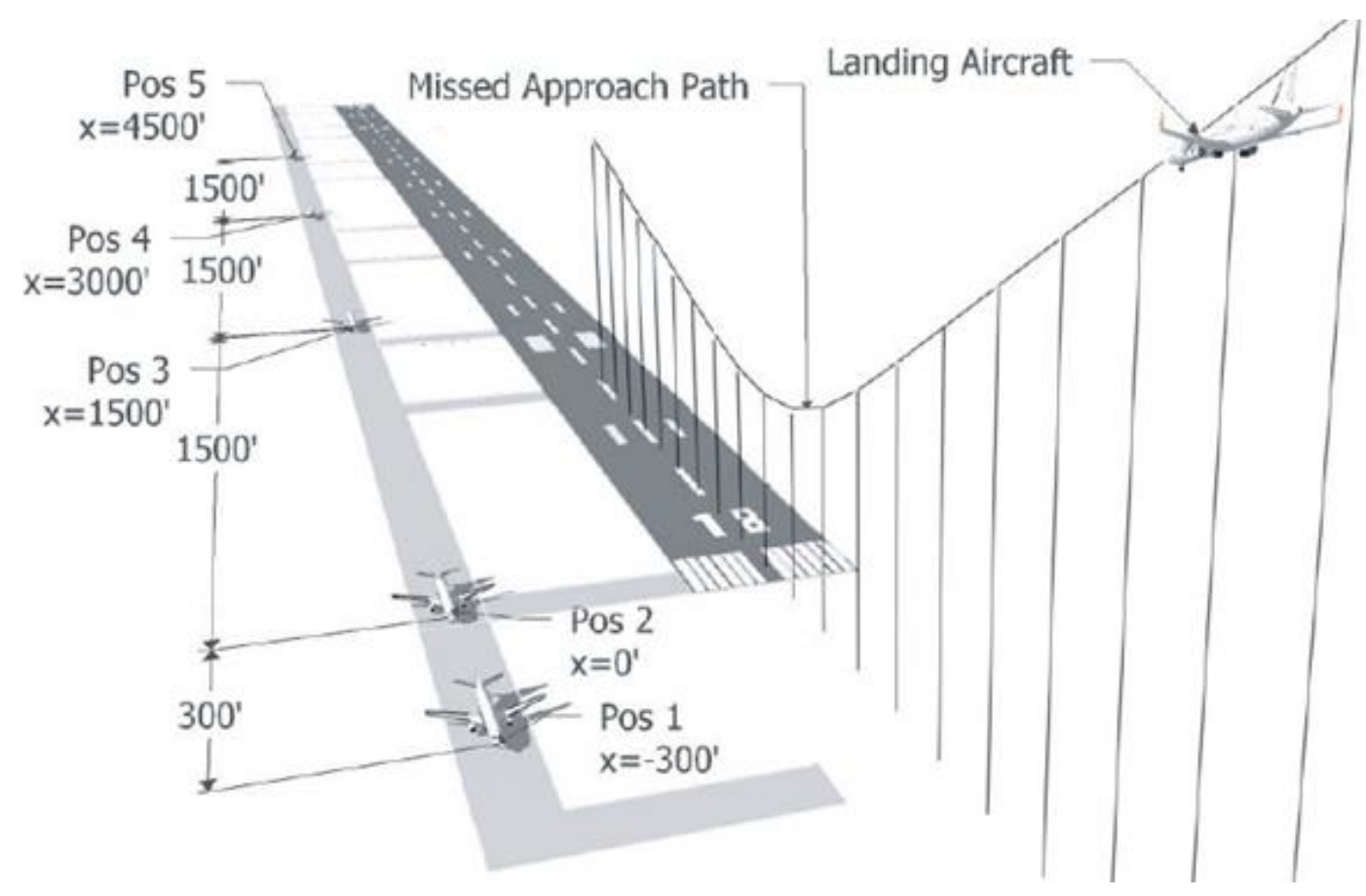

Figura 5 - Croqui de aproximação com procedimento de aproximação perdida e obstáculos Fonte: ACRP 51 (Hall et. al. 2011)

Segundo Hall et. al. (2011), é reconhecido que a análise do CRM demanda a disponibilidade de um software específico e expertise para a sua utilização. Para facilitar a estimativa do risco de acidente durante o sobrevoo, foram realizadas várias análises específicas no CRM para a separação entre as pistas de pouso e decolagem e as pistas de táxi paralelas em várias distâncias e tamanhos de aeronaves diferentes utilizando os limites do ADG, Aerodrome Design Group, que são os códigos utilizados para projeto de aeródromos nos Estados Unidos. Esses códigos são criados para agrupar aeronaves com dimensões e performances semelhantes de tal forma que o projeto dos aeródromos não se dá especificamente para um modelo de aeronave, mas sim pelo ADG da aeronave. Com base nessas análises foram gerados ábacos para a estimativa do risco de acidente durante o sobrevoo em função da separação das pistas de pouso e decolagem e das pistas de táxi paralelas para todos os códigos ADG.

O regulamento brasileiro de Projeto de Aeródromo utiliza um outro tipo de código para o projeto de aeródromo, que é o Código de Referência de Aeródromo, também utilizado no Anexo 14 da OACI (2013). Apesar dos códigos serem diferentes, existe uma forte correlação entre eles, principalmente no que tange às dimensões das aeronaves, fazendo com que seja possível utilizar os ábacos constantes do ACRP 51 para a análise do risco do Aeroporto de Congonhas com base no Código de Referência de Aeródromo 4C, código da aeronave crítica que opera no aeroporto. 
Dessa forma, o risco de acidente durante o sobrevoo para o Aeroporto de Congonhas pode ser estimado pelo ábaco, correspondente ao ADG III para as pistas de aproximação precisão Categoria I, contido na Figura 6. Para cada sentido de pouso da Pista de Pouso e Decolagem 17R/35L considerou-se como obstáculo a pista de táxi paralela mais próxima à sua cabeceira correspondente. Dessa forma, para o pouso pela Pista 17R calculou-se o risco de colisão com aeronaves na Pista de Táxi E (separação 84 metros, ou 275 pés) e para o pouso pela Pista 35L considerou-se o risco de colisão com aeronaves na Pista de Táxi L (separação 123 metros, ou 403 pés).

O risco durante o sobrevoo foi obtido através do ábaco contido na Figura 6 e é apresentado na Tabela 10 .

\section{Missed approach collision risk for ADG III Cat I.}

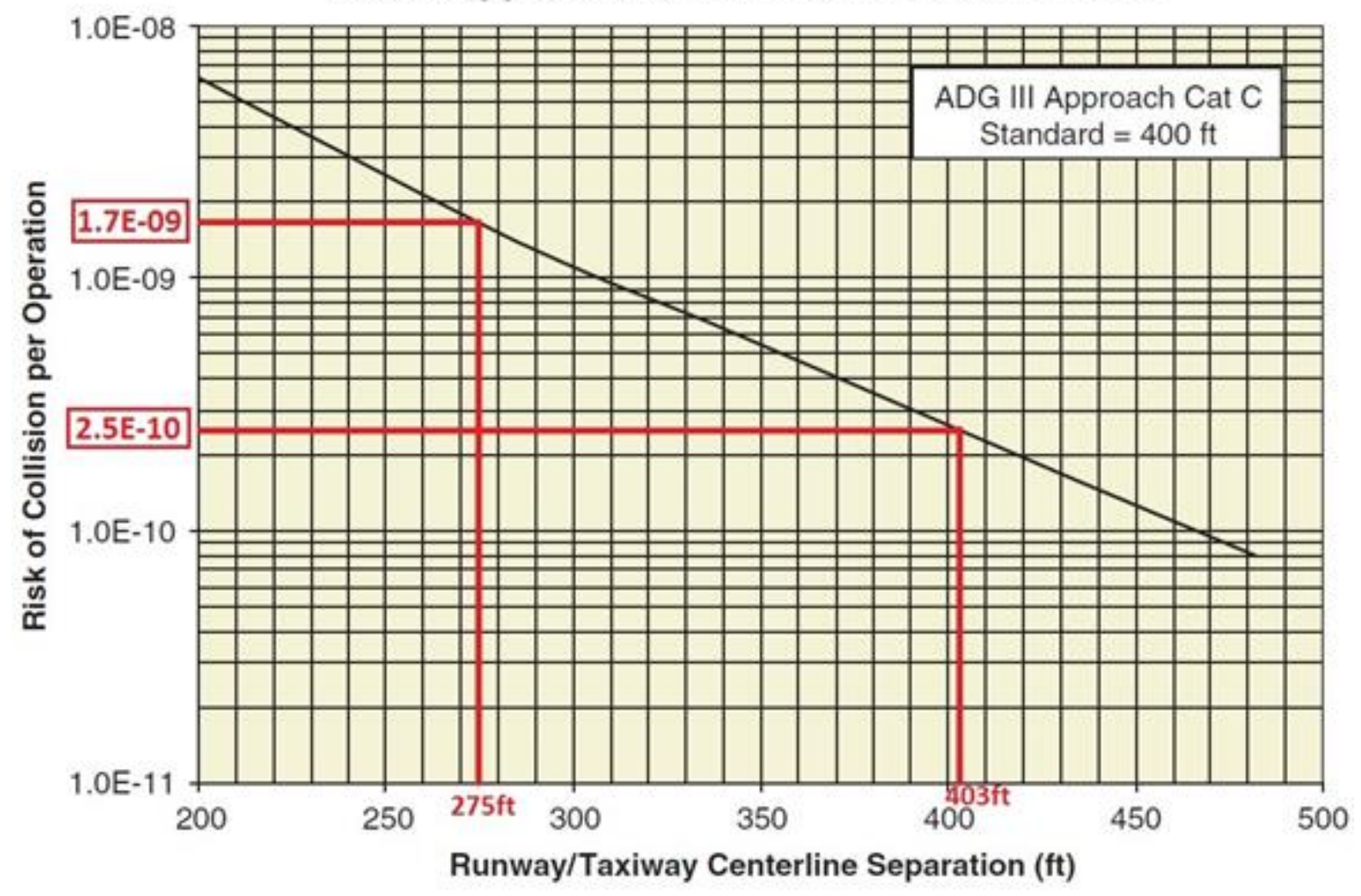

Figura 6 - Ábaco utilizado para estimar o risco de acidente durante o sobrevoo para aeroporto do código de referência de aeródromo 4C e aproximação precisão categoria I

Fonte: Adaptado de ACRP 51 (Hall et. al., 2011)

Tabela 10 - Risco de colisão no sobrevoo para a Pista 17R/35L do Aeroporto de Congonhas

\begin{tabular}{ccc}
\hline Pista & $\mathbf{1 7 R}$ & 35L \\
\hline Risco & $1,7 \times 10^{-9}$ & $2,5 \times 10^{-10}$ \\
\hline
\end{tabular}




\subsubsection{Modelo para o risco de acidente devido a excursões laterais (veer-off)}

Para a estimativa do risco de acidentes de excursões laterais o ACRP 51 utiliza um Modelo de Probabilidade em duas etapas que pode ser visualizado na Figura 7.
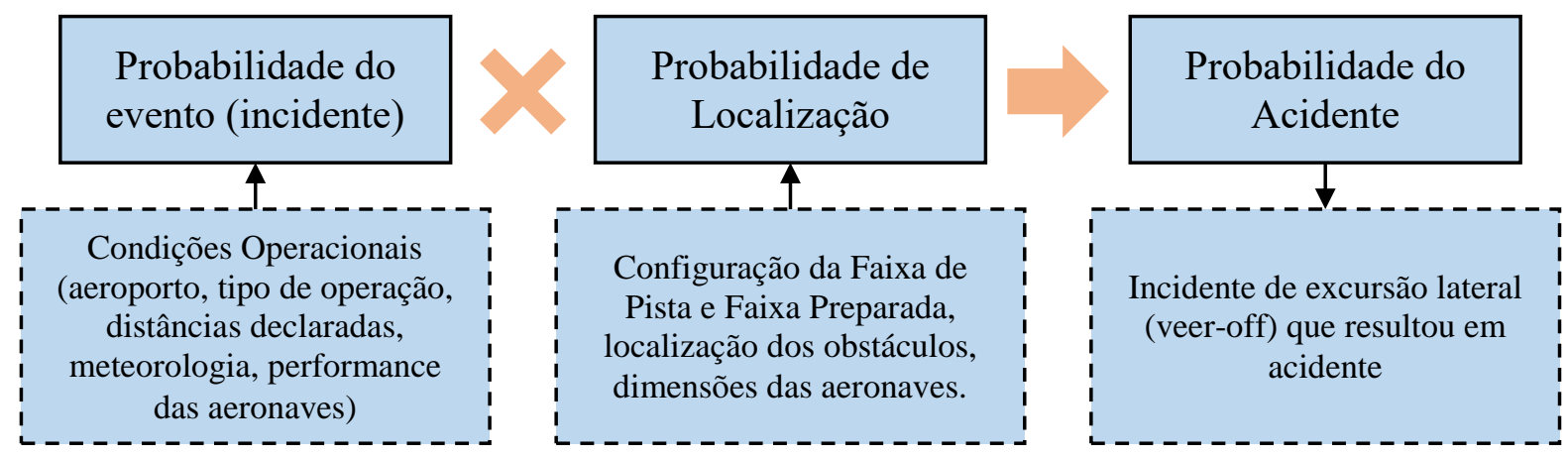

Figura 7 - Modelo de Probabilidade de excursão lateral em duas etapas

Fonte: Adaptado de ACRP 51 (Hall et. al., 2011)

A primeira etapa estima a probabilidade de um evento de excursão lateral, ou seja, a probabilidade de que uma aeronave, ao realizar um procedimento de pouso ou decolagem, tenha uma perda de seu controle direcional e saia da pista. Todavia, caso esta aeronave saia da pista e não colida com nenhum objeto, não resultando em significativos danos estruturais à aeronave ou à perda de vidas humanas, este evento não se classifica como um acidente, e sim como um incidente segundo a NCSA 3-13.

De acordo com o ACRP 51, a probabilidade de um incidente de excursão lateral depende das condições operacionais e de fatores humanos, incluindo características da infraestrutura do aeroporto, condições meteorológicas, performance das aeronaves, bem como da relação entre o comprimento de pista requerido pelas aeronaves e o comprimento de pista disponível no aeroporto.

O ACRP 51 estabeleceu um modelo de regressão logística apresentado na equação (20) que estima o risco de excursão lateral de cada pouso (LDVO - Landing veer-off) e de cada decolagem (TOVO - Takeoff veer-off) realizado em um aeroporto. Para isso, o modelo utiliza 25 variáveis que são obtidas para todos pouso e decolagem no aeroporto durante um período de análise.

$$
P(\text { Incidente })=\frac{1}{1+e^{B X}}
$$

onde $\boldsymbol{B}=\left[\boldsymbol{B}_{\mathbf{0}}, \boldsymbol{B}_{1}, \boldsymbol{B}_{2}, \ldots, \boldsymbol{B}_{25}\right]$ e $\boldsymbol{X}=\left[1, \boldsymbol{X}_{1}, \boldsymbol{X}_{2}, \ldots, \boldsymbol{X}_{25}\right]$. 
As 25 variáveis e os seus respectivos coeficientes utilizados no modelo podem ser visualizados na Tabela 11.

Tabela 11 - Coeficientes das variáveis independentes da regressão logística de probabilidade de excursão lateral

\begin{tabular}{|c|c|c|}
\hline Variáveis & LDVO & TOVO \\
\hline Constant & $-13,088$ & $-15,612$ \\
\hline User Class G & 1,682 & 2,094 \\
\hline Aircraft Class A/B & $-0,770$ & $-0,852$ \\
\hline Aircraft Class D/E/F & $-0,252$ & $-0,091$ \\
\hline Visibility less than 2 SM2 & 2,143 & 2,042 \\
\hline Visibility from 2 to $4 \mathrm{SM}$ & 0,000 & 0,808 \\
\hline Visibility from 4 to $8 \mathrm{SM}$ & 0,000 & $-1,500$ \\
\hline Xwind from 5 to $12 \mathrm{kt}$ & 0,653 & 0,102 \\
\hline Xwind from 2 to $5 \mathrm{kt}$ & $-0,091$ & 0,000 \\
\hline Xwind more than $12 \mathrm{kt}$ & 2,192 & 0,706 \\
\hline Tailwind from 5 to $12 \mathrm{kt}$ & 0,066 & 0,000 \\
\hline Tailwind more than $12 \mathrm{kt}$ & 0,980 & 0,000 \\
\hline Temp less than $5^{\circ} \mathrm{C}$ & 0,558 & 0,988 \\
\hline Temp from 5 to $15^{\circ} \mathrm{C}$ & $-0,453$ & $-0,420$ \\
\hline Temp more than $25^{\circ} \mathrm{C}$ & 0,291 & $-0,921$ \\
\hline Icing Conditions & 2,670 & 0,000 \\
\hline Rain & $-0,126$ & $-1,541$ \\
\hline Snow & 0,548 & 0,963 \\
\hline Frozen Precipitation & $-0,103$ & 0,000 \\
\hline Gusts & $-0,036$ & 0,000 \\
\hline Fog & 1,740 & 0,000 \\
\hline Turboprop & $-2,517$ & 1,522 \\
\hline Foreign Origin/Destination & $-0,334$ & $-0,236$ \\
\hline Hub/Non-Hub Airport & 0,000 & $-0,692$ \\
\hline Log Criticality Factor & 4,318 & 1,707 \\
\hline Night Conditions & $-1,360$ & 0,000 \\
\hline
\end{tabular}

Fonte: ACRP 51 (Hall et. al., 2011)

As 25 variáveis independentes utilizadas foram definidas com base nas regras contidas da Tabela 12 . 
Tabela 12 - Definição das variáveis do modelo de probabilidade de excursão lateral

\begin{tabular}{|c|c|}
\hline Variável & Referência \\
\hline User Class G & $\mathrm{Xi}=1$ se for Aviação Geral ou $\mathrm{Xi}=0$ para demais operações \\
\hline Aircraft Class A/B & $\begin{array}{l}\mathrm{Xi}=1 \text { se a classe das aeronaves for } \mathrm{A} \text { ou } \mathrm{B}, \mathrm{e} \mathrm{Xi}=0 \text { se a classe for } \mathrm{C}, \mathrm{D}, \mathrm{E} \text { ou } \\
\mathrm{F} \text {. }\end{array}$ \\
\hline Aircraft Class D/E/F & $\begin{array}{l}\mathrm{X}=1 \text { se a classe das aeronaves for } \mathrm{D}, \mathrm{E} \text { ou } \mathrm{F} \text {, e } \mathrm{Xi}=0 \text { se a classe for } \mathrm{A}, \mathrm{B} \text { ou } \\
\mathrm{C} \text {. }\end{array}$ \\
\hline Visibility less than $2 \mathrm{SM}$ & $\begin{array}{l}\mathrm{X}=1 \text { se a visibilidade for menor do que } 2 \text { milhas náuticas e } \mathrm{Xi}=0 \text { caso } \\
\text { contrário. }\end{array}$ \\
\hline Visibility from 2 to $4 \mathrm{SM}$ & $\begin{array}{l}\mathrm{Xi}=1 \text { se a visibilidade for maior ou igual a } 2 \text { e menor do que } 4 \text { milhas } \\
\text { náuticas e } \mathrm{Xi}=0 \text { caso contrário. }\end{array}$ \\
\hline Visibility from 4 to $8 \mathrm{SM}$ & $\begin{array}{l}\mathrm{X}=1 \text { se a visibilidade for maior ou igual a } 4 \text { e menor do que } 8 \text { milhas } \\
\text { náuticas e } \mathrm{Xi}=0 \text { caso contrário. }\end{array}$ \\
\hline Xwind from 5 to $12 \mathrm{kt}$ & $\begin{array}{l}\mathrm{Xi}=1 \text { se a o vento de través for maior do que } 5 \text { e menor ou igual a } 12 \text { nós e } \\
\mathrm{Xi}=0 \text { caso contrário. }\end{array}$ \\
\hline Xwind from 2 to $5 \mathrm{kt}$ & $\begin{array}{l}\mathrm{Xi}=1 \text { se a o vento de través for maior do que } 2 \text { e menor ou igual a } 5 \text { nós e } \\
\mathrm{Xi}=0 \text { caso contrário. }\end{array}$ \\
\hline Xwind more than $12 \mathrm{kt}$ & $\mathrm{Xi}=1$ se o vento de través for maior do que 12 nós e $\mathrm{Xi}=0$ caso contrário. \\
\hline Tailwind from 5 to $12 \mathrm{kt}$ & $\begin{array}{l}\mathrm{Xi}=1 \text { se o vento de cauda for maior do que } 5 \text { e menor ou igual a } 12 \text { nós e } \\
\mathrm{Xi}=0 \text { caso contrário. }\end{array}$ \\
\hline Tailwind more than $12 \mathrm{kt}$ & $\mathrm{Xi}=1$ se o vento de cauda for maior do que 12 nós e $\mathrm{Xi}=0$ caso contrário. \\
\hline Temp less than $5^{\circ} \mathrm{C}$ & $\mathrm{Xi}=1$ se a temperatura for inferior a $5^{\circ} \mathrm{C}$ e $\mathrm{Xi}=0$ caso contrário \\
\hline Temp from 5 to $15^{\circ} \mathrm{C}$ & $\begin{array}{l}\mathrm{Xi}=1 \text { se a temperatura for igual ou superior a } 5^{\circ} \mathrm{C} \text { e menor do que } 15^{\circ} \mathrm{C} \mathrm{e} \\
\mathrm{Xi}=0 \text { caso contrário }\end{array}$ \\
\hline Temp more than $25^{\circ} \mathrm{C}$ & $\mathrm{Xi}=1$ se a temperatura for superior a $25^{\circ} \mathrm{C}$ e $\mathrm{Xi}=0$ caso contrário \\
\hline Icing Conditions & $\mathrm{Xi}=1$ operação com presença de gelo na pista e $\mathrm{Xi}=0$ caso contrário \\
\hline Rain & $\mathrm{Xi}=1$ operação com em condição de chuva e $\mathrm{Xi}=0$ caso contrário \\
\hline Snow & $\mathrm{Xi}=1$ operação em condição de neve e $\mathrm{Xi}=0$ caso contrário \\
\hline Frozen Precipitation & $\mathrm{Xi}=1$ operação em condição de chuva de granizo $\mathrm{Xi}=0$ caso contrário \\
\hline Gusts & $\mathrm{Xi}=1$ operação em condição de ventos de rajada e $\mathrm{Xi}=0$ caso contrário \\
\hline Fog & $\mathrm{Xi}=1$ operação em condição de neblina e $\mathrm{Xi}=0$ caso contrário \\
\hline Turboprop & $\mathrm{Xi}=1$ operação com aeronaves turboélice e $\mathrm{Xi}=0$ caso contrário \\
\hline Foreign Origin/Destination & $\mathrm{Xi}=1$ operações internacionais e $\mathrm{Xi}=0$ operações domésticas \\
\hline Hub/Non-Hub Airport & $\mathrm{Xi}=1$ para aeroportos $\mathrm{HUB}$ e $\mathrm{Xi}=0$ caso contrário \\
\hline Log Criticality Factor & $\begin{array}{l}\text { Logaritmo na base } 10 \text { do (comprimento de pista requerido pela aeronave } \\
\text { corrigido em função da elevação do aeródromo, temperatura, vento de cauda } \\
\text { e condição de superfície do pavimento dividido pelo comprimento de pista } \\
\text { disponível) }\end{array}$ \\
\hline Night Conditions & $\mathrm{Xi}=1$ para operações noturnas e $\mathrm{Xi}=0$ caso contrário \\
\hline
\end{tabular}

Fonte: Adaptado de ACRP 51 (Hall et. al., 2011). 
A segunda etapa da análise estima a probabilidade de uma excursão lateral chegar até a um certo ponto $y$ (distância longitudinal ao eixo da pista de pouso e decolagem) através da equação (21). Esta é a probabilidade condicional do acidente, dado que o incidente (excursão lateral) já aconteceu, ou seja, a probabilidade de ocorrer danos estruturais às aeronaves ou resultar na perda de vidas humanas.

$$
P(\text { Acidente } / \text { Incidente })=P(\text { Localização }>y)=e^{-b y^{m}}
$$

Os coeficientes da equação (21) são apresentados na Tabela 13.

Tabela 13 - Coeficientes do modelo de probabilidade de localização

Fonte: ACRP 51 (Hall et. al., 2011).

\begin{tabular}{ccc}
\hline Tipo de Acidente & Coeficiente b & Coeficiente $\mathbf{m}$ \\
\hline LDVO & $-0,02568$ & 0,803946 \\
TOVO & $-0,01639$ & 0,863461 \\
\hline
\end{tabular}

Assim, a probabilidade do acidente é determinada pelo produto das probabilidades calculadas através das etapas 1 e 2 de acordo com a equação (22).

$$
P(\text { Acidente })=P(\text { Incidente }) * P(\text { Acidente } / \text { Incidente })
$$

Uma vez estabelecido este modelo, o ACRP propõe duas alternativas para estimar o risco do acidente. A primeira utiliza como $P$ (Incidente) o dado histórico das ocorrências de excursões laterais passadas nos Estados Unidos. Dessa forma, esta alternativa não demanda dados específicos de operação e meteorológicos do aeroporto, sendo necessário apenas a definição de quais obstáculos serão considerados nesta análise. A segunda alternativa prevista no ACRP envolve a utilização do modelo de probabilidade de excursão lateral que utiliza a regressão logística apresentada na etapa 1, sendo esta mais precisa, já que estima a probabilidade do evento acontecer em um dado aeroporto em função das suas características operacionais e meteorológicas específicas.

De acordo com o a IAC 154-1001:

\section{A1.5 - CONSIDERAÇÕES RELATIVAS A EXIGÊNCIAS FUNCIONAIS} ESPECÍFICAS

Distâncias de Separação Pista de Pouso/Pista de Táxi

O principal aspecto exigindo considerações diz respeito à proteção de uma aeronave que inadvertidamente sai da pista de pouso, vindo a colidir com outra aeronave taxiando em uma pista de táxi paralela. O risco de ocorrer uma colisão é essencialmente determinado pela: 
a) probabilidade de a aeronave sair da pista; e

b) exposição aos riscos de colisão.

Esses fatores teriam que ser avaliados através de um estudo para o ambiente operacional específico existente no aeródromo de interesse (DAC, 2004).

Dessa forma, a segunda alternativa do ACRP 51 é a única aderente à norma brasileira, pois possibilita a estimativa da probabilidade da aeronave sair da pista através do ambiente operacional (operação e meteorologia) específico do aeroporto com base nos dados reais das operações de Congonhas.

Para esta alternativa, o ACRP 51 prevê que o risco é estimado através do seguinte procedimento.

1. Obtenção de um ano de dados históricos de operação e informação das condições meteorológicas do aeroporto;

2. Cálculo da probabilidade de excursões laterais utilizando o Modelo de Frequência;

3. Cálculo da probabilidade de uma aeronave, ao realizar uma excursão lateral, chegue a colidir com o obstáculo em análise, no caso uma aeronave ou veículos nas pistas de táxi paralelas;

4. Multiplicar a probabilidade do Modelo de Frequência à probabilidade do Modelo de Localização para cada movimento de pouso e decolagem.

5. Calcular a média dos valores de probabilidade para as operações de pouso e para as operações de decolagem (Hall et. al., 2011, Tradução própria).

Os dados das operações do Aeroporto de Congonhas foram obtidos pelo BIMTRA (Banco de Informações de Movimento de Tráfego Aéreo), banco de dados do Comando da Aeronáutica. Para cada movimento do aeroporto (pouso ou decolagem) foram obtidos o número do voo, a matrícula da aeronave, o aeroporto de partida, o aeroporto de destino, o código da aeronave, o tipo de voo (regular, aviação geral, militar, táxi aéreo/fretamento), a regra de voo do aeródromo, a regra de voo da aeronave, a pista de pouso e decolagem utilizada e o horário do movimento (ano, mês, dia, hora e minuto).

Foi escolhido para a análise o ano de 2015. O BIMTRA forneceu uma lista de 217.219 movimentos para o aeroporto. Os dados receberam os seguintes tratamentos:

- Foram excluídas 14.354 operações de aeronaves de asas rotativas (helicópteros), visto que a análise de risco é específica para a operação de asas fixas (aviões);

- Foram excluídas 16.716 operações da pista de pouso 17L/35R (auxiliar), pois o escopo de análise é apenas a pista de pouso 17R/35L (principal); 
- Foram encontradas 1549 operações que informavam uma pista de pouso e decolagem que não existe em Congonhas, o que mostra que a base BIMTRA possui algumas informações inconsistentes. Esses dados foram ajustados com base na operação cronologicamente anterior que possuía o dado correto da pista de pouso e decolagem, respeitando a restrição da IAC 121-1013 que proíbe o transporte regular de passageiros na pista de pouso 17L/35R (auxiliar);

- 220 operações informavam códigos de aeronaves que não existiam. Foi consultado o RAB (Registro Aeronáutico Brasileiro) para determinar, com base na matrícula da aeronave, qual era o seu modelo;

- Por fim, foram excluídas 20 operações que possuíam erros/inconsistências que não permitiram o seu tratamento.

Assim, a base de dados final de operações de aeronaves na Pista de Pouso e Decolagem 17R/35L para o ano de 2015 ficou com 186.129 operações de pousos e decolagens de aeronaves de asas fixas.

Para a estimativa do risco do acidente são necessários diversos dados das aeronaves, dos quais destacam-se os dados de dimensões (envergadura) e performance (distância de pouso e de decolagem considerando os pesos máximos da aeronave). Foram utilizados os dados contidos no Apêndice F do ACRP 51.

Contudo, 3049 operações encontradas no Aeroporto de Congonhas eram de aeronaves não constantes desse apêndice. Assim, essas aeronaves foram ajustadas por outras de dimensões e performances similares conforme apresentado na Tabela 14.

Tabela 14 - Ajuste das aeronaves não constantes do Apêndice F do ACRP 51

\begin{tabular}{lllcc}
\hline $\begin{array}{l}\text { Código } \\
\text { Aeronave }\end{array}$ & Fabricante & Modelo & $\begin{array}{c}\text { Código } \\
\text { Aeronave } \\
\text { Ajustada }\end{array}$ & $\begin{array}{c}\text { Número de } \\
\text { ocorrências }\end{array}$ \\
\hline AB11 & Aero Boero & AB-115 & C120 & 2 \\
AC90 & Gulfstream Aerospace & Jetprop Commander 900 & C550 & 10 \\
C25C & Cessna & Citation CJ4 & C25B & 107 \\
C510 & Cessna & Citation Mustang & C501 & 110 \\
C680 & Cessna & Citation Sovereign & C650 & 363 \\
CL30 & Bombardier & Challenger 300 & CL60 & 99 \\
CN35 & Casa & CN-235 & C212 & 9 \\
COL3 & Cessna & Corvalis & C401 & 1
\end{tabular}




\begin{tabular}{lllcc} 
COL4 & Cessna & Corvalis TT & C401 & 2 \\
DHC6 & De Havilland Canada & UV-18 Twin Otter & DCH5 & 1 \\
E121 & Embraer & Xingu & E120 & 5 \\
E35L & Embraer & VC-99B Legacy 600 & CL60 & 34 \\
E50P & Embraer & EMB-500 Phenom 100 & C501 & 918 \\
E550 & Embraer & EMB-550 Legacy 500 & CL60 & 42 \\
E55P & Embraer & EMB-505 Phenom 300 & C25B & 875 \\
FA7X & Dassault & Falcon 7X & CL60 & 249 \\
G150 & Gulfstream Aerospace & Gulfstream G150 & GLF2 & 107 \\
G280 & gulfstream Aerospace & Gulfstream G280 & GLF2 & 36 \\
GLF6 & Gulfstream Aerospace & Gulfstream G650 & GLF5 & 2 \\
LJ40 & Learjet & 40 & LJ45 & 27 \\
P28B & Icsa & PA-28-235 Cherokee Pathfinder & P28R & 1 \\
PAY1 & Chincul & PA-A-31T1-500 Cheyenne 1 & PA31 & 20 \\
SR20 & Cirrus & T-53 & C210 & 2 \\
SR22 & Cirrus & SR-22 & C210 & 25 \\
TUCA & Embraer & T-27 Tucano & C210 & 2 \\
\hline Total & & & & $\mathbf{3 0 4 9}$ \\
\hline
\end{tabular}

Os dados meteorológicos foram extraídos da RedeMet, base que consolida as informações METAR (Meteorological Aerodrome Report), que é uma codificação das informações meteorológicas de um dado aeroporto. Foram considerados todos os METAR regulares, ou seja, as informações horárias, bem como os METAR especiais confeccionados quando há uma mudança brusca das condições meteorológicas durante o intervalo da hora, por exemplo pelo início de uma chuva ou alguma outra informação importante.

Para cada uma das 186.129 operações de pouso e decolagem estabeleceu-se a meteorologia naquele momento através da base METAR ao se considerar o primeiro código METAR, regular ou especial, anterior ao horário da operação. Através desta última base, para cada operação de pouso e decolagem foram calculadas as 25 variáveis necessárias para a regressão logística do modelo de frequência do incidente e estimou-se a probabilidade da ocorrência de uma excursão lateral durante a operação por operação $P$ (Incidente) através da equação (20).

Para cada operação foi calculada a probabilidade desta aeronave, no caso de realizar uma excursão lateral, colidir com uma aeronave (ou veículo) taxiando pelas pistas de táxi E, M, $\mathrm{N}$ e L. Assim, através da equação (21), obteve-se $P$ (Acidente/Incidente) para cada um dos 
pousos e decolagens considerados nesta análise. Como o modelo do ACRP 51 permite a consideração de apenas uma pista de táxi paralela, considerou-se a Pista de Táxi M ("Mike"), visto que esta é a que possui maior comprimento, além de ser a mais central, posição em que se verificam as principais ocorrências de ver-off. Foi considerado que existem apenas obstáculos à faixa de pista de um lado da pista de pouso e decolagem, considerando que o outro lado da pista é livre de obstáculos, ou seja, faixa de pista de 150 metros preservada. Assumiu-se adicionalmente que o risco das aeronaves terem uma excursão lateral é igual para ambos os lados da pista de pouso e decolagem.

Por fim, foi calculada a probabilidade $P$ (Acidente) através de equação (22) individualmente das 186.129 operações. O resumo dos resultados é apresentado na Tabela 15.

Tabela 15 - Probabilidade de excursões laterais para o Aeroporto de Congonhas

\begin{tabular}{lccc}
\hline Probabilidade do Acidente & 17R & 35L & Total \\
\hline LDVO & $5,590 \mathrm{E}-07$ & $6,907 \mathrm{E}-07$ & $6,159 \mathrm{E}-07$ \\
TOVO & $1,167 \mathrm{E}-08$ & $6,989 \mathrm{E}-09$ & $9,587 \mathrm{E}-09$ \\
\hline Total & $\mathbf{2 , 9 2 7 E - 0 7}$ & $\mathbf{3 , 4 9 2 E - 0 7}$ & $\mathbf{3 , 1 7 5 E - 0 7}$ \\
\hline
\end{tabular}

\subsubsection{Risco total associados às pistas de táxi paralelas}

O risco total associado às pistas de táxi paralelas em Congonhas para as operações de pouso é a soma do risco de LDVO ao risco de colisão no sobrevoo, enquanto o risco para as operações de decolagem é apenas o risco de TOVO. Os valores do risco total associados à separação das pistas de táxi paralelas estimados para o Aeroporto de Congonhas podem ser observados na Tabela 16.

Tabela 16 - Probabilidade de acidente no Aeroporto de Congonhas associado à separação das Pistas de Táxi paralelas

\begin{tabular}{lccc}
\hline Probabilidade do Acidente & $\mathbf{1 7 R}$ & $\mathbf{3 5 L}$ & Total \\
\hline Pouso & $5,593 \mathrm{E}-07$ & $6,924 \mathrm{E}-07$ & $6,167 \mathrm{E}-07$ \\
Decolagem & $1,167 \mathrm{E}-08$ & $6,989 \mathrm{E}-09$ & $9,587 \mathrm{E}-09$ \\
\hline Total & $\mathbf{2 , 9 2 9 E - 0 7}$ & $\mathbf{3 , 5 0 0 E - 0 7}$ & $\mathbf{3 , 1 7 9 E - 0 7}$ \\
\hline
\end{tabular}

Percebe-se então que o risco médio das operações de pouso é $6,167 \times 10^{-7}$ e o risco médio das operações de decolagem é 9,587 $\times 10^{-9}$. Ao analisar os riscos à luz do critério de referência da IAC154-1001 de 1,0x10-7, também chamado de TLS (Target Level of Safety), percebe-se que os pousos no Aeroporto de Congonhas possuem um risco mais do que 6 vezes superior ao TLS. O risco médio das operações é $3,179 \times 10^{-7}$, portanto mais do que 3 vezes superior ao TLS. 
A distribuição dos riscos de pouso e decolagem podem ser observadas nas Figura 8 e Figura 9. A região sombreada vermelho claro possui o risco acima de $1,0 \times 10^{-7}$, ou seja, superior ao TLS.

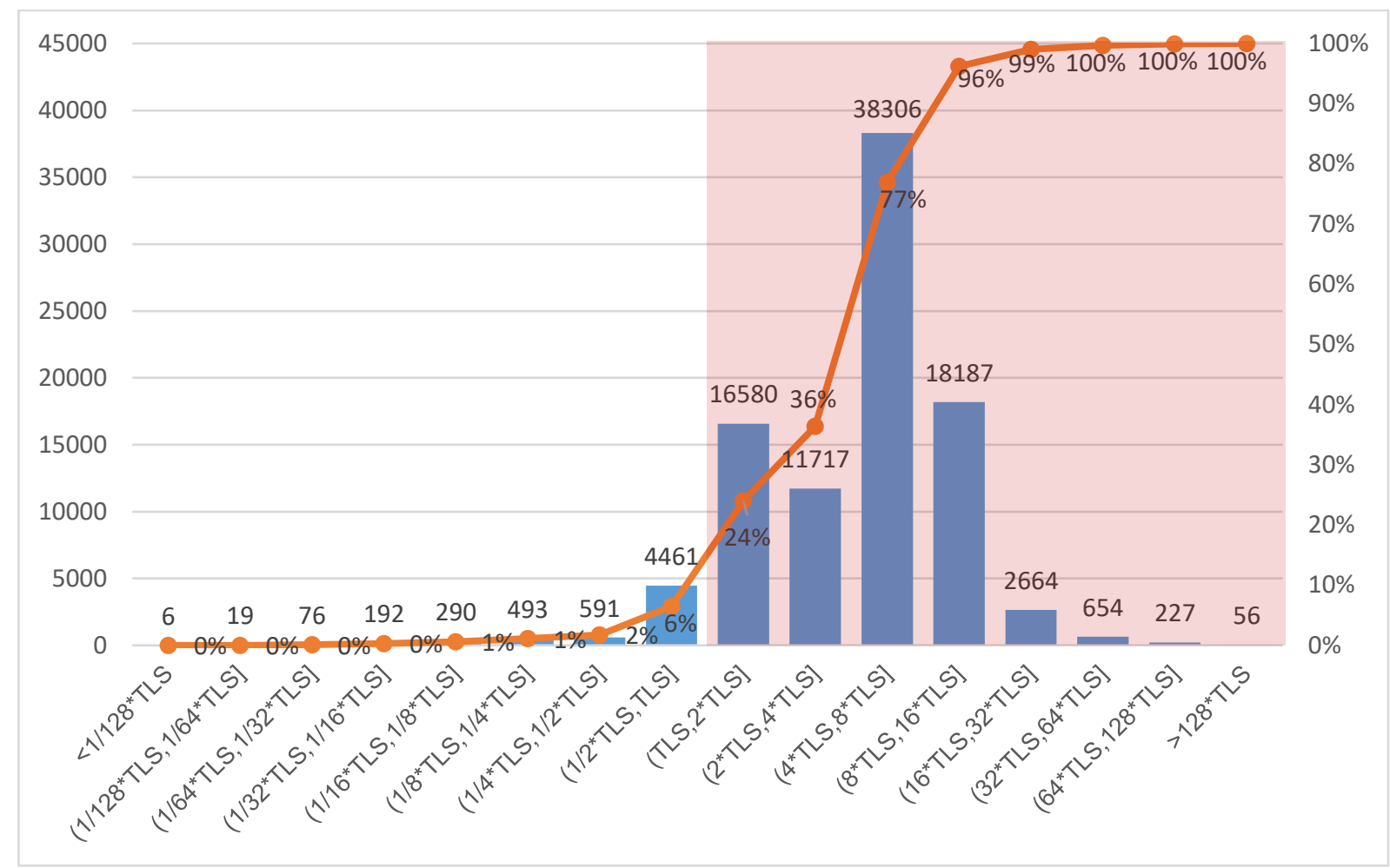

Figura 8 - Distribuição dos riscos das operações de decolagem do Aeroporto de Congonhas

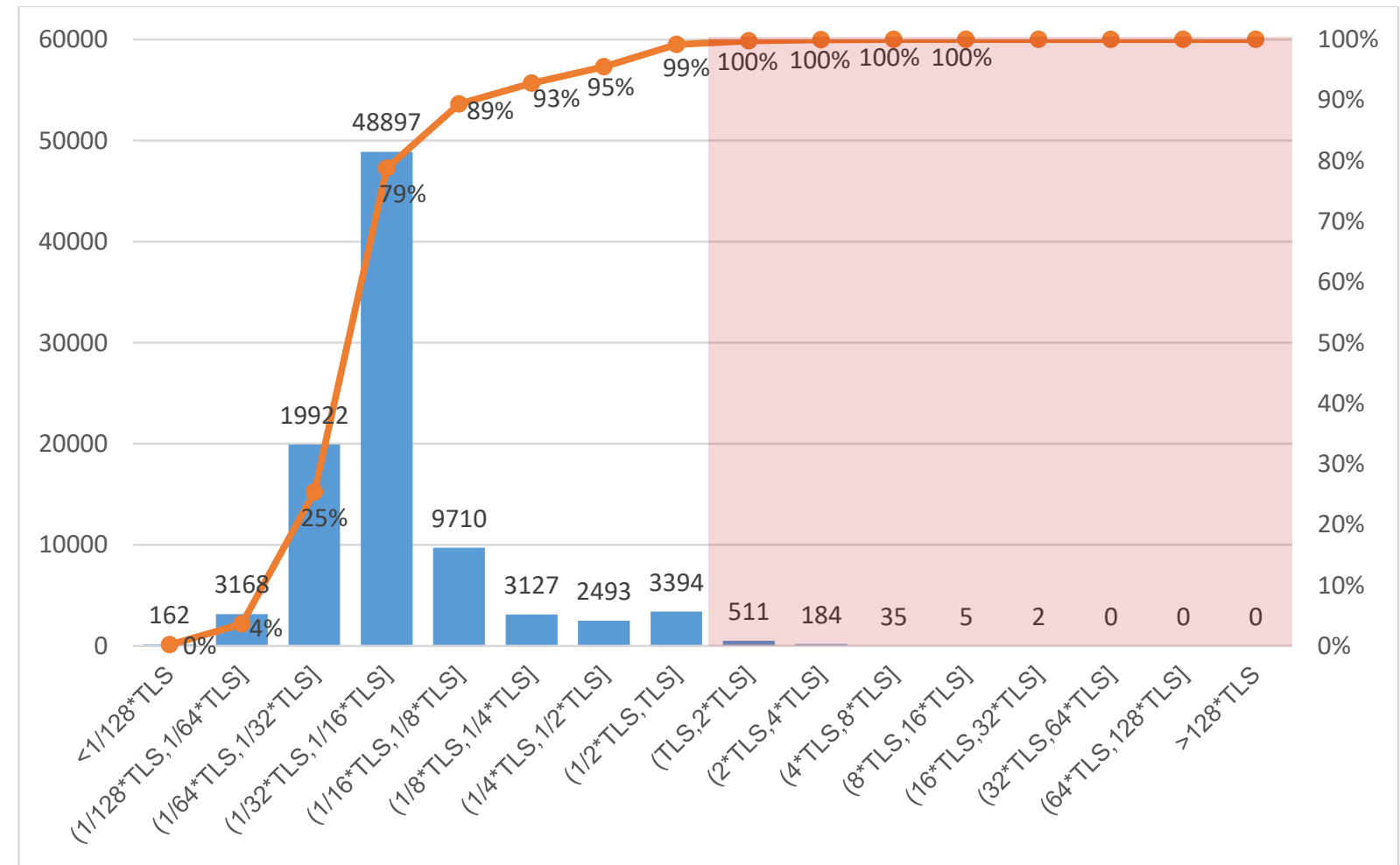

Figura 9 - Distribuição dos riscos das operações de pouso do Aeroporto de Congonhas 
Percebe-se, portanto, que $99 \%$ das operações de pouso e $6 \%$ das operações de decolagem do Aeroporto de Congonhas possuem o risco maior do que $1,0 \times 10^{-7}$.

O tempo esperado para o acidente pode ser determinado ao se supor uma curva de crescimento das operações em termos de movimentações de aeronaves. Como o Aeroporto de Congonhas não possui uma margem considerável para crescimento do número de operações visto que já opera próximo à capacidade, assumiu-se uma curva nula de crescimento das movimentações de aeronaves. O tempo esperado para um acidente no aeroporto de Congonhas é apresentado na Tabela 17.

Tabela 17 - Tempo esperado para um acidente associado à separação entre a pista de pouso e decolagem e as pistas de táxi paralelas no Aeroporto de Congonhas

\begin{tabular}{lccc}
\hline Tempo esperado para o acidente (anos) & 17R & 35L & Total \\
\hline Pouso & 33,3 & 35,4 & 17,2 \\
Decolagem & $>100$ & $>100$ & $>100$ \\
\hline Total & $\mathbf{3 2 , 6}$ & $\mathbf{3 5 , 0}$ & $\mathbf{1 6 , 9}$ \\
\hline
\end{tabular}

Dessa forma, considerando as premissas apresentadas, estimou-se que é esperado um acidente no Aeroporto de Congonhas a cada 16,9 anos devido à excursão lateral ou desvio lateral no pouso.

\subsection{Precificação do evento catastrófico}

Um acidente aeronáutico catastrófico gera uma série de custos diretos e indiretos que devem ser estimados para uma correta Análise de Custo-Benefício. Segundo NLR (2001), dentre os custos diretos, que podem ser reconhecidos como custos seguráveis, destacam-se:

- Dano à Aeronave;

- Mortos e feridos;

- Remoção da aeronave e descontaminação do sítio;

- Danos às cargas e bagagens;

- Custo de atraso e reacomodação dos passageiros

- Perda de investimento em tripulação.

Todavia, existem outros custos indiretos ao acidente que devem ser considerados, como:

- Busca e Salvamento; 
- Custo da Investigação do acidente;

- Perda de reputação;

- Aumento do prêmio de seguros.

\subsubsection{Custos Diretos do Acidente Aeronáutico}

O cálculo do custo direto do acidente aeronáutico catastrófico é feito considerando um modelo específico de aeronave e estimando o custo deste evento com base no valor do equipamento, na quantidade média de pessoas envolvidas, e os demais custos diretos específicos da aeronave em análise. Como as empresas de transporte regular de passageiros que operam em Congonhas utilizam aeronaves com características diferentes, estimou-se o custo do acidente por empresa considerando o modelo da aeronave mais utilizado extraído da base Hotran - Horário de Transporte da ANAC, conforme apresentado na Tabela 18.

Tabela 18 - Aeronave mais utilizada pelas empresas aéreas de transporte regular de passageiros em Congonhas

\begin{tabular}{ccccc}
\hline Empresa & TAM & GOL & Azul & Avianca Brasil \\
\hline Aeronave mais utilizada & A319 & B737-700 & E190 & A319 \\
\hline
\end{tabular}

Cavka e Cokorilo (2012) estimaram o custo de cinco acidentes aeronáuticos catastróficos de uma aeronave Airbus A320-200, equipamento do código de referência 4C, mesmo código das aeronaves consideradas para as quatro companhias aéreas que operam em Congonhas. Dentre os custos diretos do acidente aeronáutico, as componentes de dano à aeronave e de mortos e feridos corresponderam a mais do que $99 \%$ do custo direto total do evento. Para este estudo, os demais custos diretos foram desconsiderados.

Para o cálculo dos custos do dano às aeronaves e de mortos e feridos, utilizou-se as estimativas das consequências dos acidentes por severidade proposta por NLR (2001) apresentada na Tabela 19.

Tabela 19 - Danos às aeronaves e mortes por severidade do acidente aeronáutico

\begin{tabular}{lcc}
\hline Classificação do Acidente (Severidade) & Danos às aeronaves & Mortes \\
\hline Pequeno & $15 \%$ & $0 \%$ \\
Moderado & $50 \%$ & $0 \%$ \\
Grande & $80 \%$ & $0 \%$ \\
Desastre & $100 \%$ & $30 \%$ \\
Catastrófico & $100 \%$ & $80 \%$ \\
\hline
\end{tabular}


Os valores das aeronaves foram calculados através dos preços de tabela dos equipamentos novos apresentados na Tabela 20 e depreciados através da curva proposta por NLR (2001) e apresentada na Tabela 21.

Tabela 20 - Preço das aeronaves novas

\begin{tabular}{cccc}
\hline Aeronave & A319 & B737-700 & E190 \\
\hline Valor (US\$ milhões) & $88,6^{8}$ & $80,6^{9}$ & $49,8^{10}$ \\
\hline
\end{tabular}

Tabela 21 - Curva de depreciação das aeronaves

\begin{tabular}{|c|c|c|c|}
\hline Idade & Valor & Idade & Valor \\
\hline 0 & $100 \%$ & 16 & $39 \%$ \\
\hline 1 & $92 \%$ & 17 & $38 \%$ \\
\hline 2 & $86 \%$ & 18 & $38 \%$ \\
\hline 3 & $81 \%$ & 19 & $37 \%$ \\
\hline 4 & $76 \%$ & 20 & $36 \%$ \\
\hline 5 & $71 \%$ & 21 & $36 \%$ \\
\hline 6 & $66 \%$ & 22 & $32 \%$ \\
\hline 7 & $62 \%$ & 23 & $26 \%$ \\
\hline 8 & $58 \%$ & 24 & $20 \%$ \\
\hline 9 & $54 \%$ & 25 & $15 \%$ \\
\hline 10 & $52 \%$ & 26 & $12 \%$ \\
\hline 11 & $49 \%$ & 27 & $12 \%$ \\
\hline 12 & $46 \%$ & 28 & $14 \%$ \\
\hline 13 & $44 \%$ & 29 & $14 \%$ \\
\hline 14 & $41 \%$ & 30 & $14 \%$ \\
\hline 15 & $40 \%$ & 31 & $13 \%$ \\
\hline
\end{tabular}

Fonte: NLR (2001)

A idade dos equipamentos foi assumida como sendo as idades médias da frota das empresas aéreas apresentada pela Associação Brasileira das Empresas Aéreas - ABEAR (2016) conforme a Tabela 22 .

\footnotetext{
${ }^{8}$ Valor fornecido pela Airbus: < http://www.airbus.com/presscentre/pressreleases/press-releasedetail/detail/new-airbus-aircraft-list-prices-for-2015/>. Acessado em 09/08/2016

${ }^{9}$ Valor fornecido pela Boeing: <http://www.boeing.com/company/about-bca/>. Acessado em 09/08/2016.

${ }^{10}$ Valor informado pela AirInsight < http://airinsight.com/2016/05/16/aircraft-pricing-list-vs-market/>. Acessado em 09/08/2016.
} 
Tabela 22 - Idade média da frota das aeronaves das empresas de transporte regular de passageiros

\begin{tabular}{lcc}
\hline Empresa & Idade Média & Quantidade \\
\hline TAM & 7,1 anos & 129 \\
GOL & 7,0 anos & 137 \\
AVIANCA BRASIL & 9,4 anos & 38 \\
AZUL & 2,7 anos & 74 \\
\hline ABEAR & 6,4 anos & 378 \\
\hline
\end{tabular}

Fonte: ABEAR (2016)

Para o custo dos feridos, utilizou-se as estimativas de consequências do acidente catastrófico constantes da Tabela 19. Assim, assumiu-se que $80 \%$ das pessoas presentes no avião somando os passageiros e a tripulação morreriam, e os restantes ficariam feridos.

Foi utilizado o Valor Estatístico da Vida (VSL, Value of Statistical Life) calculado no Capítulo 2 de 5,1 milhões de reais, bem como os valores de 4,1 e 8,0 sugeridos para as análises de sensibilidade. Considerou-se também a estimativa NLR (2001) do Valor dos Ferimentos (VSI, Value of Statistical Injury) como 13\% do VSL.

O número de assentos das aeronaves consideradas foi extraído da base Hotran - Horário de Transporte da ANAC. Assumiu-se como o fator de ocupação das aeronaves (load factor) o fator médio da aviação civil brasileira divulgado no Anuário do Transporte Aérea da ANAC (2014) de 79,9\%.

Por fim, o custo direto do acidente aeronáutico foi calculado através da média ponderada dos custos do acidente das empresas aéreas considerando como pesos as fatias de mercado das empresas em Congonhas calculados através dos dados do BINTRA, apresentados na Tabela 23.

Tabela 23 - Fatias de Mercado das empresas de transporte regular de passageiros no Aeroporto de Congonhas

\begin{tabular}{lcc}
\hline Empresa & Número de Operações & Percentual \\
\hline TAM & 8759 & $43,7 \%$ \\
GOL & 74435 & $43,0 \%$ \\
AZUL & 75562 & $5,1 \%$ \\
AVIANCA BRASIL & 14184 & $8,2 \%$ \\
\hline Total & 172940 & \\
\hline
\end{tabular}

O custo direto do acidente catastrófico esperado para o Aeroporto de Congonhas foi de 665,0 milhões de reais. O detalhamento do cálculo do custo pode ser observado na Tabela 24. 
Tabela 24 - Custo Direto do acidente aeronáutico catastrófico no Aeroporto de Congonhas

\begin{tabular}{|c|c|c|c|c|}
\hline Empresa & TAM & GOL & Azul & Avianca \\
\hline Aeronave mais utilizada & A319 & B737-700 & E190 & A319 \\
\hline Valor do Equipamento novo (US\$ milhões) & 88,6 & 80,6 & 49,8 & 88,6 \\
\hline Cotação Dólar (31/12/2015) & \multicolumn{4}{|c|}{3,331} \\
\hline Valor do equipamento novo ( $\mathrm{R} \$$ milhões) & 295,1 & 268,5 & 165,9 & 295,1 \\
\hline Idade média considerada (anos) & 7 & 7 & 3 & 9 \\
\hline Valor com depreciação (\%) & $62 \%$ & $62 \%$ & $81 \%$ & $54 \%$ \\
\hline Custo de Danos às Aeronaves ( $\mathrm{R} \$$ milhões) & 183,0 & 166,5 & 134,4 & 159,4 \\
\hline Capacidade Máxima de Passageiros & 144 & 138 & 118 & 132 \\
\hline Load Factor & \multicolumn{4}{|c|}{$79,9 \%$} \\
\hline Passageiros & 115 & 110 & 94 & 105 \\
\hline Tripulação & 6 & 6 & 6 & 6 \\
\hline Mortos (percentual) & \multicolumn{4}{|c|}{$80 \%$} \\
\hline Mortos & 97 & 93 & 80 & 89 \\
\hline Feridos & 24 & 23 & 20 & 22 \\
\hline VSL (R\$ milhões) & \multicolumn{4}{|c|}{5,1} \\
\hline Custo de Mortes [VSL x Mortos] & 494,7 & 474,3 & 408,0 & 453,9 \\
\hline VOI [\% VSL] & \multicolumn{4}{|c|}{$13 \%$} \\
\hline VOI (R \$ milhões) & \multicolumn{4}{|c|}{0,663} \\
\hline Custo dos Feridos & 15,9 & 15,2 & 13,3 & 14,6 \\
\hline Custo de Mortos e Feridos ( $\mathrm{R} \$$ milhões) & 511 & 490 & 421 & 468 \\
\hline Custos Diretos do Acidente (R\$ milhões) & 693,6 & 656,0 & 555,6 & 627,9 \\
\hline Fatia de Mercado em Congonhas & $43,7 \%$ & $43,0 \%$ & $5,1 \%$ & $8,2 \%$ \\
\hline Custos Diretos do Acidente (R\$ milhões) & \multicolumn{4}{|c|}{665,0} \\
\hline
\end{tabular}

\subsubsection{Custos Indiretos do Acidente Aeronáutico}

Os custos indiretos são difíceis de se mensurar e nesta análise de caso utilizou-se a estimativa de Cavka e Cokorilo (2012) de que os custos indiretos de um acidente catastrófico ficam no intervalo de $90 \%$ a $140 \%$ dos custos diretos desse acidente. Para isso, foi assumido o valor médio do intervalo, ou seja, $115 \%$, e foi feita uma análise de sensibilidade desse valor ao final considerando os limites superior e inferior deste intervalo.

Todavia, como a ordem de grandeza e a incerteza dos custos indiretos são grandes, realizou-se adicionalmente uma Análise de Custo-Benefício Parcial, conforme preconizado no Capítulo 2, onde não foi considerado nenhum custo indireto do acidente aeronáutico. 


\subsubsection{Custos Total do Acidente Aeronáutico}

Obteve-se, portanto, o Custo Total esperado para um acidente aeronáutico catastrófico no Aeroporto de Congonhas como 1429,8 milhões de reais através do Custo Direto esperado para o acidente e do intervalo do Custo Indireto A Tabela 25 apresenta 9 cenários de custos totais para análise de sensibilidade da $\mathrm{ACB}$, bem como 3 cenários para a $\mathrm{ACB}$ Parcial que desconsidera os Custos Indiretos do acidente aeronáutico.

Tabela 25 - Custo esperado para um acidente aeronáutico catastrófico em Congonhas

\begin{tabular}{ccccc}
\hline \multirow{2}{*}{$\begin{array}{c}\text { Custo Total do Acidente Aeronáutico } \\
\text { (R\$ milhões) }\end{array}$} & \multicolumn{3}{c}{$\begin{array}{c}\text { Value of Statistical Life (VSL) } \\
\text { (R\$ milhões) }\end{array}$} \\
\cline { 3 - 5 } & $\mathbf{9 0 \%}$ & 1061,2 & 1263,5 & $\mathbf{8 , 0}$ \\
\hline & $\mathbf{4 , 1}$ & $\mathbf{5 , 1}$ & 1796,7 \\
$\begin{array}{c}\text { Custo Indireto } \\
\text { (\% Custo Direto) }\end{array}$ & $\mathbf{1 1 5 \%}$ & 1200,9 & $\mathbf{1 4 2 9 , 8}$ & 2033,1 \\
& $\mathbf{1 4 0 \%}$ & 1340,5 & 1596,0 & 2269,5 \\
\hline $\begin{array}{c}\text { Sem Custos Indiretos } \\
\text { (Análise de Custo-Benefício Parcial) }\end{array}$ & 558,6 & $\mathbf{6 6 5 , 0}$ & 945,6 \\
\hline
\end{tabular}

\subsection{Estimativa do custo para adequação do aeroporto aos requisitos de projeto}

Foi escolhida como alternativa ao cenário atual para a Análise de Custo-Benefício a construção da Pista de Pouso e Decolagem Central proposta por Rabbani e Moser (2010) de mesma dimensão da PPD 17R/35L (Pista Principal), conforme a Figura 10.

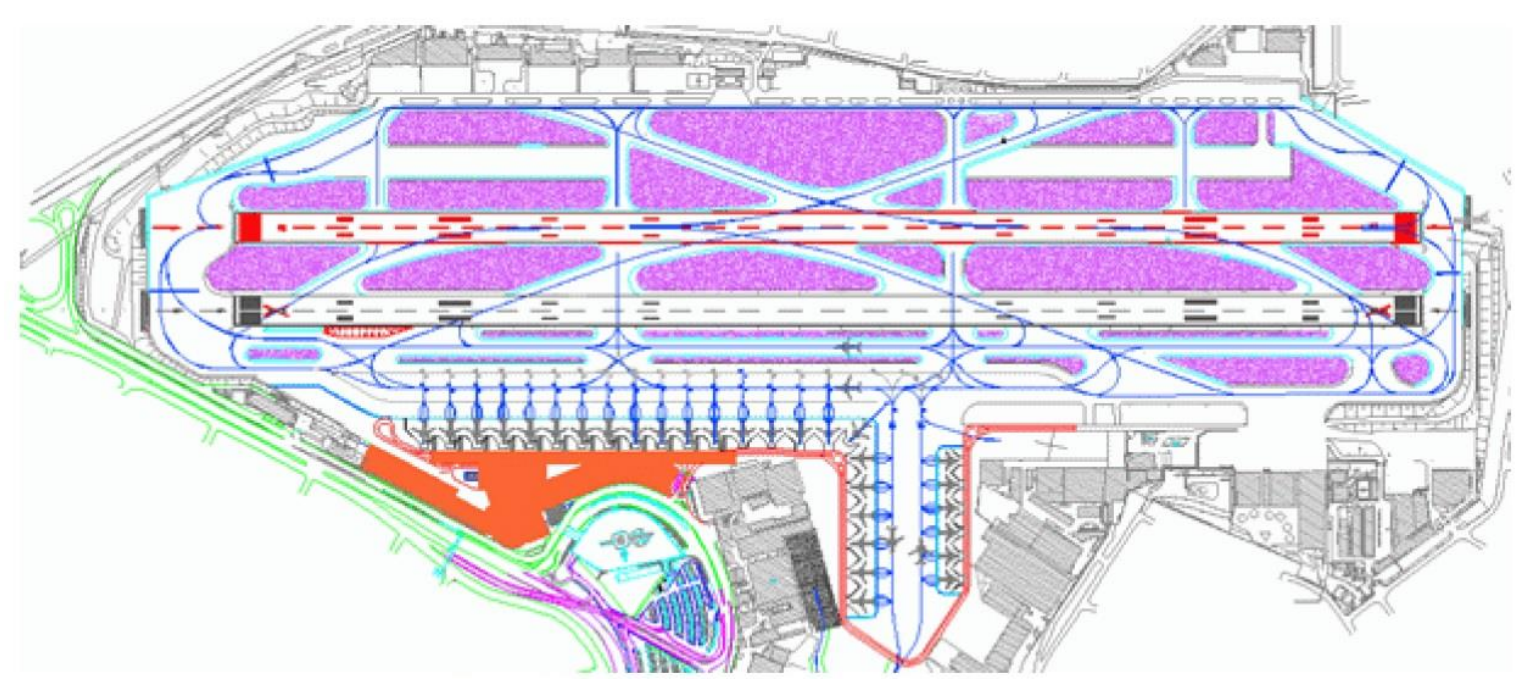

Fonte: Rabbani e Moser (2010)

Figura 10 - Pista de Pouso e Decolagem Central proposta para o Aeroporto de Congonhas 
A estimativa de custo de obra se dá após a elaboração de seu projeto ou de um prédimensionamento, e para isso seriam necessários diversos estudos de engenharia, incluindo estudos geotécnicos de sondagem do solo que extrapolam o escopo deste trabalho.

Como alternativa, buscou-se os estudos mais recentes de custos de novas pistas de pouso e decolagem dos aeroportos brasileiros, dentre os quais destacam-se os Estudos Preliminares de Engenharia constantes dos EVTEA (Estudo de Viabilidade Técnica, Econômica e Ambiental) elaborados para as concessões aeroportuárias.

Existem seis aeroportos concedidos e quatro em fase de concessão com os EVTEA já elaborados. Desses dez estudos, quatro preveem a construção de novas pistas de pouso e decolagem, quais sejam, Aeroporto de Campinas (SBKP), Aeroporto de Confins (SBCF), Aeroporto de Galeão (SBGL) e Aeroporto de Salvador (SBSV).

Foi levantado nos EVTEA o custo total previsto para a construção dessas pistas de pouso e decolagem, incluindo o custo do sistema de pistas de táxis. Esses valores foram convertidos a valor presente utilizando o INCC (Índice Nacional da Construção Civil). Calculou-se o valor médio dos investimentos a valor presente dividido pela área prevista para essas pistas. Por fim, foi calculado o custo médio de investimentos dos sistemas de pista por metro quadrado de pavimento de pista de pouso e decolagem. Esses dados são apresentados na Tabela 26.

Tabela 26 - Custo dos sistemas de pista estimados para as Concessões Aeroportuárias

\begin{tabular}{|c|c|c|c|c|c|c|c|}
\hline Aeroporto & PPD & $\begin{array}{l}\text { Dimensões } \\
(\mathbf{m})\end{array}$ & Ano & $\begin{array}{l}\text { Valor Total } \\
\text { (R\$ milhões) }\end{array}$ & $\begin{array}{c}\text { Valor Presente } \\
\text { (R\$ milhões) }\end{array}$ & $\begin{array}{l}\text { Área de } \\
\operatorname{PPD}\left(\mathrm{m}^{2}\right)\end{array}$ & $\begin{array}{c}\text { Valor } \\
\text { Presente/m }\end{array}$ \\
\hline SBKP & $2^{a}$ & $3600 \times 60$ & 2011 & 223,94 & 320,37 & 216.000 & $\mathrm{R} \$ 1.483,20$ \\
\hline SBKP & $3^{a}$ & $2600 \times 45$ & 2011 & 85,47 & 122,27 & 117.000 & $\mathrm{R} \$ 1.045,08$ \\
\hline SBKP & $4^{a}$ & $2200 \times 45$ & 2011 & 72,29 & 103,42 & 99.000 & $\mathrm{R} \$ 1.044,63$ \\
\hline SBCF & $2^{a}$ & $2500 \times 45$ & 2013 & 163,04 & 202,57 & 112.500 & $\mathrm{R} \$ 1.800,63$ \\
\hline SBGL & $2^{a}$ & $3000 \times 60$ & 2013 & 300,69 & 373,60 & 180.000 & $\mathrm{R} \$ 2.075,54$ \\
\hline SBGL & $3^{\mathrm{a}}$ & $3700 \times 60$ & 2013 & 423,53 & 526,22 & 222.000 & $\mathrm{R} \$ 2.370,36$ \\
\hline SBSV & $3^{a}$ & $2400 \times 45$ & 2015 & 149,11 & 160,27 & 108.000 & $\mathrm{R} \$ 1.483,99$ \\
\hline
\end{tabular}

Custo médio dos sistemas de pista por $\mathrm{m}^{2}$ de pavimento de pista de pouso e decolagem $\mathrm{R} \$ 1.614,78$ 
Os custos médios encontrados para a construção das pistas de pouso e decolagem e sistemas de pistas de táxi adjacentes foi de $\mathrm{R} \$ 1.614,78$ por metro quadrado de pista de pouso e decolagem construída.

Assim, o custo da construção da pista de pouso e decolagem central, com as dimensões iguais à PPD 17R/35L, 1940 x 45 metros, foi estimado em 141,0 milhões de reais.

Cabe ressaltar que os estudos preliminares de engenharia dos EVTEA avaliados previram obras bastante desafiadoras, com grandes serviços de terraplenagem como o caso do Aeroporto de Confins e até mesmo o aterramento da Baia de Guanabara para o Aeroporto de Galeão. Todavia, a construção de uma nova pista de pouso e decolagem entre as duas pistas existentes do aeroporto de Congonhas também possui a sua complexidade logística e de engenharia, principalmente para manutenção das operações durante a sua construção.

\subsection{Quantificação do risco operacional com a adequação da infraestrutura aos requisitos de projeto}

Para o cálculo do risco operacional do cenário de adequação da Infraestrutura aos requisitos de projetos contidos no RBAC 154, ou seja, uma configuração da área de movimento do aeroporto com a separação entre a Pista de Pouso e Decolagem e as pistas de táxi paralelas de 168 metros, repetiu-se os procedimentos contidos na seção 4.2. Os valores do risco total associado à separação das pistas de táxi paralelas estimados para o cenário da adequação do Aeroporto de Congonhas podem ser observados na Tabela 27.

Tabela 27 - Probabilidade de acidente no Aeroporto de Congonhas associada à separação das Pistas de Táxi paralelas com a adequação da infraestrutura

\begin{tabular}{lccc}
\hline Probabilidade do Acidente & $\mathbf{1 7 R}$ & 35L & Total \\
\hline Pouso & $1,616 \mathrm{E}-07$ & $1,996 \mathrm{E}-07$ & $1,780 \mathrm{E}-07$ \\
Decolagem & $3,666 \mathrm{E}-09$ & $2,200 \mathrm{E}-09$ & $3,014 \mathrm{E}-09$ \\
\hline Total & $\mathbf{8 , 4 7 8 E - 0 8}$ & $\mathbf{1 , 0 1 0 E - 0 7}$ & $\mathbf{9 , 1 8 8 E - 0 8}$ \\
\hline
\end{tabular}

Percebe-se então que o risco médio das operações de pouso é $1,780 \times 10^{-7}$ e o risco médio

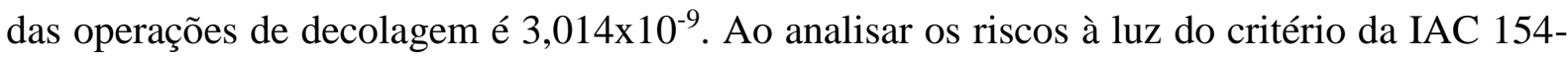
1001, percebe-se que a operação de pouso no Aeroporto de Congonhas, mesmo com a infraestrutura atendendo os requisitos de projeto, ainda possui risco superior a $1,0 \times 10^{-7}$ (TLS). Todavia, o risco médio das operações de pouso e decolagem é $9,188 \times 10^{-8}$, sendo $8,12 \%$ inferior ao TLS. 
O tempo esperado para o acidente, supondo também que não haja aumento do número de operações de pouso de decolagem, é apresentado na Tabela 28.

Tabela 28 - Tempo esperado para um acidente associado à separação entre a pista de pouso e decolagem e as pistas de táxi paralelas em Congonhas com a adequação da infraestrutura

\begin{tabular}{lccc}
\hline Tempo esperado para o acidente (anos) & $\mathbf{1 7 R}$ & $\mathbf{3 5 L}$ & Total \\
\hline Pouso & 115,2 & 122,8 & 59,4 \\
Decolagem & $>1000$ & $>1000$ & $>1000$ \\
\hline Total & $\mathbf{1 1 2 , 8}$ & $\mathbf{1 2 1 , 5}$ & $\mathbf{5 8 , 5}$ \\
\hline
\end{tabular}

Dessa forma, considerando as premissas apresentadas, estimou-se que seria esperado um acidente no Aeroporto de Congonhas a cada 58,5 anos devido à excursão lateral ou desvio lateral no pouso caso a infraestrutura estivesse em conformidade aos requisitos de projeto.

\subsection{Análise de custo-benefício da adequação da infraestrutura}

Após a conclusão dos estudos realizados em 4.2 a 4.5 foi possível a realização da Análise de Custo-Benefício através do estabelecimento de algumas premissas, quais sejam:

1. A construção da Pista de Pouso e Decolagem Central será executada em dois anos com valor de 141,0 milhões de reais despendidos a metade no primeiro ano e o restante no segundo.

2. Durante a adequação da infraestrutura, a execução da obra constitui um novo obstáculo à Faixa de Pista, aumentando o risco de acidentes durante os dois anos de construção da pista.

3. Considerou-se um período de 50 anos para a análise de custo-benefício.

4. Assumiu-se uma curva nula de crescimento das operações de pouso e decolagem no Aeroporto de Congonhas.

A premissa número 2 é conservadora no que tange à análise de custo-benefício, já que se assumiu que obra aconteceria concomitantemente com as operações sem nenhuma mitigação, aumentando, portanto, o risco de acidentes nos dois anos de sua execução. Todavia, um correto planejamento da obra localizada próxima a uma pista de pouso e decolagem deve ser feito embasado em uma análise de risco e estabelecimento de procedimentos operacionais que mitiguem o risco adicional resultante da obra.

Porém, essa premissa se fez necessária visto que essas ações mitigadoras podem, porventura, encarecer a obra ou até mesmo apresentar alguma restrição operacional ao 
aeroporto durante a sua execução, que podem aumentar o fechamento do aeroporto em condições meteorológicas desfavoráveis, o que não foi quantificado na análise de custobenefício por ser complexo de se estimar corretamente antes da elaboração do projeto e do planejamento de sua execução.

Ressalta-se que a proposta de Rabbani e Moser (2010) mostra que a separação entre a PPD 17R/35L e a obra seria maior do que a separação entre esta pista e a ponta das asas das aeronaves código C que utilizam as Pistas de Táxi E e M. Estima-se que essa separação seria de aproximadamente 100 metros.

O risco das operações de pouso e decolagem durante a obra foi calculado utilizando novamente os procedimentos contidos na seção 4.2. Os valores estimados para os riscos podem ser observados na Tabela 29.

Tabela 29 - Probabilidade de acidente durante a fase de obras no Aeroporto de Congonhas associado à separação das Pistas de Táxi paralelas

\begin{tabular}{lccc}
\hline Probabilidade do Acidente & 17R & 35L & Total \\
\hline Pouso & $7,154 \mathrm{E}-07$ & $8,854 \mathrm{E}-07$ & $7,887 \mathrm{E}-07$ \\
Decolagem & $1,497 \mathrm{E}-08$ & $8,969 \mathrm{E}-09$ & $1,230 \mathrm{E}-08$ \\
\hline Total & $\mathbf{3 , 7 4 7 E - 0 7}$ & $\mathbf{4 , 4 7 6 E - 0 7}$ & $\mathbf{4 , 0 6 6 E - 0 7}$ \\
\hline
\end{tabular}

Rabbani e Moser (2010) mostraram que, apesar da proposta de adequação da infraestrutura possuir apenas uma pista de pouso e decolagem central, em contrapartida das duas pistas que o aeroporto hoje possui, é esperado um aumento da capacidade operacional e uma redução dos atrasos mesmo com a pista única em decorrência do ganho operacional que as pistas de táxi de saídas rápidas propiciaram ao Aeroporto de Congonhas. Esses benefícios não foram quantificados nessa análise de custo-benefício.

\subsubsection{Análise de Custo-Benefício}

Para a Análise de Custo-Benefício foi elaborado o fluxo de caixa marginal apresentado no Apêndice B considerando os resultados dos estudos 4.2 a 4.5 e as premissas retromencionadas. Após a elaboração do fluxo de caixa marginal, calculou-se o NPV, a Relação Benefício-Custo (B/C) e a Taxa Interna de Retorno (TIR) através das equações (23), (24) e (25).

$$
V P L=\sum_{i=0}^{k} \frac{\left(B_{i}-C_{i}\right)}{(1+r)^{i}}
$$




$$
\begin{gathered}
B / C=\frac{\sum_{i=0}^{k} \frac{B_{i}}{(1+r)^{i}}}{\sum_{i=0}^{k} \frac{C_{i}}{(1+r)^{i}}} \\
T I R=(r \mid V P L=0)
\end{gathered}
$$

A Taxa de Desconto $(r)$ utilizada foi a taxa SELIC de 2015 descontada da Inflação do mesmo ano.

$$
r=\frac{(100+14,15)}{(100+8,85)}=4,87 \%
$$

Foi realizada uma análise de sensibilidade com a Taxa de Desconto de $7 \%$.

O resultado da Análise de Custo-Benefício encontrado foi que os benefícios da adequação da infraestrutura com a construção da Pista de Pouso e Decolagem Central superam os custos em 871,7 milhões de reais. A Relação de Benefício-Custo da adequação proposta foi de 5,7 e o tempo de payback ${ }^{11}$ foi de 5 anos e 7 meses. A Taxa Interna de Retorno obtida foi $28,0 \%$, ou seja, mesmo ao custo de capital real de $28,0 \%$ ainda seria economicamente vantajosa a adequação da infraestrutura pela solução em análise. A comparação entre os custos esperados para o cenário atual (status quo) e para o cenário da adequação da infraestrutura é apresentada na Figura 11.

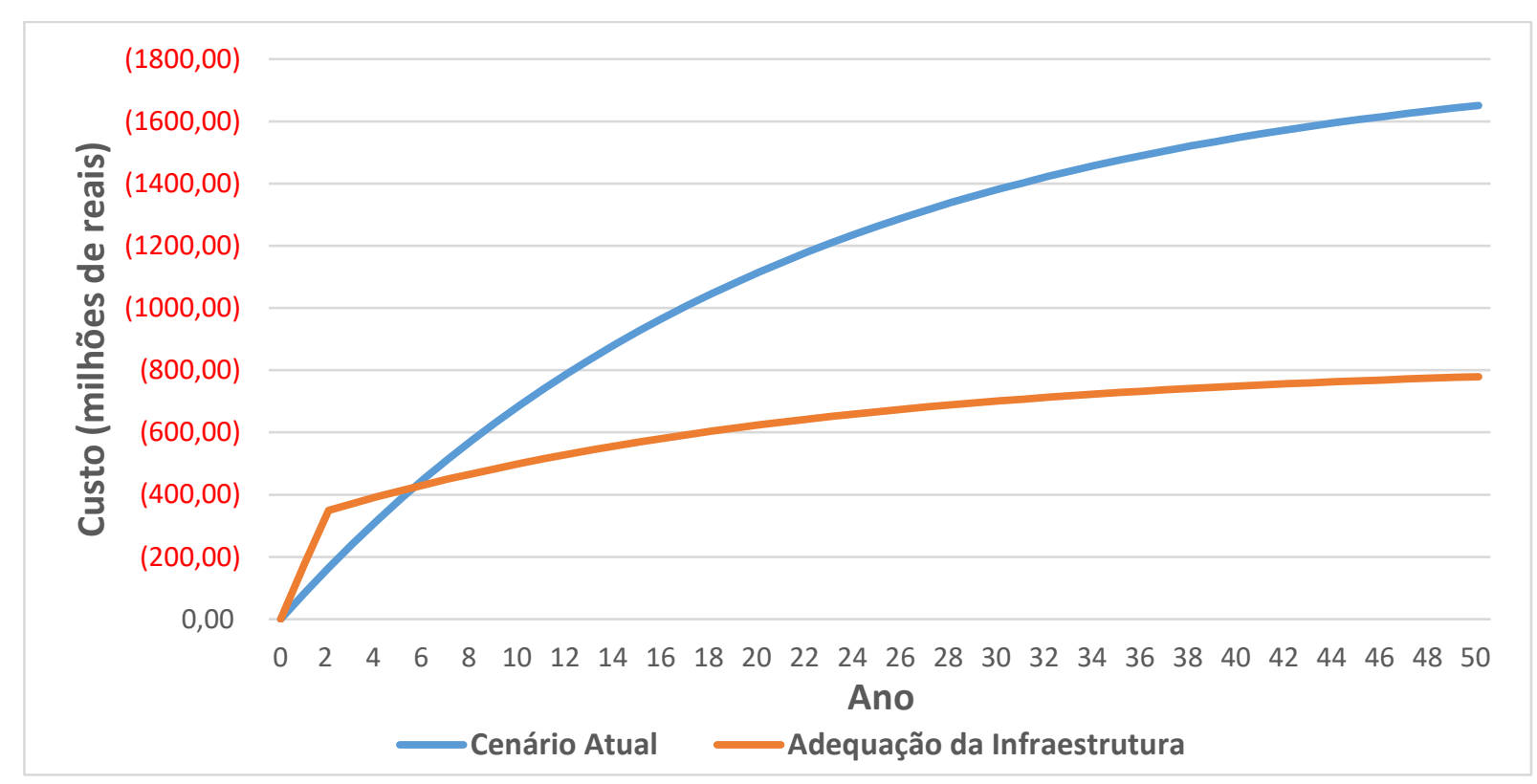

Figura 11 - Custos esperados Cenário Atual e Cenário Adequação da Infraestrutura

\footnotetext{
${ }^{11}$ Não se trata de um payback financeiro (convencional), mas sim de payback regulatório (de bem-estar social).
} 
O fluxo de caixa descontado e o fluxo de caixa descontado acumulado obtido na ACB da adequação da infraestrutura em contrapartida ao cenário atual (status quo) são apresentados respectivamente na Figura 12 e Figura 13.

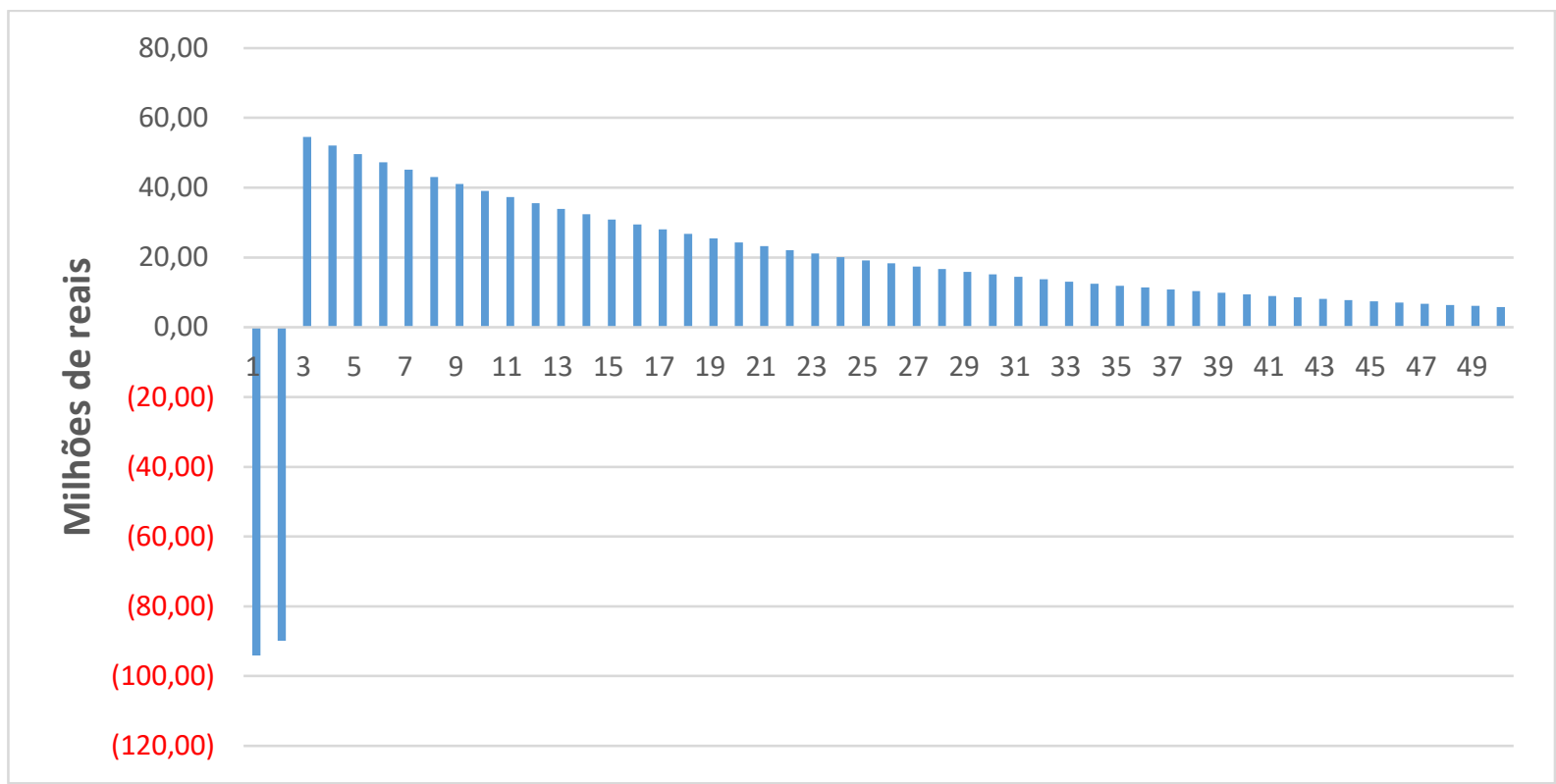

Figura 12 - Fluxo de Caixa descontado da adequação da infraestrutura em contrapartida ao cenário atual

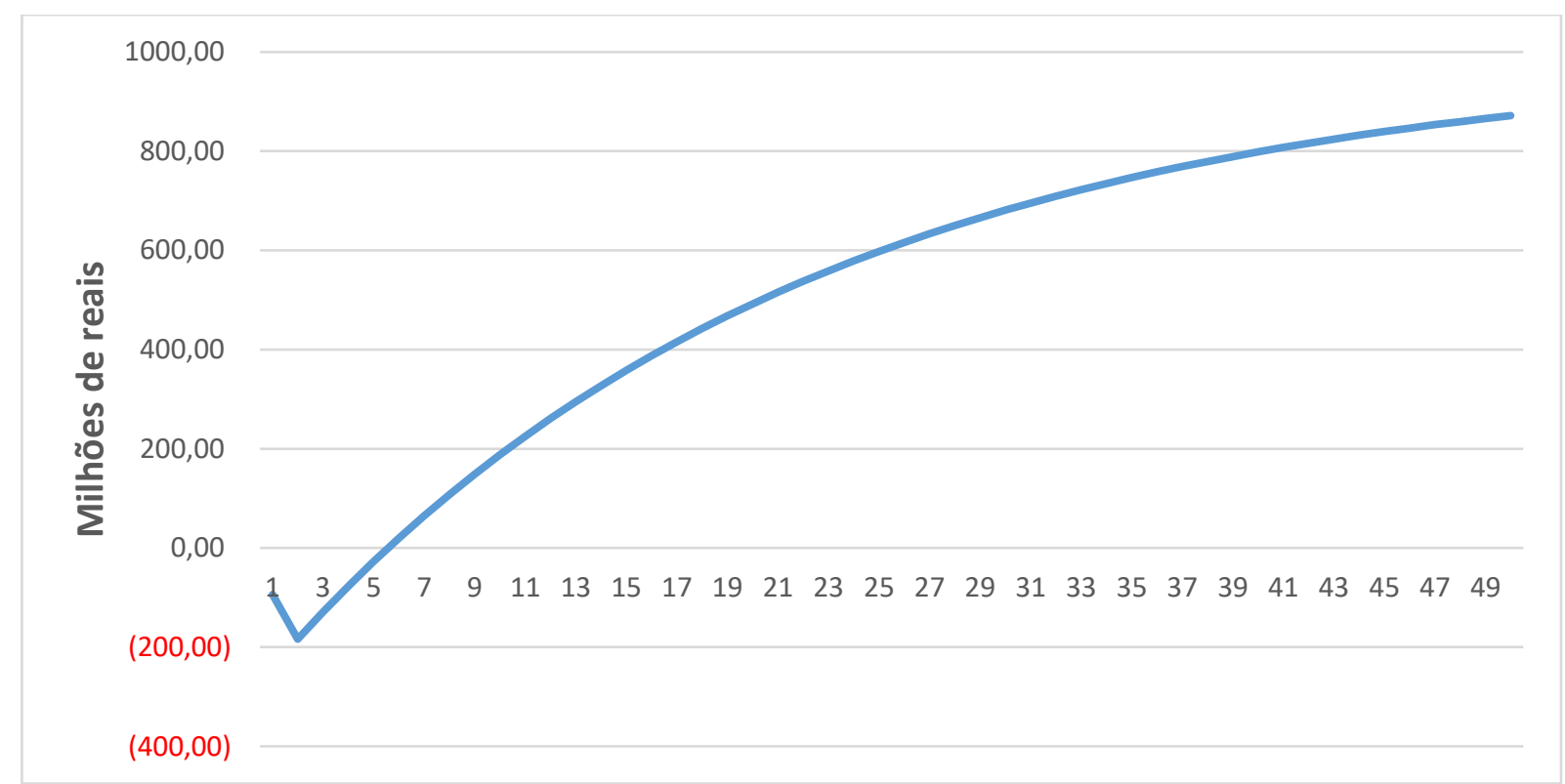

Figura 13 - Fluxo de Caixa descontado acumulado da adequação da infraestrutura em contrapartida ao cenário atual

Foram realizadas as análises de sensibilidade em função do Custo Total do Acidente proposta em 4.3 e em função das Taxas de Desconto propostas. Os resultados estão apresentados no Quadro 3. 
Quadro 3 - Análise de Sensibilidade da ACB

\begin{tabular}{|c|c|c|c|c|c|c|c|c|c|c|c|}
\hline \multirow{2}{*}{\multicolumn{3}{|c|}{$\begin{array}{c}\text { Análise de Sensibilidade } \\
\begin{array}{c}\text { VSL } \\
\text { (milhões R\$) }\end{array}\end{array}$}} & \multicolumn{9}{|c|}{ Cenários } \\
\hline & & & \multicolumn{3}{|c|}{4,1} & \multicolumn{3}{|c|}{5,1} & \multicolumn{3}{|c|}{8,0} \\
\hline \multicolumn{3}{|c|}{$\begin{array}{l}\text { Custo Direto do Acidente } \\
\text { (milhões R\$) }\end{array}$} & \multicolumn{3}{|c|}{558,6} & \multicolumn{3}{|c|}{665,0} & \multicolumn{3}{|c|}{945,6} \\
\hline \multicolumn{3}{|c|}{$\begin{array}{l}\text { Custo Indireto Acidente } \\
\text { (\% Custo Direto) }\end{array}$} & $90 \%$ & $115 \%$ & $140 \%$ & $90 \%$ & $115 \%$ & $140 \%$ & $90 \%$ & $115 \%$ & $140 \%$ \\
\hline \multicolumn{3}{|c|}{$\begin{array}{l}\text { Custo Total Acidente } \\
\text { (milhões R\$) }\end{array}$} & 1061,2 & 1200,9 & 1340,5 & 1263,5 & 1429,8 & 1596,0 & 1796,7 & 2033,1 & 2269,5 \\
\hline \multirow{6}{*}{ 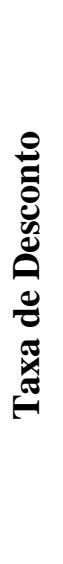 } & \multirow{3}{*}{$4,87 \%$} & VPL (milhões R\$) & 611,5 & 710,1 & 808,7 & 754,3 & 871,7 & 989,1 & 1130,8 & 1297,7 & 1464,6 \\
\hline & & Relação Benefício-Custo & 4,6 & 5,0 & 5,5 & 5,2 & 5,7 & 6,2 & 6,8 & 7,4 & 7,9 \\
\hline & & Payback & $\begin{array}{l}6 \text { anos e } \\
7 \text { meses }\end{array}$ & $\begin{array}{l}6 \text { anos e } \\
2 \text { meses }\end{array}$ & $\begin{array}{l}5 \text { anos e } \\
9 \text { meses }\end{array}$ & 6 anos & $\begin{array}{l}5 \text { anos e } \\
7 \text { meses }\end{array}$ & $\begin{array}{l}5 \text { anos e } \\
3 \text { meses }\end{array}$ & 5 anos & $\begin{array}{l}4 \text { anos e } \\
9 \text { meses }\end{array}$ & $\begin{array}{l}4 \text { anos e } \\
6 \text { meses }\end{array}$ \\
\hline & \multirow{3}{*}{$7 \%$} & VPL (milhões R\$) & 401,4 & 472,2 & 543,0 & 503,9 & 588,2 & 672,4 & 774,2 & 894,0 & 1013,8 \\
\hline & & Relação Benefício-Custo & 3,4 & 3,7 & 4,0 & 3,8 & 4,2 & 4,6 & 5,0 & 5,4 & 5,8 \\
\hline & & Payback & 7 anos & $\begin{array}{l}6 \text { anos e } \\
5 \text { meses }\end{array}$ & 6 anos & $\begin{array}{l}6 \text { anos e } \\
3 \text { meses }\end{array}$ & $\begin{array}{l}5 \text { anos e } \\
10 \text { meses }\end{array}$ & $\begin{array}{l}5 \text { anos e } \\
6 \text { meses }\end{array}$ & $\begin{array}{l}5 \text { anos e } \\
2 \text { meses }\end{array}$ & $\begin{array}{l}4 \text { anos e } \\
11 \text { meses }\end{array}$ & $\begin{array}{l}4 \text { anos e } \\
8 \text { meses }\end{array}$ \\
\hline \multicolumn{3}{|r|}{ TIR } & $22,7 \%$ & $24,8 \%$ & $26,8 \%$ & $25,7 \%$ & $28,0 \%$ & $30,0 \%$ & $32,4 \%$ & $34,9 \%$ & $37,2 \%$ \\
\hline
\end{tabular}


Todos os 18 cenários avaliados ( 9 custos totais do acidente e 2 taxas de desconto) indicaram que os benefícios da adequação superam os custos. A Relação Benefício-Custo calculada para todos os cenários variou de 3,4 a 7,9 e o payback time entre 4 anos e 6 meses no mais otimista e 7 anos no mais pessimista. Percebe-se, portanto, que em qualquer um dos cenários avaliados a adequação da infraestrutura pela solução proposta é economicamente vantajosa, visto que os custos estimados para os riscos superam, em muito, os investimentos estimados para a adequação da infraestrutura.

Calculou-se que mesmo se fossem gastos 1 bilhão de reais na Pista de Pouso e Decolagem Central do Aeroporto de Congonhas (600\% a mais do que o estimado) apenas visando a redução do risco às operações, ainda assim seria uma solução vantajosa do ponto de vista do bem-estar social mesmo desconsiderando todos os benefícios adicionais consequente da adequação do aeroporto.

\subsubsection{Análise de Custo-Benefício Parcial}

Considerando que existe uma grande incerteza quando ao Custo Indireto do acidente aeronáutico, dada a sua dificuldade de cálculo e variabilidade, foi proposta na seção 4.3 deste trabalho a realização de uma Análise de Custo-Benefício Parcial. Segundo a literatura e conforme discutido no Capítulo 2, quando não é possível a estimação de todos os benefícios e custos, uma ACB Parcial pode ser realizada e ainda ser de grande valia para o processo de tomada de decisão, visto que reduz a extensão das análises qualitativas e, portanto, mais subjetivas, que venham a ser necessárias para a conclusão da análise.

O resultado a Análise de Custo-Benefício Parcial foi que os benefícios da adequação da infraestrutura com a construção da Pista de Pouso e Decolagem Central superam os custos diretos em 331,8 milhões de reais. A Relação Benefício-Custo da adequação proposta foi de 3,1, o tempo de payback foi de 9 anos e 3 meses e a IRR obtida foi 15,9\%. A comparação entre o custo total, incluindo o custo esperado e o custo do investimento, para o cenário atual (status quo) e o cenário da adequação da infraestrutura é apresentada na Figura 14. 


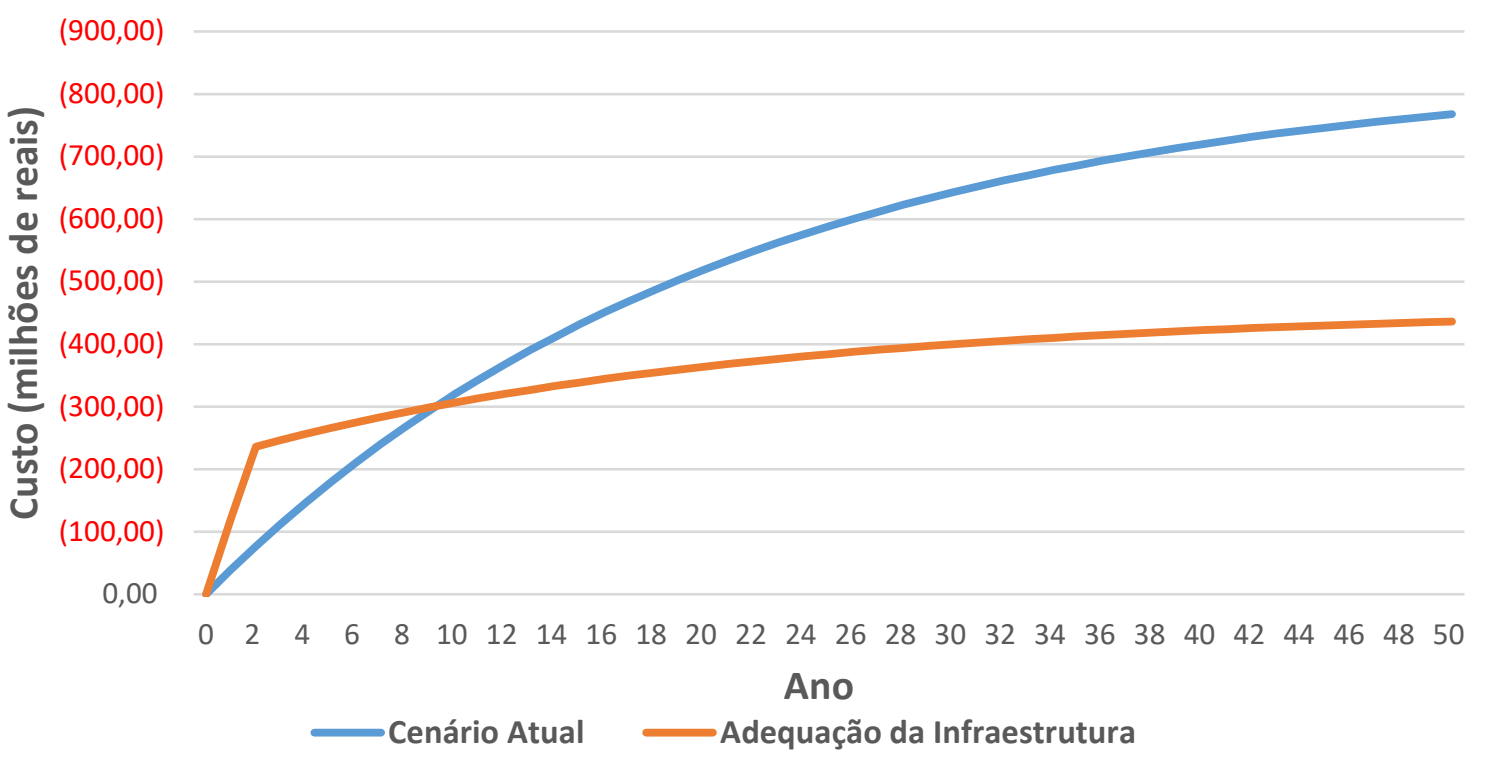

Figura 14 - Custos Diretos esperados Cenário Atual e Cenário Adequação da Infraestrutura O fluxo de caixa descontado e o fluxo de caixa descontado acumulado obtido na ACB Parcial da adequação da infraestrutura em contrapartida ao cenário atual (status quo) são apresentados respectivamente na Figura 15 e Figura 16.

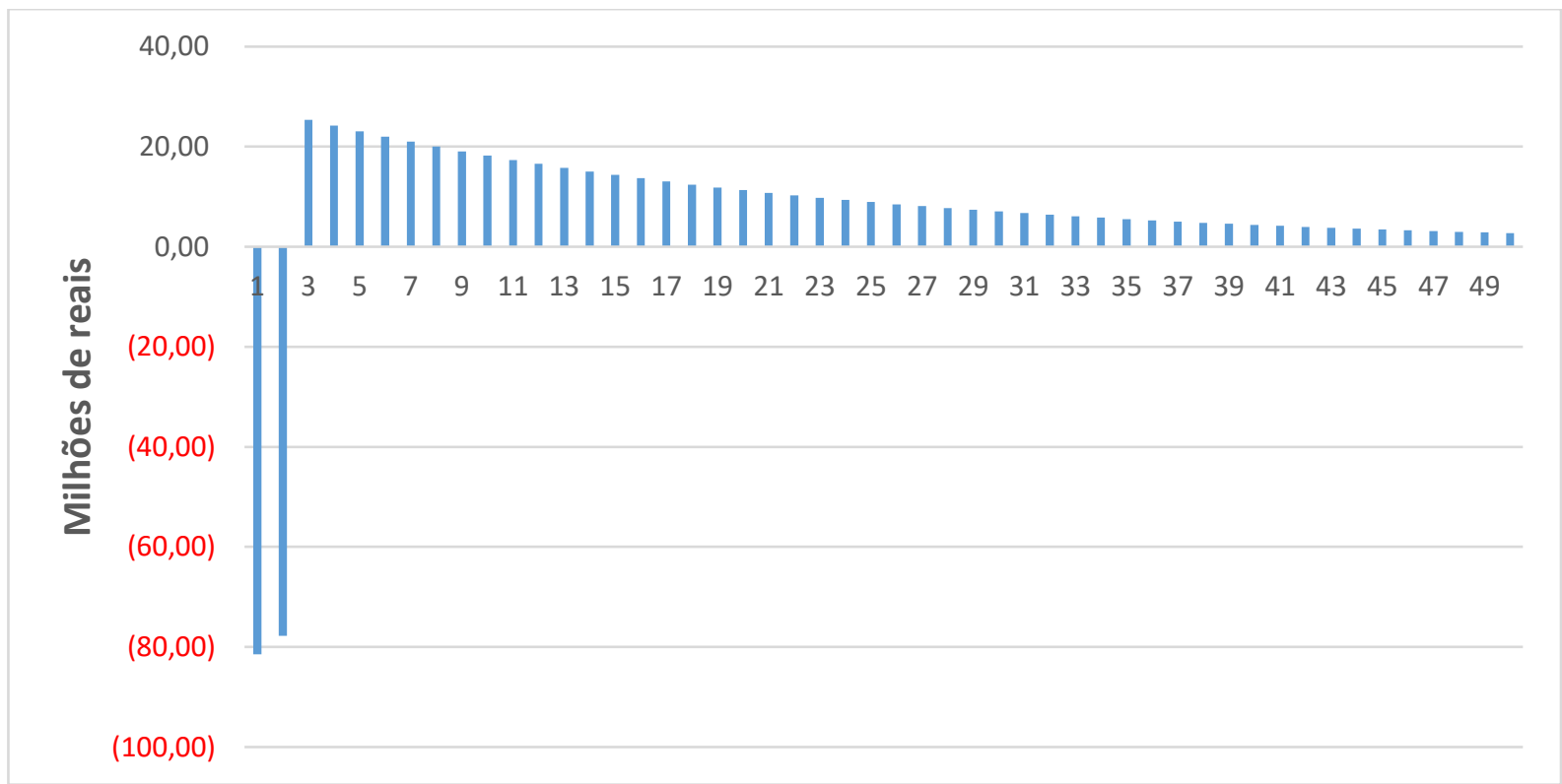

Figura 15 - Fluxo de Caixa descontado da adequação da infraestrutura em contrapartida ao cenário atual (ACB Parcial) 


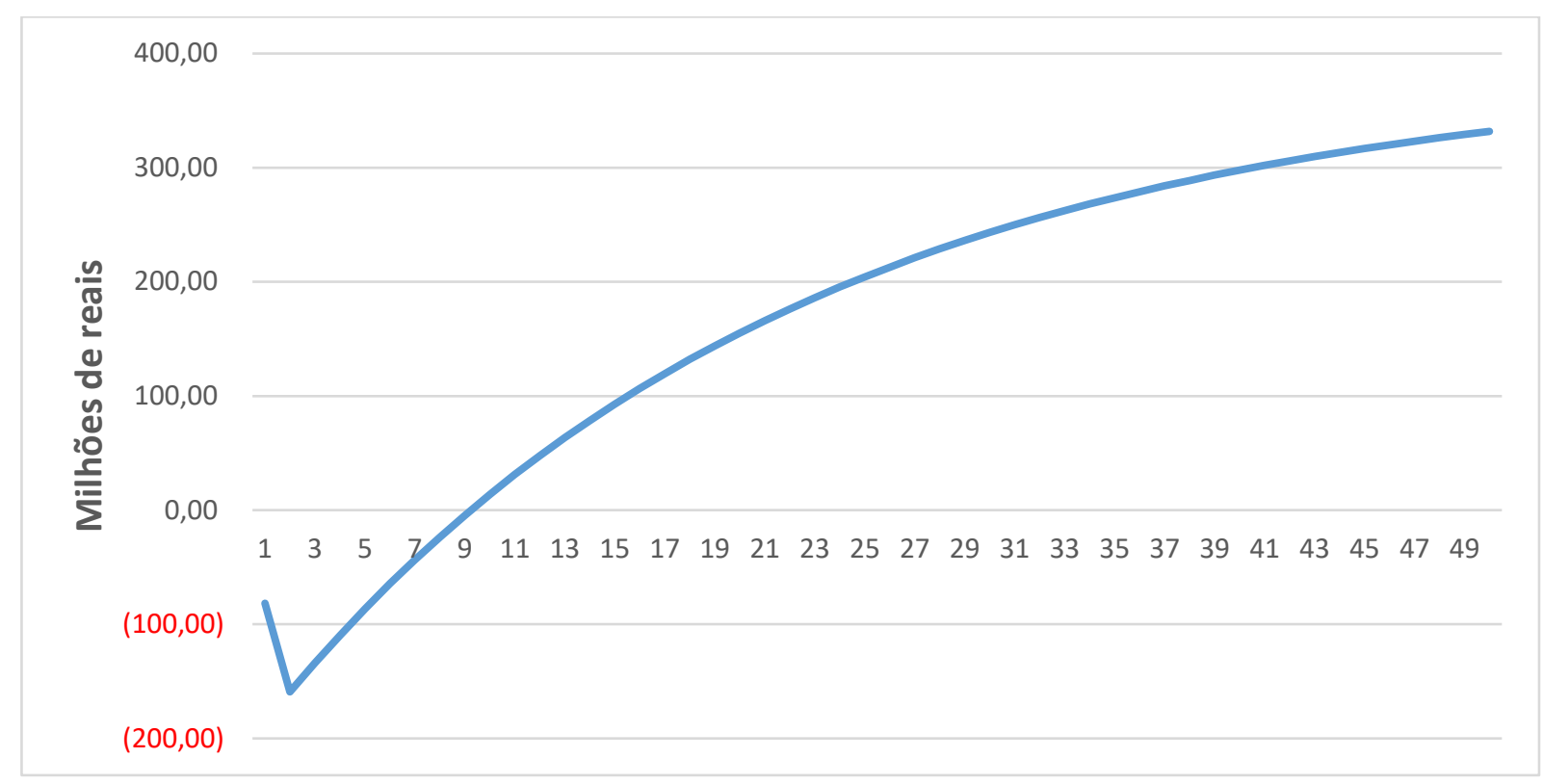

Figura 16 - Fluxo de Caixa descontado acumulado da adequação da infraestrutura em contrapartida ao cenário atual (ACB Parcial)

Foram realizadas novamente as análises de sensibilidade em função do Custo Direto do Acidente proposta em 4.3 e em função das taxas de desconto propostas. Os resultados estão apresentados no Quadro 4.

Quadro 4 - Análise de Sensibilidade da ACB Parcial

\begin{tabular}{|c|c|c|c|c|c|}
\hline \multirow{2}{*}{\multicolumn{3}{|c|}{$\begin{array}{c}\text { Análise de Sensibilidade } \\
\text { VSL } \\
\text { (milhões R\$) }\end{array}$}} & \multicolumn{3}{|c|}{ Cenários } \\
\hline & & & 4,1 & 5,1 & 8,0 \\
\hline \multicolumn{3}{|c|}{$\begin{array}{c}\text { Custo Direto do Acidente } \\
\text { (milhões R\$) }\end{array}$} & 558,6 & 665,0 & 945,6 \\
\hline \multirow{6}{*}{ 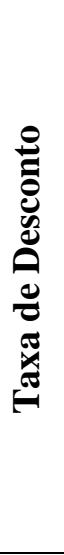 } & \multirow{3}{*}{$4,87 \%$} & VPL (R\$ milhões) & 256,7 & 331,8 & 529,9 \\
\hline & & Relação Benefício-Custo & 2,6 & 3,1 & 4,1 \\
\hline & & Payback & $\begin{array}{l}10 \text { anos e } \\
9 \text { meses }\end{array}$ & $\begin{array}{l}9 \text { anos e } \\
3 \text { meses }\end{array}$ & $\begin{array}{l}7 \text { anos e } \\
2 \text { meses }\end{array}$ \\
\hline & \multirow{3}{*}{$7 \%$} & VPL (R\$ milhões) & 146,7 & 200,6 & 342,8 \\
\hline & & Relação Benefício-Custo & 2,0 & 2,3 & 3,1 \\
\hline & & Payback & 12 anos & $\begin{array}{l}10 \text { anos e } \\
2 \text { meses }\end{array}$ & $\begin{array}{l}7 \text { anos e } \\
7 \text { meses }\end{array}$ \\
\hline \multicolumn{3}{|r|}{ TIR } & $13,7 \%$ & $15,9 \%$ & $20,9 \%$ \\
\hline
\end{tabular}


Assim, em todos os cenários avaliados na ACB Parcial, mesmo desconsiderando os custos indiretos do acidente, os benefícios esperados da adequação superam os custos incorridos. A Relação Benefício-Custo calculada para todos os cenários variou de 2,0 a 4,1 e o payback time entre 7 anos e 2 meses no mais otimista e 12 anos no mais pessimista. Dessa forma, não foi necessária a condução de análises qualitativas subsequentes para avaliar o impacto dos Custos Indiretos do Acidente Aeronáutico, já que o benefício da redução apenas dos Custos Diretos já é superior a todos os custos incorridos para a adequação do aeroporto.

Estimou-se, ainda que se fossem gastos 480 milhões de reais na Pista de Pouso e Decolagem Central do Aeroporto de Congonhas (240\% a mais do que o estimado) apenas visando a redução do risco às operações, ainda assim seria uma solução vantajosa do ponto de vista do bem-estar social mesmo desprezando os custos indiretos do acidente aeronáutico e desconsiderando todos os benefícios adicionais consequente da adequação do aeroporto.

\subsubsection{Conclusões do Estudo de Caso}

Através da realização da ACB e ACB Parcial, pode-se afirmar que, do ponto de vista de bem-estar social, que a solução da adequação da infraestrutura pela construção da Pista de Pouso e Decolagem de Congonhas Central é desejável em contrapartida da manutenção da infraestrutura em não-conformidade aos requisitos técnicos com as operações atuais do aeroporto (status quo).

Outros cenários devem ser avaliados para a escolha da melhor proposta para o aeroporto de Congonhas, podendo estes incluir custos e benefícios não avaliados nos dois cenários deste estudo, como por exemplo a expansão ou redução da pisa de pouso e decolagem, alterações da capacidade operacional e dos níveis de atrasos, ou até mesmo a alteração das operações de pouso e decolagem do aeroporto, com eventuais restrições operacionais.

Ressalta-se que este estudo focou apenas no risco do acidente aeronáutico devido às excursões laterais (veer-off) no Aeroporto de Congonhas visto que a ausência das Áreas de Segurança de Fim de Pista (RESA) está mitigada com a redução do comprimento de pista disponível para pousos e decolagens. Todavia, ao se analisar outros cenários de adequação da infraestrutura para a escolha da solução para o aeroporto, os riscos de excursões de fim de pista (overrun) podem ser estimados, bem como avaliadas alternativas para o provimento definitivo das RESA, seja através do aterramento das cabeceiras, da redução do comprimento das pistas de pouso e decolagem ou através da implantação de EMAS (Engineered Material Arresting System). 


\section{CONSIDERAÇÕES FINAIS}

A Análise de Impacto Regulatório - AIR é uma importante ferramenta para auxiliar a Agência Nacional de Aviação Civil a avaliar a adequação das Infraestruturas Aeroportuárias que estão em não-conformidade aos requisitos de Projeto de Aeródromos constantes do Regulamento Brasileiro de Aviação Civil - RBAC 154.

Pode-se afirmar que o Modelo Regulatório adotado pela ANAC, que exige a conformidade aos requisitos técnicos ou a comprovação, através de análises de risco, de que a operação do aeródromo está dentro de níveis tidos como aceitáveis, se configura na adoção de uma modalidade de AIR, uma vez que a decisão de intervir no Aeroporto e determinar a sua adequação se dá apenas quando o risco às operações é considerado como inaceitável. Todavia, não é possível concluir que esse modelo leva à alocação ótima dos recursos da sociedade, visto que não há análises que comprovem que os benefícios esperados da adequação das infraestruturas superam os custos que seriam incorridos.

A Análise de Custo-Benefício pode ser utilizada pela Agência como metodologia para subsidiar a tomada de decisão do Regulador em determinar a adequação da infraestrutura aos requisitos normativos, em especial os que demandem maiores investimentos e que não sejam necessários para garantir a interoperabilidade da aviação civil internacional. Da mesma forma, a decisão de isentar algum aeroporto do cumprimento de requisitos técnicos embasada em uma análise econômica robusta, que comprove que os benefícios esperados pela sociedade são inferiores aos custos necessários para a sua adequação, é mais apropriada para o ente regulador, visto que mostra à sociedade a preocupação do Estado na eficiência da alocação de seus recursos.

O estabelecimento de um Valor Estatístico da Vida (VSL) para a Aviação Civil Brasileira, definido como o valor ótimo que a sociedade está disposta a pagar para a redução dos riscos de morte dos passageiros, se faz necessário para a constituição dos corretos incentivos para se evitar que os acidentes aconteçam.

O valor do VSL calculado para o transporte regular de passageiros da Aviação Civil Brasileira foi de 5,1 milhões de reais para o final do ano de 2015. Sugere-se a realização de análises de sensibilidade com os valores de 4,1 e 8,0 milhões de reais em virtude da heterogeneidade do Valor Estatístico da Vida. 
Trabalhos futuros podem ser realizados para se inferir o VSL para o transporte regular de passageiros da Aviação Civil Brasileira com base na utilização de Métodos Empíricos, dos quais destacam-se, na literatura recente, os que utilizam a metodologia das Preferências Declaradas.

Foi estimado com base nos dados reais de operações e meteorologia que a probabilidade da ocorrência de excursões laterais (veer-off) no Aeroporto de Congonhas é de 3,2 x $10^{-7}$, portanto $220 \%$ maior do que o limite sugerido pela IAC 154-1001 de 1,0 x 10 ${ }^{-7}$, parâmetro normalmente utilizado na aviação civil internacional para se avaliar os riscos de acidentes catastróficos nos aeroportos. Assim, ao assumir uma curva nula de crescimento das operações de pouso e decolagem em Congonhas, o modelo de risco utilizado (ACRP) mostra que seria esperado um acidente catastrófico no aeroporto a cada 17 anos, aproximadamente.

O Custo Total esperado de um acidente aeronáutico catastrófico para o Aeroporto de Congonhas estimado nesse estudo foi de aproximadamente 1,4 bilhão de reais, podendo variar em um intervalo de 1,1 e 2,3 bilhões de reais. O Custo Direto estimado para esse acidente é de 665 milhões de reais, podendo variar em um intervalo de 559 e 946 milhões de reais.

Através da Análise de Custo-Benefício, mostrou-se que a manutenção da infraestrutura em não-conformidade às normas técnicas com o nível de operação atual existente no aeroporto não é a solução ótima do ponto de vista do bem-estar social. Neste trabalho estimou-se que a adequação da infraestrutura aos requisitos de Projeto de Aeródromos contidos no RBAC 154 reduziria o risco do acidente catastrófico a $0,92 \times 10^{-7}$, portanto $8 \%$ inferior ao parâmetro de $1,0 \times 10^{-7}$.

Uma das soluções para esta adequação é a construção de uma Pista de Pouso e Decolagem central, que mesmo desconsiderando os possíveis benefícios quanto ao aumento de capacidade e a redução dos atrasos devido a um sistema de pistas de táxi mais eficiente, levaria a benefícios, através da redução da probabilidade de acidentes, equivalente a 5,7 vezes o custo esperado para a sua construção, variando entre 3,4 no cenário mais pessimista e 7,9 no mais otimista. Caso não sejam considerados os custos indiretos de um acidente aeronáutico, ainda assim a construção dessa pista resultaria em benefícios equivalentes a 3,1 vezes o custo previsto para a adequação, podendo variar entre 2,0 no cenário mais pessimista a 4,1 no mais otimista. 
A Análise de Custo-Benefício do Aeroporto de Congonhas realizada neste estudo mostrou que, mesmo que a adequação do aeroporto incorresse em um custo de aproximadamente 1 bilhão de reais e ainda que não fosse esperado nenhum benefício adicional a não ser a redução do risco de acidentes proveniente da adequação da infraestrutura às normas técnicas, ainda assim esta adequação seria desejável do ponto de vista do bem-estar social. 


\section{REFERÊNCIAS BIBLIOGRÁFICAS}

ABEAR. Panorama 2013. Disponível em: < http://www.abear.com.br/dados-efatos/panorama-abear> Acesso em: 30 jun. 2016

ANAC. IAC 121-1013, Procedimentos e requisitos técnico-operacionais complementares para operação no aeroporto de Congonhas. D.O.U. de 01/04/2008; Seção 1, p. 16, 2008.

ANAC. Regulamento Brasileiro de Aviação Civil - RBAC 154 - Projeto de Aeródromos. D.O.U. de 12/05/2009; Seção 1, p. 148.

ANAC. Decisão $N^{\circ}$ 134, de 17/09/2014. Fixa a interpretação a respeito da aplicabilidade de dispositivos do RBAC nº 154. D.O.U. de 19/09/2014; Seção 1, p. 4.

ANAC. Regulamento Brasileiro de Aviação Civil - RBAC 139 - Certificação Operacional de Aeroportos. Emenda 05, D.O.U. de 15/12/2015; Seção 1, p. 6.

ANAC. Organização da Aviação Civil Internacional (OACI). Disponível em: <http://www.anac.gov.br/A_Anac/internacional/organismos-internacionais/organizacao-daaviacao-civil-internacional-oaci>. Acesso em: 03 de set. 2016.

ARROW, K. J. et. al., Benefit-Cost Analysis in Environmental, Health, and Safety Regulation - A Statement of Principles. American Enterprise Institute for Public Policy Research. Washington, D.C., 1996.

BRASIL. Decreto $\mathbf{n}^{0}$ 21.713, de 27/08/1946. Promulga a Convenção sobre Aviação Civil Internacional, concluída em Chicago a 7 de dezembro de 1944 e firmado pelo Brasil, em Washington, a 29 de maio de 1945. DOFC de 12/09/1946, p. 12715.

BRASIL. Ministério da Aeronáutica. Portaria no 398/GM5, de 04/06/1999. Dispõe sobre a aplicação do Anexo 14 à Convenção de Aviação Civil Internacional no Território Nacional. D.O.U. de 07/07/1999; Seção 1, p. 11.

BRODER, I. E.; MORRALL III, J. F. Collecting and Using Data for Regulatory DecisionMaking. In: OCDE. Regulatory Impact Analysis: Best Practices in OECD Countries. cap.10, Paris, 1997. 
CAVKA, I.; COKORILO, O. Cost - Benefit Assessment of Aircraft Safety. International Journal for Traffic and Transport Engineering, 2(4), p 359-371, 2012.

COMAER. NSCA 3-13, Protocolos de Investigação de Ocorrências Aeronáuticas da Aviação Civil Conduzidas pelo Estado Brasileiro. 2013.

DAC. IAC 154-1001, Termo de referência para estudo aeronáutico. D.O.U. de 19/10/2004; Seção 1, p. 7.

DRÈZE, J. L'utilité sociale d'une vie humaine. Revue Francaise de Recherche Opérationelle, 23, p. 93-118, 1962.

DUBLIN, L. I.; LOTKA, A. J. The money value of a man. New York: Ronald Press, 1930. EDDOWES, M.; HANCOX, J.; MACINNES, A. Final Report on the Risk Analysis in Support of Aerodrome Design Rules. AEA Technology, Noruega, 2001.

EUROPEAN COMMISSION, Annexes to Impact Assessment Guidelines. 2009.

FAA. Economic Analysis of Investment and Regulatory Decisions - Revised Guide, Section 2: Treatment of the values of life and injury in economic analysis, 2014.

FARR, W. The Income and Property Tax. Journal of the Statistical Society of London, London, 1853.

GAETANI, F.; ALBUQUERQUE, K., Análise de impacto regulatório e melhoria regulatória. In: RAMALHO, P. I. S. Regulação e Agências Reguladoras - Governança e Análise de Impacto Regulatório. cap.8, Brasília, DF, 2009.

HAHN, R. W.; LITAN, R. E. Recommendations for Improving Regulatory Accountability and Transparency. 2003.

HALL, J. W. et. al., ACRP Report 51: Risk Assessment Method to Support Modification of Airfield Separation Standards, Transportation Research Board of the National Academies, Washington, D.C, 2011.

HAMMITT, J. K.; GRAHAM, J. D. Willingness to Pay for Health Protection: Inadequate Sensitivity to Probability? The Journal of Risk and Uncertainty, 8. p 33-62, 1999. 
INFRAERO. Aeroporto de São Paulo/Congonhas. Disponível em:

<http://www.infraero.gov.br/index.php/aeroportos/sao-paulo/aeroporto-de-sao-paulocongonhas.html>. Acesso em: 10 jun. 2016

LINDHJEM, H. et. al., Valuing mortality risk reductions from environmental, transport and health policies: A global meta-analysis of stated preference studies. Risk Analysis. Volume 31, Issue 9, 2011.

NLR - National Aerospace Laboratory. Aviation Safety Targets for Efective Regulation, Consolidated Final Report. 2001.

NOVA ZELÂNDIA, Making New Standards and Recommended Practices: Impact Assessment. Working Paper A37-WP/114. OACI. Montreal, 2010.

OACI, Annex 14 - Aeródromos. 1a edição. Montreal, 1951.

OACI, Annex 14 - Aeródromos. $7^{\text {a }}$ edição. Montreal, 1976.

OACI, Annex 14 - Aeródromos. $8^{\text {a }}$ edição. Montreal, 1983.

OACI, Annex 14: Aeródromos, Aerodrome Design and Operations. Volume I, $3^{\text {a }}$ edição. Montreal, 1999.

OACI, Annex 14: Aeródromos, Aerodrome Design and Operations. Volume I, $6^{\mathrm{a}}$ edição. Montreal, 2013.

OACI. Annex 10 - Safety Management. Montreal, 2013a.

OACI. DOC 9859 - Safety Management Manual (SMM). $3^{\text {a }}$ edição. Montreal, 2013b.

OACI. DOC 9981 - Procedures for Air Navigation Services - Aerodromes (PANSAerodromes. Montreal, 2015.

OACI. About ICAO. <http://www.icao.int/about-icao/Pages/default.aspx>. Acesso em: 03 de set. 2016.

OCDE. Introductory Handbook for Undertaking Regulatory Impact Analysis (RIA). Paris, 2008. 
OCDE. Determinants of Quality in Regulatory Impact Analysis. In: Regulatory Impact Analysis - A Tool For Policy Coherence. cap.2. Paris, 2009a.

OCDE. Methodological Frameworks for Regulatory Impact Analysis: Valuation, Risk And Benefit-Cost Analysis. In: Regulatory Impact Analysis - A Tool For Policy Coherence. cap.3. Paris, 2009 b.

OCDE. Valuing Lives Saved from Environmental, Transport and Health Policies: A MetaAnalysis of Stated Preference Studies. Paris, 2010.

OCDE. Valuing Mortality Risk Reductions in Regulatory Analysis of Environmental, Health and Transport Policies, Paris, 2011.

PRATT, J. W.; ZECKHAUSER, R. J., Willingness to Pay and the Distribution of Risk and Wealth. Journal of Political Economy, 1996.

RABBANI, F. F. R.; MOSER, R. F. Improving Safety and Capacity at Old Airports: A Revolutionary Layout Shift FOR São Paulo/Congonhas Runway System. 14th ATRS World Conference, 2010, Porto. ATRS World Conference, 2010.

RAMOS, M. Governança regulatória: experiências e contribuições para uma melhor qualidade Regulatória. In: RAMALHO, P. I. S. Regulação e Agências Reguladoras - Governança e Análise de Impacto Regulatório. cap.9, Brasília, 2009.

ROSEN, S. The theory of equalizing differences. In Handbook of Labor Economics, ed. O. Ashenfelter and R. Layard. Amsterdam, 1986.

SCHELling, T. C. The Life You Save May Be Your Own. In: Chase Jr., S. B.,Problems in Public Expenditure and Analysis. Washington, DC: Brookings Institution, p. 127-162, 1968.

VISCUSI, W. K.; Vernon, J. M.; Harrington, J. E. Economics of Regulation and Antitrust. Ed. MIT Press, $2^{\text {a }}$ edição, 1992.

VISCUSI, W. K. Mortality Effects of Regulatory Costs and Policy Evaluation Criteria. Rand Journal of Economics 25 (1), p 94-109, 1994.

VISCUSI, W. K. Improving the Analytical Basis for Regulatory Decision-Making. In: OCDE. Regulatory Impact Analysis: Best Practices in OECD Countries. cap.10. Paris, 1997. 
VISCUSI, W. K. The Value of Life. New Palgrave Dictionary of Economics and the Law, $2^{\mathrm{a}}$ edição; Vanderbilt Law and Economics Research Paper No. 08-04, 2005.

VISCUSI, W. K. The Heterogeneity of the Value of Statistical Life: Introduction and Overview. Journal of Risk and Uncertainty, Vol. 40, No. 1, 2010.

VISCUSI, W. K.; ALDY, J. E. The Value of a Statistical Life: A Critical Review of Market Estimates throughout the World. Journal of Risk and Uncertainty, 27(1), p. 5-76, 2003. 
APÊNDICE A - CÁLCULO DO VSL

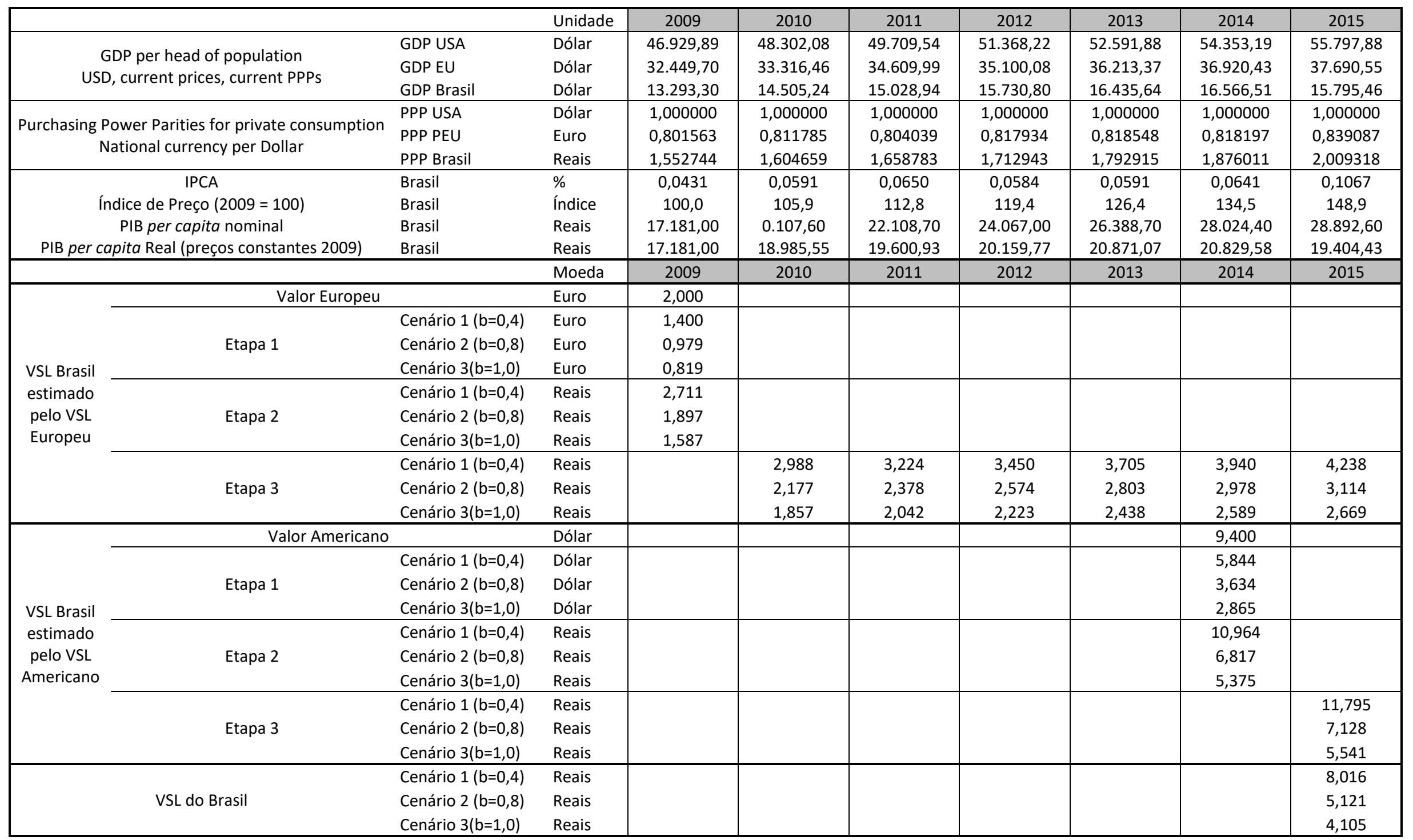


APÊNDICE B - FLUXO DE CAIXA MARGINAL DA ANÁLISE DE CUSTO-BENEFÍCIO

\begin{tabular}{|c|c|c|c|c|c|c|c|c|c|c|}
\hline Análise de Custo-Benefício & 1 & 2 & 3 & 4 & $\begin{array}{l}\text { An } \\
5 \\
\end{array}$ & 6 & 7 & 8 & 9 & 10 \\
\hline Risco (por 10.000 .000 ops) & & & & & & & & & & \\
\hline Infraestrutura Atual & 3,179 & 3,175 & 3,175 & 3,175 & 3,175 & 3,175 & 3,175 & 3,175 & 3,175 & 3,175 \\
\hline Pista Central & 4,066 & 4,066 & 0,919 & 0,919 & 0,919 & 0,919 & 0,919 & 0,919 & 0,919 & 0,919 \\
\hline Operações anuais & 186.129 & 186.129 & 186.129 & 186.129 & 186.129 & 186.129 & 186.129 & 186.129 & 186.129 & 186.129 \\
\hline Acidentes esperados & & & & & & & & & & \\
\hline Infraestrutura Atual & 0,06 & 0,06 & 0,06 & 0,06 & 0,06 & 0,06 & 0,06 & 0,06 & 0,06 & 0,06 \\
\hline Pista Central & 0,08 & 0,08 & 0,02 & 0,02 & 0,02 & 0,02 & 0,02 & 0,02 & 0,02 & 0,02 \\
\hline Custo do Acidente & $(1429,76)$ & $(1429,76)$ & $(1429,76)$ & $(1429,76)$ & $(1429,76)$ & $(1429,76)$ & $(1429,76)$ & $(1429,76)$ & $(1429,76)$ & $(1429,76)$ \\
\hline Taxa de desconto & $4,87 \%$ & & & & & & & & & \\
\hline Cenário atual & & & & & & & & & & \\
\hline Custo do Risco Esperado & $(84,60)$ & $(84,48)$ & $(84,48)$ & $(84,48)$ & $(84,48)$ & $(84,48)$ & $(84,48)$ & $(84,48)$ & $(84,48)$ & $(84,48)$ \\
\hline Descontado & $(84,60)$ & $(80,56)$ & $(76,82)$ & $(73,25)$ & $(69,85)$ & $(66,61)$ & $(63,52)$ & $(60,57)$ & $(57,76)$ & $(55,07)$ \\
\hline Descontado e Acumulado & $(84,60)$ & $(165,16)$ & $(241,98)$ & $(315,24)$ & $(385,09)$ & $(451,70)$ & $(515,21)$ & $(575,78)$ & $(633,54)$ & $(688,61)$ \\
\hline Cenário alternativo & & & & & & & & & & \\
\hline Custo do Risco Esperado & $(108,20)$ & $(108,20)$ & $(24,45)$ & $(24,45)$ & $(24,45)$ & $(24,45)$ & $(24,45)$ & $(24,45)$ & $(24,45)$ & $(24,45)$ \\
\hline Descontado & $(108,20)$ & $(103,18)$ & $(22,23)$ & $(21,20)$ & $(20,22)$ & $(19,28)$ & $(18,38)$ & $(17,53)$ & $(16,72)$ & $(15,94)$ \\
\hline Custo de adequação & $(70,50)$ & $(70,50)$ & & & & & & & & \\
\hline Descontado & $(70,50)$ & $(67,23)$ & & & & & & & & \\
\hline Custo Total Descontado & $(178,70)$ & $(170,40)$ & $(22,23)$ & $(21,20)$ & $(20,22)$ & $(19,28)$ & $(18,38)$ & $(17,53)$ & $(16,72)$ & $(15,94)$ \\
\hline Descontado e Acumulado & $(178,70)$ & $(349,11)$ & $(371,34)$ & $(392,54)$ & $(412,76)$ & $(432,04)$ & $(450,42)$ & $(467,95)$ & $(484,67)$ & $(500,61)$ \\
\hline Cenário atual $\mathrm{x}$ alternativo & & & & & & & & & & \\
\hline Resultado da redução do risco & $(23,60)$ & $(23,72)$ & 60,03 & 60,03 & 60,03 & 60,03 & 60,03 & 60,03 & 60,03 & 60,03 \\
\hline Descontado & $(23,60)$ & $(22,62)$ & 54,59 & 52,05 & 49,63 & 47,33 & 45,13 & 43,04 & 41,04 & 39,13 \\
\hline Custo de adequação & $(70,50)$ & $(70,50)$ & & & & & & & & \\
\hline Descontado & $(70,50)$ & $(67,23)$ & & & & & & & & \\
\hline Fluxo de caixa Descontado & $(94,10)$ & $(89,84)$ & 54,59 & 52,05 & 49,63 & 47,33 & 45,13 & 43,04 & 41,04 & 39,13 \\
\hline Descontado e Acumulado & $(94,10)$ & $(183,94)$ & $(129,36)$ & $(77,31)$ & $(27,67)$ & 19,66 & 64,79 & 107,83 & 148,87 & 188,00 \\
\hline
\end{tabular}




\begin{tabular}{|c|c|c|c|c|c|c|c|c|c|c|}
\hline \multirow[b]{2}{*}{ Análise de Custo-Benefício } & \multicolumn{10}{|c|}{ Ano } \\
\hline & 11 & 12 & 13 & 14 & 15 & 16 & 17 & 18 & 19 & 20 \\
\hline \multicolumn{11}{|l|}{ Risco (por 10.000 .000 ops) } \\
\hline Infraestrutura Atual & 3,175 & 3,175 & 3,175 & 3,175 & 3,175 & 3,175 & 3,175 & 3,175 & 3,175 & 3,175 \\
\hline Pista Central & 0,919 & 0,919 & 0,919 & 0,919 & 0,919 & 0,919 & 0,919 & 0,919 & 0,919 & 0,919 \\
\hline Operações anuais & 186.129 & 186.129 & 186.129 & 186.129 & 186.129 & 186.129 & 186.129 & 186.129 & 186.129 & 186.129 \\
\hline \multicolumn{11}{|l|}{ Acidentes esperados } \\
\hline Infraestrutura Atual & 0,06 & 0,06 & 0,06 & 0,06 & 0,06 & 0,06 & 0,06 & 0,06 & 0,06 & 0,06 \\
\hline Pista Central & 0,02 & 0,02 & 0,02 & 0,02 & 0,02 & 0,02 & 0,02 & 0,02 & 0,02 & 0,02 \\
\hline Custo do Acidente & $(1429,76)$ & $(1429,76)$ & $(1429,76)$ & $(1429,76)$ & $(1429,76)$ & $(1429,76)$ & $(1429,76)$ & $(1429,76)$ & $(1429,76)$ & $(1429,76)$ \\
\hline \multicolumn{11}{|l|}{ Taxa de desconto } \\
\hline \multicolumn{11}{|l|}{ Cenário atual } \\
\hline Custo do Risco Esperado & $(84,48)$ & $(84,48)$ & $(84,48)$ & $(84,48)$ & $(84,48)$ & $(84,48)$ & $(84,48)$ & $(84,48)$ & $(84,48)$ & $(84,48)$ \\
\hline Descontado & $(52,52)$ & $(50,08)$ & $(47,75)$ & $(45,54)$ & $(43,42)$ & $(41,41)$ & $(39,48)$ & $(37,65)$ & $(35,90)$ & $(34,23)$ \\
\hline Descontado e Acumulado & $(741,13)$ & $(791,20)$ & $(838,96)$ & $(884,49)$ & $(927,91)$ & $(969,32)$ & $(1008,80)$ & $(1046,45)$ & $(1082,35)$ & $(1116,59)$ \\
\hline \multicolumn{11}{|l|}{ Cenário alternativo } \\
\hline Custo do Risco Esperado & $(24,45)$ & $(24,45)$ & $(24,45)$ & $(24,45)$ & $(24,45)$ & $(24,45)$ & $(24,45)$ & $(24,45)$ & $(24,45)$ & $(24,45)$ \\
\hline Descontado & $(15,20)$ & $(14,49)$ & $(13,82)$ & $(13,18)$ & $(12,57)$ & $(11,98)$ & $(11,43)$ & $(10,90)$ & $(10,39)$ & $(9,91)$ \\
\hline \multicolumn{11}{|l|}{ Custo de adequação } \\
\hline Custo Total Descontado & $(15,20)$ & $(14,49)$ & $(13,82)$ & $(13,18)$ & $(12,57)$ & $(11,98)$ & $(11,43)$ & $(10,90)$ & $(10,39)$ & $(9,91)$ \\
\hline Descontado e Acumulado & $(515,81)$ & $(530,30)$ & $(544,12)$ & $(557,30)$ & $(569,87)$ & $(581,85)$ & $(593,28)$ & $(604,18)$ & $(614,57)$ & $(624,48)$ \\
\hline \multicolumn{11}{|l|}{ Cenário atual $\mathrm{x}$ alternativo } \\
\hline Resultado da redução do risco & 60,03 & 60,03 & 60,03 & 60,03 & 60,03 & 60,03 & 60,03 & 60,03 & 60,03 & 60,03 \\
\hline Descontado & 37,32 & 35,58 & 33,93 & 32,36 & 30,85 & 29,42 & 28,06 & 26,75 & 25,51 & 24,33 \\
\hline \multicolumn{11}{|l|}{ Custo de adequação } \\
\hline Fluxo de caixa Descontado & 37,32 & 35,58 & 33,93 & 32,36 & 30,85 & 29,42 & 28,06 & 26,75 & 25,51 & 24,33 \\
\hline Descontado e Acumulado & 225,32 & 260,90 & 294,83 & 327,19 & 358,05 & 387,47 & 415,52 & 442,28 & 467,79 & 492,11 \\
\hline
\end{tabular}




\begin{tabular}{|c|c|c|c|c|c|c|c|c|c|c|}
\hline \multirow[b]{2}{*}{ Análise de Custo-Benefício } & \multicolumn{10}{|c|}{ Ano } \\
\hline & 21 & 22 & 23 & 24 & 25 & 26 & 27 & 28 & 29 & 30 \\
\hline \multicolumn{11}{|l|}{ Risco (por 10.000 .000 ops) } \\
\hline Infraestrutura Atual & 3,175 & 3,175 & 3,175 & 3,175 & 3,175 & 3,175 & 3,175 & 3,175 & 3,175 & 3,175 \\
\hline Pista Central & 0,919 & 0,919 & 0,919 & 0,919 & 0,919 & 0,919 & 0,919 & 0,919 & 0,919 & 0,919 \\
\hline Operações anuais & 186.129 & 186.129 & 186.129 & 186.129 & 186.129 & 186.129 & 186.129 & 186.129 & 186.129 & 186.129 \\
\hline \multicolumn{11}{|l|}{ Acidentes esperados } \\
\hline Infraestrutura Atual & 0,06 & 0,06 & 0,06 & 0,06 & 0,06 & 0,06 & 0,06 & 0,06 & 0,06 & 0,06 \\
\hline Pista Central & 0,02 & 0,02 & 0,02 & 0,02 & 0,02 & 0,02 & 0,02 & 0,02 & 0,02 & 0,02 \\
\hline Custo do Acidente & $(1429,76)$ & $(1429,76)$ & $(1429,76)$ & $(1429,76)$ & $(1429,76)$ & $(1429,76)$ & $(1429,76)$ & $(1429,76)$ & $(1429,76)$ & $(1429,76)$ \\
\hline \multicolumn{11}{|l|}{ Taxa de desconto } \\
\hline \multicolumn{11}{|l|}{ Cenário atual } \\
\hline Custo do Risco Esperado & $(84,48)$ & $(84,48)$ & $(84,48)$ & $(84,48)$ & $(84,48)$ & $(84,48)$ & $(84,48)$ & $(84,48)$ & $(84,48)$ & $(84,48)$ \\
\hline Descontado & $(32,65)$ & $(31,13)$ & $(29,68)$ & $(28,31)$ & $(26,99)$ & $(25,74)$ & $(24,54)$ & $(23,40)$ & $(22,32)$ & $(21,28)$ \\
\hline Descontado e Acumulado & $(1149,23)$ & $(1180,36)$ & $(1210,05)$ & $(1238,35)$ & $(1265,35)$ & $(1291,08)$ & $(1315,63)$ & $(1339,03)$ & $(1361,35)$ & $(1382,63)$ \\
\hline \multicolumn{11}{|l|}{ Cenário alternativo } \\
\hline Custo do Risco Esperado & $(24,45)$ & $(24,45)$ & $(24,45)$ & $(24,45)$ & $(24,45)$ & $(24,45)$ & $(24,45)$ & $(24,45)$ & $(24,45)$ & $(24,45)$ \\
\hline Descontado & $(9,45)$ & $(9,01)$ & $(8,59)$ & $(8,19)$ & $(7,81)$ & $(7,45)$ & $(7,10)$ & $(6,77)$ & $(6,46)$ & $(6,16)$ \\
\hline \multicolumn{11}{|l|}{ Custo de adequação } \\
\hline Descontado & & & & & & & & & & \\
\hline Custo Total Descontado & $(9,45)$ & $(9,01)$ & $(8,59)$ & $(8,19)$ & $(7,81)$ & $(7,45)$ & $(7,10)$ & $(6,77)$ & $(6,46)$ & $(6,16)$ \\
\hline Descontado e Acumulado & $(633,92)$ & $(642,93)$ & $(651,53)$ & $(659,72)$ & $(667,53)$ & $(674,98)$ & $(682,08)$ & $(688,86)$ & $(695,32)$ & $(701,48)$ \\
\hline \multicolumn{11}{|l|}{ Cenário atual $\mathrm{x}$ alternativo } \\
\hline Resultado da redução do risco & 60,03 & 60,03 & 60,03 & 60,03 & 60,03 & 60,03 & 60,03 & 60,03 & 60,03 & 60,03 \\
\hline Descontado & 23,20 & 22,12 & 21,09 & 20,11 & 19,18 & 18,29 & 17,44 & 16,63 & 15,86 & 15,12 \\
\hline \multicolumn{11}{|l|}{ Custo de adequação } \\
\hline Descontado & & & & & & & & & & \\
\hline Fluxo de caixa Descontado & 23,20 & 22,12 & 21,09 & 20,11 & 19,18 & 18,29 & 17,44 & 16,63 & 15,86 & 15,12 \\
\hline Descontado e Acumulado & 515,31 & 537,43 & 558,52 & 578,63 & 597,81 & 616,10 & 633,54 & 650,17 & 666,03 & 681,15 \\
\hline
\end{tabular}




\begin{tabular}{|c|c|c|c|c|c|c|c|c|c|c|}
\hline \multirow[b]{2}{*}{ Análise de Custo-Benefício } & \multicolumn{10}{|c|}{ Ano } \\
\hline & 31 & 32 & 33 & 34 & 35 & 36 & 37 & 38 & 39 & 40 \\
\hline \multicolumn{11}{|l|}{ Risco (por 10.000 .000 ops) } \\
\hline Infraestrutura Atual & 3,175 & 3,175 & 3,175 & 3,175 & 3,175 & 3,175 & 3,175 & 3,175 & 3,175 & 3,175 \\
\hline Pista Central & 0,919 & 0,919 & 0,919 & 0,919 & 0,919 & 0,919 & 0,919 & 0,919 & 0,919 & 0,919 \\
\hline Operações anuais & 186.129 & 186.129 & 186.129 & 186.129 & 186.129 & 186.129 & 186.129 & 186.129 & 186.129 & 186.129 \\
\hline \multicolumn{11}{|l|}{ Acidentes esperados } \\
\hline Infraestrutura Atual & 0,06 & 0,06 & 0,06 & 0,06 & 0,06 & 0,06 & 0,06 & 0,06 & 0,06 & 0,06 \\
\hline Pista Central & 0,02 & 0,02 & 0,02 & 0,02 & 0,02 & 0,02 & 0,02 & 0,02 & 0,02 & 0,02 \\
\hline Custo do Acidente & $(1429,76)$ & $(1429,76)$ & $(1429,76)$ & $(1429,76)$ & $(1429,76)$ & $(1429,76)$ & $(1429,76)$ & $(1429,76)$ & $(1429,76)$ & $(1429,76)$ \\
\hline \multicolumn{11}{|l|}{ Taxa de desconto } \\
\hline \multicolumn{11}{|l|}{ Cenário atual } \\
\hline Custo do Risco Esperado & $(84,48)$ & $(84,48)$ & $(84,48)$ & $(84,48)$ & $(84,48)$ & $(84,48)$ & $(84,48)$ & $(84,48)$ & $(84,48)$ & $(84,48)$ \\
\hline Descontado & $(20,29)$ & $(19,35)$ & $(18,45)$ & $(17,60)$ & $(16,78)$ & $(16,00)$ & $(15,26)$ & $(14,55)$ & $(13,87)$ & $(13,23)$ \\
\hline Descontado e Acumulado & $(1402,92)$ & $(1422,27)$ & $(1440,73)$ & $(1458,32)$ & $(1475,10)$ & $(1491,10)$ & $(1506,36)$ & $(1520,90)$ & $(1534,78)$ & $(1548,01)$ \\
\hline \multicolumn{11}{|l|}{ Cenário alternativo } \\
\hline Custo do Risco Esperado & $(24,45)$ & $(24,45)$ & $(24,45)$ & $(24,45)$ & $(24,45)$ & $(24,45)$ & $(24,45)$ & $(24,45)$ & $(24,45)$ & $(24,45)$ \\
\hline Descontado & $(5,87)$ & $(5,60)$ & $(5,34)$ & $(5,09)$ & $(4,86)$ & $(4,63)$ & $(4,42)$ & $(4,21)$ & $(4,02)$ & $(3,83)$ \\
\hline \multicolumn{11}{|l|}{ Custo de adequação } \\
\hline Descontado & & & & & & & & & & \\
\hline Custo Total Descontado & $(5,87)$ & $(5,60)$ & $(5,34)$ & $(5,09)$ & $(4,86)$ & $(4,63)$ & $(4,42)$ & $(4,21)$ & $(4,02)$ & $(3,83)$ \\
\hline Descontado e Acumulado & $(707,35)$ & $(712,95)$ & $(718,29)$ & $(723,38)$ & $(728,24)$ & $(732,87)$ & $(737,29)$ & $(741,50)$ & $(745,51)$ & $(749,34)$ \\
\hline \multicolumn{11}{|l|}{ Cenário atual $\mathrm{x}$ alternativo } \\
\hline Resultado da redução do risco & 60,03 & 60,03 & 60,03 & 60,03 & 60,03 & 60,03 & 60,03 & 60,03 & 60,03 & 60,03 \\
\hline Descontado & 14,42 & 13,75 & 13,11 & 12,50 & 11,92 & 11,37 & 10,84 & 10,34 & 9,86 & 9,40 \\
\hline \multicolumn{11}{|l|}{ Custo de adequação } \\
\hline Descontado & & & & & & & & & & \\
\hline Fluxo de caixa Descontado & 14,42 & 13,75 & 13,11 & 12,50 & 11,92 & 11,37 & 10,84 & 10,34 & 9,86 & 9,40 \\
\hline Descontado e Acumulado & 695,57 & 709,32 & 722,43 & 734,94 & 746,86 & 758,23 & 769,07 & 779,41 & 789,26 & 798,66 \\
\hline
\end{tabular}




\begin{tabular}{|c|c|c|c|c|c|c|c|c|c|c|}
\hline \multirow[b]{2}{*}{ Análise de Custo-Benefício } & \multicolumn{10}{|c|}{ Ano } \\
\hline & 41 & 42 & 43 & 44 & 45 & 46 & 47 & 48 & 49 & 50 \\
\hline \multicolumn{11}{|l|}{ Risco (por 10.000 .000 ops) } \\
\hline Infraestrutura Atual & 3,175 & 3,175 & 3,175 & 3,175 & 3,175 & 3,175 & 3,175 & 3,175 & 3,175 & 3,175 \\
\hline Pista Central & 0,919 & 0,919 & 0,919 & 0,919 & 0,919 & 0,919 & 0,919 & 0,919 & 0,919 & 0,919 \\
\hline Operações anuais & 186.129 & 186.129 & 186.129 & 186.129 & 186.129 & 186.129 & 186.129 & 186.129 & 186.129 & 186.129 \\
\hline \multicolumn{11}{|l|}{ Acidentes esperados } \\
\hline Infraestrutura Atual & 0,06 & 0,06 & 0,06 & 0,06 & 0,06 & 0,06 & 0,06 & 0,06 & 0,06 & 0,06 \\
\hline Pista Central & 0,02 & 0,02 & 0,02 & 0,02 & 0,02 & 0,02 & 0,02 & 0,02 & 0,02 & 0,02 \\
\hline Custo do Acidente & $(1429,76)$ & $(1429,76)$ & $(1429,76)$ & $(1429,76)$ & $(1429,76)$ & $(1429,76)$ & $(1429,76)$ & $(1429,76)$ & $(1429,76)$ & $(1429,76)$ \\
\hline \multicolumn{11}{|l|}{ Taxa de desconto } \\
\hline \multicolumn{11}{|l|}{ Cenário atual } \\
\hline Custo do Risco Esperado & $(84,48)$ & $(84,48)$ & $(84,48)$ & $(84,48)$ & $(84,48)$ & $(84,48)$ & $(84,48)$ & $(84,48)$ & $(84,48)$ & $(84,48)$ \\
\hline Descontado & $(12,61)$ & $(12,03)$ & $(11,47)$ & $(10,94)$ & $(10,43)$ & $(9,95)$ & $(9,48)$ & $(9,04)$ & $(8,62)$ & $(8,22)$ \\
\hline Descontado e Acumulado & $(1560,62)$ & $(1572,65)$ & $(1584,12)$ & $(1595,06)$ & $(1605,49)$ & $(1615,43)$ & $(1624,92)$ & $(1633,96)$ & $(1642,58)$ & $(1650,81)$ \\
\hline \multicolumn{11}{|l|}{ Cenário alternativo } \\
\hline Custo do Risco Esperado & $(24,45)$ & $(24,45)$ & $(24,45)$ & $(24,45)$ & $(24,45)$ & $(24,45)$ & $(24,45)$ & $(24,45)$ & $(24,45)$ & $(24,45)$ \\
\hline Descontado & $(3,65)$ & $(3,48)$ & $(3,32)$ & $(3,17)$ & $(3,02)$ & $(2,88)$ & $(2,74)$ & $(2,62)$ & $(2,50)$ & $(2,38)$ \\
\hline \multicolumn{11}{|l|}{ Custo de adequação } \\
\hline Descontado & & & & & & & & & & \\
\hline Custo Total Descontado & $(3,65)$ & $(3,48)$ & $(3,32)$ & $(3,17)$ & $(3,02)$ & $(2,88)$ & $(2,74)$ & $(2,62)$ & $(2,50)$ & $(2,38)$ \\
\hline Descontado e Acumulado & $(752,99)$ & $(756,47)$ & $(759,79)$ & $(762,96)$ & $(765,98)$ & $(768,86)$ & $(771,60)$ & $(774,22)$ & $(776,71)$ & $(779,09)$ \\
\hline \multicolumn{11}{|l|}{ Cenário atual $\mathrm{x}$ alternativo } \\
\hline Resultado da redução do risco & 60,03 & 60,03 & 60,03 & 60,03 & 60,03 & 60,03 & 60,03 & 60,03 & 60,03 & 60,03 \\
\hline Descontado & 8,96 & 8,55 & 8,15 & 7,77 & 7,41 & 7,07 & 6,74 & 6,43 & 6,13 & 5,84 \\
\hline \multicolumn{11}{|l|}{ Custo de adequação } \\
\hline Descontado & & & & & & & & & & \\
\hline Fluxo de caixa Descontado & 8,96 & 8,55 & 8,15 & 7,77 & 7,41 & 7,07 & 6,74 & 6,43 & 6,13 & 5,84 \\
\hline Descontado e Acumulado & 807,63 & 816,18 & 824,33 & 832,10 & 839,51 & 846,58 & 853,32 & 859,74 & 865,87 & 871,71 \\
\hline
\end{tabular}

